\title{
METODE LANGSUNG (DIRECT METHOD) DALAM PENGAJARAN BAHASA ARAB
}

\author{
Muhammad Ali Bakri \\ Dosen Program Studi Ahwal as-syakhsiah Fakultas Agama Islam \\ Universitas Muhammadiyah Makassar
}

\begin{abstract}
Direct means straight to the point. Direct method or straight to the point method is the way in presenting Arabic where the teacher directly uses the language (Arabic) as the language in giving instruction, without using students' mother tongue. If there is a word is difficult to understand by the students, teachers can interpret that word by using props, demonstrating, describing and etc. This method is based on the understanding that teaching foreign language subject is not the same as teaching the science subject. If in the Learning science, the students are required to memorize certain formulas, think and remember, in language teaching, students or pupil are trained to practice directly spelling certain words or sentences. It is same when we consider a mother in teaching language to her childrens, she practices the language by herself directly, lead her child to pronounce the word by -word, sentence by-sentence, and her children will repeat what she spell in funny way. In principle, Direct method is really important in teaching Arabic, because through this method students can practice their speaking skills directly without using their mother tongue (the language of their scope). Although in the first time it seems difficult for students to duplicate it, but this method finally so interesting for them .
\end{abstract}

\section{Keywords: Direct method, Arabic language}

\begin{abstract}
Abstrak
Direct artinya langsung. Direct method atau metode langsung yaitu suatu cara menyajikan materi pelajaran Bahasa Arab di mana guru langsung menggunakan Bahasa tersebut sebagai bahasa pengantar, dan tanpa menggunakan bahasa anak didik sedikitpun dalam mengajar. Jika ada suatu kata-kata yang sulit dimengerti anak didik, guru dapat mengartikan dengan menggunakan alat peraga, mendemonstrasikan, menggambarkan dan lain-lain. Metode ini berpijak dari pemahaman, pengajarkan bahasa asing tidak sama halnya sama mengajar ilmu pasti atau ilmu alam. Jika mengajar ilmu pasti, siswa dituntut agar dapat menghafal rumus-rumus tertentu, berfikir dan mengingat, dalam pengajaran bahasa, siswa atau anak didik dilatih praktik langsung mengucapkan kata-kata atau kalimat-kalimat tertentu. Demikianlah halnya kalau kita perhatikan seorang ibu mengajarkan bahasa kepada anak-anaknya mula-mula dengan melatih anak-anaknya langsung dengan mengajarinya menuntunnya mengucapkan kata per-kata, kalimat per-kalimat dan anaknya menurutinya meskipun dilihat terasa lucu. Pada prinsipnya, metode langsung (direct method) ini sangat utama dalam mengajar bahasa Arab, karena melalui metode ini siswa langsung dapat melatih kemahiran lidah tanpa menggunakan bahasa ibu (bahasa lingkungannya). Meskipun pada mulanya terlihat sulit anak didik untuk menirukannya, tetapi metode ini menarik bagi anak didik.
\end{abstract}

Kata kunci: Metode Langsung, bahasa arab 


\section{PENDAHULUAN}

$\mathrm{P}$ endidikan merupakan merupakan usaha sadar seseorang dalam rangka mentransfer pengalaman, pengetahuan, kecakapan, dan kemampuan kepada orang lain. Pendidikan sudah tentu memiliki tujuan, yaitu untuk membuat orang yang dididik mampu melakukan fungsi hidupnya dalam pergaulan bersama dengan sebaik-baiknya. ${ }^{1}$

Dalam upayanya mencapai tujuan, pendidikan memerlukan proses, maka salah satu prosesnya adalah pengajaran atau pembelajaran. ${ }^{2}$ Dengan kata lain, pengajaran merupakan metode dalam pendidikan secara umum. Sementara itu, pengajaran itu sendiri memiliki tujuan khusus. Oleh karena itu, proses pelaksanaan pengajaran dalam bidang ilmu apapun termasuk dalam bidang bahasa juga memiliki metode.

Metode pengajaran ialah cara yang digunakan guru dalam mengadakan hubungan dengan siswa pada saaat berlangsungnya pengajaran. Metode pengajaran berperan sebagai alat untuk menciptakan poses mengajar dan belajar. Dengan metode ini, diharapkan tumbuh berbagai kegiatan belajar siswa sehubungan dengan kegiatan mengajar guru. Dengan kata lain, terciptalah interaksi edukatif. Metode pengajaran bahasa tentu bertujuan agar bahasa yang diajarkan dapat diketahui oleh peserta

${ }^{1}$ Tri Prasetya, Filsafat Pendidikan untuk IAIN, STAIN, PTAIS (Cet. II; Bandung: Pustaka Setia, 2002), hlm. 13 dan 15.

${ }^{2}$ Abd. Hlm.im Soebahar, Wawasan Baru Pendidikan Islam (Cet I; Jakarta: Kalam Mulia, 2002), hlm. 8-9. didik. ${ }^{3}$ Metode mengajar yang baik adalah metode yang dapat menumbuhkan kegiatan belajar siswa. ${ }^{4}$

Metode adalah langkah-langkah umum tentang penerapan teori-teori yang ada pada pendekatan tertentu. ${ }^{5}$ Dalam tingkatan ini, diadakan pilihan-pilihan tentang keterampilan-keterampilan khusus mana yang harus diajarkan, materi-materi apa yang harus disampaikan, dan bagaimana urutannya.

Terlihat di sini bahwa metode jauh lebih operasional dibandingkan dengan pendekatan, sebab metode sudah menginjak ke tingkat pelaksanaan lapangan. Bentuk metode yang digunakan dalam pengajaran bahasa di lapangan tidak boleh bertentangan dengan pendekatan, tetapi harus mendukung anggapananggapan yang ada dalam pendekatan. ${ }^{6}$

Metode pengajaran telah mengalami perbaikan jauh lebih banyak di dalam beberapa periode sejarah pendidikan dari pada yang lainnya. ${ }^{7}$ Metode pengajaran

${ }^{3}$ Nana Sudjana dalam Syamsul Nizar (Editor), Sejarah Pendidikan Islam: Menelusuri Jejak Sejarah Era Rasulullah Sampai Indonesia (Cet. I; Jakarta: Kencana Prenada Group, 2007), hlm. 16.

${ }^{4}$ Nana Sudjana dalam Syamsul Nizar (Editor), Sejarah Pendidikan Islam: Menelusuri Jejak Sejarah Era Rasulullah Sampai Indonesia, hlm. 16.

${ }^{5}$ Pendekatan pembelajaran (madkhlm. altadri>s/ teaching approach) adalah tingkat pendirian filosofis mengenai bahasa, belajar, dan mengajar bahasa. Pendekatan merupakan pendirian filosofis yang selanjutnya menjadi acuan dalam kegiatan belajar dan mengajar bahasa. Acep Hermawan, Metodologi Pembelajaran Bahasa Arab (Cet. I; Bandung: PT Remaja Rosdakarya, 2011), hlm. 167.

${ }^{6}$ Acep Hermawan, Metodologi Pembelajaran Bahasa Arab , hlm. 168.

${ }^{7}$ Tri Prasetya, Filsafat Pendidikan untuk IAIN, STAIN, PTAIS, hlm. 15. 
bahasa dapat dimasukkan dalam upaya perbaikan tersebut, dengan pertimbangan bahwa dalam sejarah pengajaran bahasa terdapat ragam metode yang dirumuskan dan telah dipergunakan. Hal tersebut bertujuan agar bahasa dapat dengan mudah diajarkan dan dipahami, sehingga kemahiran dalam berbahasa pun dapat terwujud.

Metode apapun yang digunakan dalam pengajaran, akan bermuara pada pencapaian tujuan pengajaran. Adapun tujuan utama pembelajaran bahasa asing adalah pengembangan kemampuan pelajar dalam penggunakan bahasa itu, baik lisan maupun tulis. Kemampuan menggunakan bahasa dalam dunia pengajaran bahasa disebut keterampilan berbahasa (mahärät al-lugah). Keterampilan tersebut ada empat, yaitu keterampilan menyimak (mahārah al-istimā'l listening skill), berbicara (mahārah al-kalām speaking skill), membaca (mahārah al-qirā'ah/ reading skill), dan menulis (mahārah alkitābah / writing skill). ${ }^{8}$

Seperti disinggung sebelumnya bahwa metode pengajaran sudah mengalami perkembangan selama kurun sejarah pendidikan, metode pengajaran bahasa Arab pun ikut mengalami perubahan dan perkembangan tersebut.

Di antara metode-metode dalam pengajaran bahasa Arab adalah metode langsung atau direct method. Munculnya

\footnotetext{
${ }^{8}$ Keterampilan menyimak dan membaca dikategorikan ke dalam keterampilan reseptif (almaha>rah al-istiqba>liyyah/receptive skill), sedangkan keterampilan berbicara dan menulis dikategorikan ke dalam keterampilan produktif (almaha>rah al-inta>jiyyah/productive skill). Acep Hermawan, Metodologi Pembelajaran Bahasa Arab, hlm. 129.
}

metode langsung dalam pembelajaran bahasa Arab tentu tidak lepas dari periodisasi perkembangan pangajaran atau pembelajaran bahasa kedua -termasuk bahasa Arab- itu sendiri.

Sejarah pengajaran bahasa kedua secara umum- dimulai dengan model private, karena pada masa lalu hanya orang-orang terkemuka dan para bangsawan saja yang mampu belajar bahasa kedua. Pada permulaan masa imperium Romawi, peradaban Yunani Kuno masih sangat dominan, maka dalam rangka menguasai ilmu dan peradaban Yunani Kuno itu, para penguasa Romawi merasa perlu mempelajari bahasa Yunani. ${ }^{9}$

Kenyataan ini menunjukkan betapa kemajuan ilmu pengetahuan dan peradaban menjadikan posisi bahasa sebuah negara kuat di mata negara lain, maka eksistensi dan perkembangan bahasa dapat menjadi cerminan kemajuan ilmu dan peradaban sebuah bangsa.

Seiring dengan menguatnya kekuasaan Romawi, maka bahasa Latin menjadi bahasa yang paling dominan, karena digunakan sebagai bahasa agama, ilmu, sastra dan politik. ${ }^{10}$

Lahirnya alat percetakan pada abad 15 M membawa perubahan besar pada pengajaran bahasa Arab, hingga di Eropa, bahasa Latin menjadi bahasa sekolah atau bahasa ilmu. Pada waktu itu ada upaya dari para ahli filsafat bahasa untuk menerapkan kaidah-kaidah gramatika yang diambil dari bahasa tulis Latin kuno pada

\footnotetext{
${ }^{9}$ Ahmad Fuad Effendi, Metodologi Pengajaran Bahasa Arab (Cet. III; Malang: Misykat, 2005), hlm. 17.

10 ibid, hlm. 17.
} 
bahasa lisan. Maka pengajaran bahasa pada waktu itu berkutat pada menghafalkan kaidah-kaidah bahasa dan penerapannya secara ketat dalam ujaranujaran. ${ }^{11}$ Nampaknya, fakta sejarah inilah yang dianggap sebagai cikal bakal metode yang kemudian dikenal dengan "gramatika-terjemah".

Pada abad yang juga disebut-sebut sebagai abad kebangkitan Eropa ini, banyak sekolah dan universitas di Eropa mengharuskan pelajar dan mahasiswanya belajar bahasa Latin karena dianggap mempunyai nilai pendidikan yang tinggi guna mempelajari teks-teks klasik. Para guru bahsa pada zaman itu berpandangan bahwa dengan latihan menerjemahkan, dua hal dapat diperoleh sekaligus, yakni pengenalan rasa bahasa dan penguasaan tata bahasa. $^{12}$

Pada abad $17 \mathrm{M}$, seorang pendidik dari Cheko, Jhon Amos Comenius, dalam bukunya "Membuka Khazanah Bahasa" yang terbit pada tahun 1630, mengemukakan pandangan yang menghebokan dengan pernyataannya bahwa metode pengajaran bahasa yang selama ini dipakai tidak berguna. Dalam pandangannya, menguasai kaidah-kaidah saja dan menghafalkan kosa kata lepas adalah sia-sia, dan bahwa upaya dalam menundukkan kaidah bahasa kepada prinsip-prinsip logika adalah bertentangan dengan tabiat bahasa yang spontan. Ia menyarankan cara belajar bahasa melalui gerakan dan aktivitas yang langsung menyertai ungkapan bahasa, atau melalui

\footnotetext{
${ }^{11}$ Ibid, hlm. 18.

${ }^{12}$ Bambang Kaswanti Purwo, Pragmatik dan Pengajaran Bahasa (Yogyakarta: Kanisius, 1990), hlm. 43.
}

gambar-gambar yang konkrit, tanpa terlalu dibebani dengan penguasaan kaidahkaidah. Pandangan ini mendapat dukukungan dari Jhon Lock. ${ }^{13}$

Pada awal abad 19 M, muncul pandangan yang menguatkan kembali perlunya penguasaan kaidah-kaidah bahasa dan kosa kata dalam pengajaran bahasa. Pelopornya adalah seorang pendidik dari Jerman, Karl Ploetz, yang menyarankan pemilihan teks-teks tertentu untuk diterjemahkan ke dan dari bahasa pertama. Metode yang kemudian dikenal dengan nama "metode gramatikaterjemah" ini, tersebar luas pemakaiannya di Eropa Barat ketika itu. ${ }^{14}$

Pada pertengahan abad 19, muncul metode baru yang dipelopori oleh Francois Gouin dari Prancis. Metode yang kemudian dikenal sebagai "metode langsung" itu membawa siswa terjun langsung dan tenggelam dalam aktivitas bahasa asing yang dipelajarinya sejak detik pertama dalam ruang kelas. Metode ini memberikan penekanan pada penggunaan bahasa secara fungsional dan mengesampingkan hafalan kaidah-kaidah gramatika. Metode ini digunakan secara luas di benua Eropa, Amerika, Timur Tengah, dan belahan dunia lainnya sampai perempat pertama abad ke-20. ${ }^{15}$

Pembelajaran bahasa Arab bagi non Arab dimulai dari pertama kali pada abad ke-17, ketika bahasa Arab mulai diajarkan di Universitas Cambridge Inggris. Sementara di Amerika, perhatian terhadap

\footnotetext{
${ }^{13}$ Ahmad Fuad Effendi, Metodologi Pengajaran Bahasa Arab, hlm. 18.

${ }^{14}$ Ibid, hlm. 18.

${ }^{15}$ ibid, hlm. 18-19.
} 
bahasa Arab dan pembelajarannya baru dimulai pada tahun 1947 di sekolahsekolah tentara Amerika. Di Mesir, terdapat banyak pusat pembelajaran bahasa Arab, ditandai dengan banyaknya proyek pengembangan bahasa Arab. Pada setiap pusat-pusat pembelajaran bahasa ini, dipastikan ada proyek pengembangan bahasa Arab lengkap dengan tujuan-tujuan khusus, sejumlah perencanaan dan materimaterinya. ${ }^{16}$

Hal itu bisa terjadi setelah bahasa Arab melalui masa yang cukup panjang seiring dengan pasang surutnya pengaruh bangsa Arab dan Islam, yaitu sejak sejarah mencatat bahwa bahasa Arab mulai menyebar keluar jazirah Arab sejak abad ke-1 $\mathrm{H}$ atau abad ke-7 M, sampai masa kebangkitan kembali yang ditandai dengan invansi Napoleon Bonaparte ke Mesir pada tahun 1798. Sejak saat itu, Mesir banyak mengadakan hubungan dengan kebudayaan Eropa, khususnya Prancis. Dimulai dengan upaya alih-ilmu Eropa modern ke Mesir dan Syam, terutama dalam bidang administrasi, pendidikan, dan ketentaraan. Dalam pengajaran bahasa Arab, metode-metode yang berkembang di Eropa pun diadopsi dan digunakan secara luas di Mesir, mulai dari metode gramatika-terjemah sampai dengan metode langsung. ${ }^{17}$

\footnotetext{
${ }^{16}$ Banyak alasan non Arab belajar bahasa Arab, di antaranya: a) Motivasi agama, terutama Islam karena bahasa Arab harus dipelajari sebagai alat untuk memahami ajaran agama yang bersumber dari al-Qur'an, b) Orang non Arab merasa asing jika berkunjung ke Jazirah Arab, c) Banyak karya ulama klasik, bahkan yang berkembang dewasa ini menggunkan bahasa Arab. Lihat Acep Hermawan, Metodologi Pembelajaran Bahasa Arab, hlm. 99.

${ }^{17}$ Dari uraian tersebut, dapat dikatakan bahwa perkembangan metodologi pengajaran bahasa Arab berjalan seiring dengan perkembangan yang terjadi
}

Dari sini, nampak sangat jelas bahwa metode langsung dalam pengajaran atau pembelajaran bahasa Arab merupakan metode pengembangan dari metode sebelumnya, yaitu metode gramatikaterjemah.

\section{B. Rumusan Masalah}

Di antara metode dalam pengajaran bahasa Arab adalah metode langsung atau direct method. Metode inilah yang menjadi topik pembahasan makalah ini dengan masalah pokok bagaimana penggunaan metode langsung dalam pembelajaran bahasa Arab? Masalah pokok ini dirumuskan dalam sub masalah sebagai berikut:

1. Bagaimana pengertian, pembagian, dan ciri-ciri metode langsung dalam pengajaran bahasa Arab?

2. Bagaimana penerapan metode langsung dalam pengajaran bahasa Arab?

3. Bagaimana penilaian terhadap penerapan metode langsung dalam pengajaran bahasa Arab?

\section{PEMBAHASAN}

\section{A. Pengertian, Pembagian dan Ciri- ciri Metode Langsung dalam Pengajaran Bahasa Arab}

\section{Pengertian Metode Langsung}

Metode langsung adalah terjemahan dari bahasa Inggris direct method, sementara dalam bahasa Arab disebut altarīqah al-mubāsyarah. Metode ini menurut Azhar Arsyad, muncul sebagai

dalam pengajaran bahasa-bahasa Latin di Eropa, dan bahasa Inggris di Eropa dan Amerika. Lihat Ahmad Fuad Effendi, Metodologi Pengajaran Bahasa Arab, hlm. 20-21. 
reaksi penolakan terhadap metode alqawā'id wa al-tarjamah yang diklaim memperlakukan bahasa sebagai benda mati dan tak punya unsur hidup. Pada saat yang sama muncul gerakan yang mempropagandakan untuk menjadikan bahasa asing lebih efektif dan efisien. ${ }^{18}$

Metode langsung berasumsi bahwa proses belajar bahasa asing sama dengan belajar bahasa ibu, yaitu dengan menggunakannya secara langsung dan intensif dalam komunikasi. Menurut metode ini, para pelajar belajar bahasa asing dengan cara menyimak dan berbicara, sedangkan membaca dan menulis dapat dikembangkan kemudian. ${ }^{19}$

Metode ini disebut metode langsung karena selama pelajaran, guru langsung menggunakan bahasa asing yang diajarkan (dalam hal ini bahasa Arab), sedangkan bahasa murid tidak boleh digunakan. Untuk menjelaskan arti suatu kata atau kalimat digunakan gambar-gambar atau peragaan. ${ }^{20}$

\section{Pembagian Metode Langsung}

Ada tiga metode yang sangat melekat dengan metode ini, bahkan merupakan bagian berkesinambungan dalam metode langsung, yaitu:

a. Metode psikologi (al-taríqah alsīkūlüjiyyah/ psychological method) yang mendasarkan proses

\footnotetext{
${ }^{18}$ Azhar Arsyad, Madkhl ilā Țuruq Ta'Tim alLugah al-'arabiyyah li Mudarrisi al-Lugah al'Arabiyyah (Cet. I; Ujung Pandang: Penerbit AHKAM, 1998), hlm. 48.

${ }^{19}$ Acep Hermawan, Metodologi Pembelajaran Bahasa Arab, hlm. 176-177.

${ }^{20}$ Muljanto Sumardi, Pengajaran Bahasa Asing; Sebuah Tinjauan dari Segi Metodologi (Cet. II; Jakarta: Bulan Bintang, 1975), hlm. 32-33.
}

pembelajarannya atas pengamatan perkembangan mental dan asosiasi pikiran.

b. Metode fonetik (al-tariqah alsautiyyahl phonetic method), yaitu menulis materi dalam nitasi fonetik, bukan ejaan seperti yang lazim digunakan. Dalam prakteknya, metode ini mengawali proses pembelajaran dengan latihan pendengaran terhadap bunyi.

c. Metode alamiah (al-tariqah altabi'iyyah/ natural method) yang merupakan kelanjutan metode fonetik. Metode ini menyamakan cara belajar bahasa asing dengan bahasa ibu yang biasanya didasarkan pada prilaku atau kebiasaan sehari-hari yang berlangsung secara alamiah. ${ }^{21}$

Pada prinsipnya ketiga cabang ini tidak ada perbedaan. Ketiganya memiliki titik tekan dalam penggunaan bahasa Asing yang dipelajari secara langsung dalam proses belajar mengajar, maka penggunaan bahasa ibu atau bahasa kedua sedapat mungkin dihindari.

3. Ciri-ciri Metode Langsung.

Metode langsung ini memiliki ciri utama yang membedakannya dengan metode lainnya, yaitu:

a. Metode ini mengutamakan kemahiran menyimak dan berbicara dari kemahiran membaca dan menulis.

b. Menghindari penggunaan terjemahan, sebaliknya lebih mengutamakan ungkapan bahasa target.

c. Mengeliminir bahasa ibu.

\footnotetext{
${ }^{21}$ Acep Hermawan, Metodologi Pembelajaran Bahasa Arab, hlm. 179-180.
} 
d. Menggunakan tehnik "al-taqlid wa alhifzl" atau mengikuti/ menirukan dalam mengucapkan kalimat-kalimat atau ungkapan-ungkapan dialog dan kemudian menghafalkannya. ${ }^{22}$

e. Materi pelajaran terdiri dari kata-kata dan struktur kalimat yang banyak digunakan sehari-hari.

f. Gramatika diajarkan dengan melalui situasi dan dilakukan secara lisan bukan dengan cara menghafalkan aturan-aturan gramatika.

g. Sejak permulaan, murid dilatih untuk "berfikir dalam bahasa asing.,"23

\section{Contoh Materi}

Contoh dibawah ini dikutip dari buku Durus al-Lughah al-Arabiyah Jilid Satu, oleh Imam Zarkasyi dan Imam Syubani yang dipakai di Pondok Modern Gontor.

\begin{tabular}{|c|c|c|}
\hline تلك سبّّورة & هذه مسـطرة & ما هذه؟ \\
\hline تلك نافذة & هذه طالاّسـة & ما هذه؟ \\
\hline تلك منششّة & هذه كرّاسـة & ما هذه؟ \\
\hline تلك كرّاسـة & هذه كرّاسـة & ما هذه؟ \\
\hline تلك ممححاة & هذه ممححاة & ما هذه؟ \\
\hline تلك سبّّورة & هذه سبّّورة & ما هذه؟ \\
\hline
\end{tabular}

\begin{tabular}{|c|c|}
\hline نعم، هذه منشّــة & أهذه منشّــة ؟ \\
\hline نعم، هذه نافذة & أهذه نافذة؟ \\
\hline
\end{tabular}

Sebagaimana disebutkan dimuka, dalam metode langsung penggunaan bahasa ibu sangat dihindari. Oleh karena itu, materi disusun sedemikian rupa sehingga memungkinkan guru melakukan paragaan dan penunjukan langsung benda asli, gambar atau model (tiruan benda) ketika mengenalkan mufradat dan struktur kalimat yang baru.

Dalam metode ini, untuk tingkat pemula, nahwu tidak diajarkan secara khusus, tapi melalui apa yang disebut dengan al-nahwu al-wazhifi (nahwu fungsional) seperti dalam contoh berikut (dicuplik dari buku yang sama).

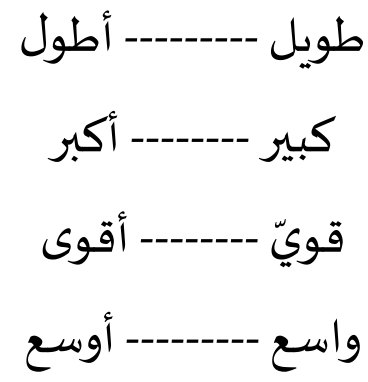

Dalam contoh diatas, materi nahwu mengenai isim tafdhil tidak dijelaskan definisinya atau cara-cara pembentukannya, tapi langsung pada contoh-contoh dan dilatihkan pemakaiannya dalam kalimat. Pada tingkat berikutnya (pra-menengah atau

${ }^{22}$ Acep Hermawan, Metodologi Pembelajaran Bahasa Arab, hlm. 49-50.

${ }^{23}$ Muljanto Sumardi, Pengajaran Bahasa Asing; Sebuah Tinjauan dari Segi Metodologi, hlm. 33.

menengah), qawaid bisa diajarkan berdiri sendiri sebagai sebuah mata pelajaran tapi dengan cara induktif, yaitu dimulai dengan contoh-contoh penjelasan, kemudian 
kesimpulan kaidah, dan diakhiri dengan latihan-latihan. Salah satu buku yang banyak digunakan adalah al-Nahwu alWadhih oleh Ali al-Jarim dan Musthafa Amin terbitan Dar-al-Ma'arif Kairo.

\section{B. Langkah Penerapan Metode Langsung dalam Pengajaran Bahasa Arab}

Adapun langkah penerapan metode ini adalah: ${ }^{24}$

1. Pendahuluan, memuat berbagai hal yang berkaitan dengan materi yang akan disajikan baik berupa appersepsi, atau tes awal tentang materi, atau lainnya.

2. Guru memberikan materi berupa dialog-dialog pendek yang rilek, dengan bahasa yang biasanya digunakan sehari-hari secara berulangulang. Guru memulai penyajian materi secara lisan, mengucapkan satu kata dengan menunjuk bendanya atau gambar benda, memeragakan sebuah gerakan atau mimik wajah, dan isyaratisyarat. Pelajar menirukan berkali-kali sampai benar pelafalannya dan faham maknanya.

3. Pelajar diarahkan untuk disiplin menyimak dialog-dialog tersebut, lalu menirukan dialog-dialog yang disajikan sampai lancar.

Jika pada langkah ini, siswa dipandang sudah menguasai materi, baik pelafalan maupun maknanya, guru juga dapat meminta siswa membuka buku teks, kemudian memberikan contoh bacaan yang benar dan

\footnotetext{
${ }^{24}$ Acep Hermawan, Metodologi Pembelajaran Bahasa Arab, hlm. 181. Lihat juga Ahmad Fuad Effendi, Metodologi Pengajaran Bahasa Arab, hlm. 37.
}

berikutnya siswa diminta membaca secara bergantian.

4. Para pelajar dibimbing menerapkan dialog-dialog itu dengan temantemannya secara bergiliran. Pelajar yang sudah maju diberi kesempatan untuk mengadakan dialog lain yang dianalogikan dengan contoh yang diberikan oleh guru. Jika pada langkah ini siswa diberi bacaan, maka berikutnya adalah menjawab secara lisan pertanyaan atau latihan yang ada dalam bacaan dilanjutkan dengan mengerjakannya secara tertulis.

5. Struktur atau tata bahasa diberikan bukan dengan menganalisa nahwu, melainkan dengan memberikan contohcontoh secara lisan yang sedapat memungkin menarik perhatian pelajar untuk mengambil kesimpulankesimpulan sendiri.

6. Sebagai penutup, jika diperlukan, evaluasi akhir berupa pertanyaanpertanyaan dialog yang harus dijawab oleh pelajar sebagaimana pola-pola yang sudah dibuat.

Selain itu metode ini bisa dilakukan melalui langkah-langkah berikut ini:

1. Guru memulai penyajian materi secara lisan, mengucapkan satu kata dengan menunjuk bendanya atau gambar benda itu. Siswa menirukan berkalikali sampai benar pelafalannya dan faham maknanya.

2. Latihan selanjutnya berupa Tanya jawab dengan kata Tanya "ma, hal, aina, limadza" dan lain-lain sesuai dengan tingkat kesulitan siswa. Model interaksi bervariasi, bisa dimulai dengan klasikal, kemudian kelompok, dan kahirnya individual. 
3. Setelah guru yakin bahwa siswa menguasai materi yang disajikan, maka siswa diminta untuk membuka buku teks. Guru memberikan contoh bacaan yang benar kemudian siswa diminta membaca secara bergantian.

4. Kegiatan berikutnya adalah menjawab pertanyaan secara lisan atau latihan yang ada di dalam buku, dilanjutkan dengan mengerjakannya secara tertulis.

5. Bacaan umum yang sesuai dengan tingkatan siswa diberikan sebagai materi tambahan, seperti cerita humor, cerita yang mengandung hukmah, peribahasa dan lain-lain yang bisa menarik perhatian siswa. ${ }^{25}$

Penggunaan langkah-langkah ini selanjutnya diserahkan kepada pengajar sesuai situasi dan kondisi, dengan catatan tidak bertentangan dengan konsep dasar dan karakteristik metode ini.

\section{Penilaian terhadap Metode} Langsung terhadap Penguasaan Bahasa Arab

Penilaian merupakan satu kemestian untuk dilakukan dalam rangka memperbaiki kualitas. Karenanya, dalam proses pembelajaran selalu ada penilaian yang disebut dengan evaluasi. Penilaian dalam hal ini dilakukan dalam upaya perbaikan dan pengembangan hasil dan pencapaian tujuan secara maksimal. Penilaian tidak saja diperuntukkan untuk hasil kerja anak didik tetapi perlu juga menilai kinerja pendidiknya, terutama yang terkait dengan metode yang dipilihnya dalam proses edukasi.

${ }^{25}$ Syamsuddin Asyrofi dkk. 2006. Metodologi Pembelajaran Bahasa Arab. Hlm. 104
Jika kita masih berpegang pada pepatah "tak ada gading yang tak retak", maka dapat disimpulkan bahwa semua metode yang dipilih sebagai upaya mencapai tujuan pembelajaran termasuk pembelajaran bahasa Arab, memiliki kekurangan atau kelemahan di balik segala kekuatan yang dimilikinya.

Metode langsung sebagai salah satu metode dalam pembelajaran bahasa Arab termasuk memiliki kekuatan sekaligus kelemahan berdasarkan penilaian pakar pendidikan bahasa.

Keunggulan-keunggulan metode ini dapat dicatat sebagai berikut: ${ }^{26}$

1. Membangkitkan semangat para guru bahasa Arab untuk menggunakan bahasa Arab sebagai akal komunikasi yang dapat membantu tercapainya keterampilan menyimak (mahārah alistimā) dan keterampilan berbicara (mahārah al-kalām) siswa.

2. Memotivasi siswa untuk senantiasa berpikir tentang bahasa Arab sehingga tidak terjadi pencampuran dengan bahasa ibu.

3. Merupakan tahap awal dalam pembelajaran dengan hiwär dan kisah yang dapat menjadi asas dalam pencapaian mahärah lugawiyyah yang lain.

4. Memotivasi siswa untuk dapat menyebutkan dan mengerti kata-kata dan kalimat dalam bahasa asing yang diajarkan, apalagi dengan bantuan alat peraga.

\footnotetext{
${ }^{26}$ Ahmad Fuad Effendi, Metodologi Pengajaran Bahasa Arab, hlm. 38. Lihat juga Acep Hermawan, Metodologi Pembelajaran Bahasa Arab, hlm. 182-183.
} 
5. Memudahkan siswa menangkap simbol-simbol bahasa asing dengan kata-kata sederhana dan bahasa sehari-hari.

6. Menggunakan berbagai macam alat peraga yang menarik minat siswa.

7. Memberikan siswa pengalaman langsung dan praktis, sekalipun mungkin kalimat yang diucapkan belum dipahami sepenuhnya.

8. Melatih alat ucap siswa dengan sering mendengar dan mengucapkan katakata dan kalimat.

Adapun beberapa hal yang dikategorikan sebagai kekurangan metode ini adalah sebagai berikut:

1. Pelajar lemah dalam kemampuan membaca atau lemah dalam memahami teks.

2. Tidak bisa dilaksanakan dalam kelas besar.

3. Banyak waktu terbuang dalam mengulang-ulang makna satu kata dan memungkinkan adanya salah persepsi siswa.

4. Bisa membosankan karena siswa dibebani menghafal. ${ }^{27}$

5. Model latihan menirukan dan menghafalkan kalimat-kalimat yang seringkali tidak bermakna atau tidak realistis bisa membosankan bagi orang dewasa.

6. Metode ini juga dikritik oleh para ahli dari segala kelemahan teoritisnya yang menyamakan antara pemerolehan bahasa pertama dengan pembelajaran bahasa kedua/asing. ${ }^{28}$

\footnotetext{
${ }^{27}$ Acep Hermawan, Metodologi Pembelajaran Bahasa Arab, hlm. 182-183.

${ }^{28}$ Syamsuddin Asyrofi dkk. 2006. Metodologi Pembelajaran Bahasa Arab. HIm. 106
}

Menurut hemat penulis, hal-hal yang dianggap lemah dalam metode langsung tersebut bukanlah kelemahan fatal yang tidak bisa ditolerir. Kelemahan-kelemahan tersebut sangat memungkinkan diatasi dengan memperbaiki teknik tertentu sesuai konteksnya.

\section{PENUTUP}

1. Metode langsung dalam pengajaran bahasa Arab merupakan counter dari metode sebelumnya, yaitu metode gramatika-terjemah. Metode tersebut diklaim sebagai metode tertua, karena itu metode langsung merupakan metode kedua tertua dari metode pengajaran bahasa Arab. Sekalipun demikian, metode ini, sampai pada zaman modern sekarang ini masih memiliki tempat di berbagai institusi pembelajaran bahasa Arab. Bahkan metode inilah yang paling banyak dikenal dan banyak menimbulkan pertentangan pendapat.

2. Penerapan metode langsung dalam pengajaran bahasa Arab meliputi tiga langkah utama, yaitu: pertama, pendahuluan yang diawali oleh guru yang memuat berbagai hal yang terkait dengan materi yang akan disajikan, kedua, pelajar diarahkan untuk disiplin menyimak kata-kata atau dialog-dialog yang diberikan, lalu menirukannya sampai lancar, seyogyanya bersifat rileks dan menarik perhatian siswa, dan ketiga, penutup yang diisi dengan evaluasi akhir berupa pertanyaanpertanyaan dialog yang harus dijawab oleh pelajar, baik secara individual atau kelompok secara atraktif. 
3. Metode langsung dalam pembelajaran bahasa Arab memiliki kekuatan dan kekurangan, tetapi jika kelemahan itu dapat diatasi tanpa menghilangkan ciri khasnya, metode ini dinilai masih layak untuk dipertahankan.

4. Metode langsung dalam pengajaran bahasa Arab merupakan counter dari metode sebelumnya, yaitu metode gramatika-terjemah. Metode tersebut diklaim sebagai metode tertua, karena itu metode langsung merupakan metode kedua tertua dari metode pengajaran bahasa Arab. Sekalipun demikian, metode ini, sampai pada zaman modern sekarang ini masih memiliki tempat di berbagai institusi pembelajaran bahasa Arab. Bahkan metode inilah yang paling banyak dikenal dan banyak menimbulkan pertentangan pendapat.

5. Penerapan metode langsung dalam pengajaran bahasa Arab meliputi tiga langkah utama, yaitu: pertama, pendahuluan yang diawali oleh guru yang memuat berbagai hal yang terkait dengan materi yang akan disajikan, kedua, pelajar diarahkan untuk disiplin menyimak kata-kata atau dialog-dialog yang diberikan, lalu menirukannya sampai lancar, seyogyanya bersifat rileks dan menarik perhatian siswa, dan ketiga, penutup yang diisi dengan evaluasi akhir berupa pertanyaanpertanyaan dialog yang harus dijawab oleh pelajar, baik secara individual atau kelompok secara atraktif.

6. Metode langsung dalam pembelajaran bahasa Arab memiliki kekuatan dan kekurangan, tetapi jika kelemahan itu dapat diatasi tanpa menghilangkan ciri khasnya, metode ini dinilai masih layak untuk dipertahankan.

\section{DAFTAR PUSTAKA}

Arsyad, Azhar. 1998. Madkhal ilā Turuq Ta'Tim al-Lugah al-“arabiyyah li Mudarrisi al-Lugah al-'Arabiyyah. Cet. I; Ujung Pandang: Penerbit AHKAM.

Effendi, Ahmad Fuad. 2005. Metodologi Pengajaran Bahasa Arab. Cet. III; Malang: Misykat.

Hermawan, Acep. 2011. Metodologi Pembelajaran Bahasa Arab. Cet. I; Bandung: PT Remaja Rosdakarya.

Prasetya, Tri. 2002. Filsafat Pendidikan untuk IAIN, STAIN, PTAIS. Cet. II; Bandung: Pustaka Setia.

Purwo, Bambang Kaswanti. 1990. Pragmatik dan Pengajaran Bahasa. Yogyakarta: Kanisius

Sudjana, Nana dalam Syamsul Nizar (Editor) 2007. Sejarah Pendidikan Islam: Menelusuri Jejak Sejarah Era Rasulullah Sampai Indonesia. Cet. I; Jakarta: Kencana Prenada Group.

Sumardi, Muljanto. 1975. Pengajaran Bahasa Asing; Sebuah Tinjauan dari Segi Metodologi. Cet. II; Jakarta: Bulan Bintang.

Syamsuddin Asyrofi dkk. 2006. Metodologi Pembelajaran Bahasa Arab. Yogyakarta: Pokja Akademik 
Volume 1. Nomor 1. Juni 2017| 12 


\title{
METODE CONTEXTUAL TEACHING AND LEARNING DALAM PEMBELAJARAN BAHASA ARAB
}

\author{
M. Ilham Muchtar \\ Dosen Program Studi Ahwal As-Syakhsiah Fakultas Agama Islam \\ Universitas Muhammadiyah Makassar
}

\begin{abstract}
The concept of Contextual Teaching and Learning (CTL) emphasizes on the student activity, both physically and mentally. Contextual Teaching and Learning believe that learning is not just about memorizing, , considering or remembering facts, demonstrating repetitious exercise but it is a process of experience in real life with the nature ( environment). Contextual Teaching and Learning in Arabic teaching and learning process is believed to improve student's achievement in learning Arabic because they will get so much eager to learn or they will have the confidence to know something that has not been known so the pupils are not depressed in teaching and learning process.
\end{abstract}

\section{Keywords: Activities, Contextual Teaching and Learning (CTL), Achievement}

\begin{abstract}
Abstrak
Konsep pembelajaran Contextual Teaching and Learning (CTL) menekankan pada aktivitas siswa secara penuh, baik fisik maupun mental. Contextual Teaching and Learning memandang bahwa belajar bukanlah kegiatan menghafal, mengingat fakta-fakta, mendemonstrasikan latihan secara berulang-ulang semata akan tetapi proses berpengalaman dalam kehidupan nyata di alam terbuka. Contextual Teaching and Learning dalam pembelajaran bahasa Arab diyakini dapat meningkatkan prestasi belajar siswa dalam belajar bahasa Arab karena peserta didik semakin bersemangat belajar ataupun mempunyai kepercayaan diri untuk mengetahui sesuatu yang belum diketahui sehingga membuat peserta didik tidak tertekan dalam proses belajar mengajar.
\end{abstract}

Kata Kunci: Aktifitas, Contextual Teaching and Learning (CTL), Prestasi. 


\section{PENDAHULUAN}

$\mathrm{P}$ embelajaran pada Pembelajaran pada hakikatnya adalah proses interaksi antara peserta didik dengan lingkungannya, sehingga terjadi perubahan perilaku ke arah yang lebih baik. Dalam interaksi tersebut banyak sekali faktor internal yang datang dari dalam diri individu, maupun faktor eksternal yang datang dari lingkungan. Metode atau model mengajar merupakan salah satu cara yang dipergunakan seorang pendidik dalam menjalin hubungan dengan peserta didiknya (siswa) pada saat berlangsungnya pengajaran, sehingga proses belajar mengajar yang tercipta tidak menempatkan pengajar sebagai satu-satunya sumber ilmu pengetahuan (teacher centered).

Setiap pengajar dituntut untuk selalu fokus pada proses penyajian materi. Karena itu seyogyanya seorang pengajar memiliki daya kreatifitas dalam mengajar dengan menggunakan segala macam metode dan pendekatan yang selaras dengan materi pelajaran yang diajarkan. Improvisasi model dan variasi metode dalam penyajian materi akan berdampak positif dengan meningkatnya minat peserta didik untuk belajar, terlebih lagi dalam proses pembelajaran bahasa Arab.

Ahmad Zayadi dan Abdul Majid (2005: 8) mengatakan bahwa: Istilah pembelajaran, bermakna sebagai upaya untuk membelajarkan seseorang atau kelompok orang melalui berbagai upaya (effort) dan berbagai strategi, metode dan pendekatan ke arah pencapaian tujuan yang telah direncanakan.

Pendidik profesional mempunyai tugas ganda, selain sebagai pengajar juga sebagai pendidik. Proses belajar peserta didik sangat dipengaruhi oleh performance dan metode yang digunakan oleh pendidik dalam menyajikan suatu materi pelajaran. Pembelajaran yang berorientasi pada penguasaan materi dianggap gagal menghasilkan peserta didik yang aktif, kreatif, dan inovatif. Peserta didik hanya mampu mengingat materi pelajaran dalam jangka pendek akan tetapi lupa untuk mengimplementasikan substansi mata pelajaran dalam kehidupan sehari-hari. Peserta didik tidak memiliki kompetensi untuk memecahkan persoalannya dalam menghadapi situasi baru dengan kata lain materi pelajaran yang diterima di sekolah tidak dapat diterjemahkan dalam kehidupan keseharian karena hanya berorientasi pada hasil bukan pada proses pembelajaran.

Pendidik, sebagai motivator utama proses pembelajaran di sekolah cenderung menggunakan pola belajar konvensional-behaviorisme, yakni monoton dalam menyampaikan materi pelajaran sehingga yang terjadi hanya transfer ilmu pengetahuan semata, di mana peserta didik cenderung pasif dalam menerima informasi pelajaran. Pendidik juga tidak mampu memaksimalkan penggunaan media pembelajaran sebagai sarana penunjang dalam proses pengantar materi pelajaran. 
Akibatnya, peserta didik hanya mampu mengetahui materi pelajaran. Oleh karena itu perlu ada sebuah pendekatan pembelajaran bermakna yang fokus pada proses belajar bukan pada hasil belajar. Karena inti dari pembelajaran kontekstual adalah belajar untuk menemukan makna, maka terdapat paradigma khusus mengenai makna belajar dalam pembelajaran kontekstual.

Dalam konteks pembelajaran bahasa Arab di Indonesia, tampak bahwa metode yang diterapkan khususnya di tingkat sekolah menengah, masih merujuk kepada metode tradisional yang bergantung pada pengajaran kaidah-kaidah gramatikal bahasa Arab (Nahwu/Sharaf) (Azhar Arsyad, 2003:137), sehingga di satu sisi siswa memiliki kemampuan yang cukup baik dalam membaca dan memahami kitab-kitab kuning (buku klasik) tetapi di sisi lain ia masih lemah dalam berkomunikasi dengan bahasa Arab.

Salah satu model atau strategi pembelajaran yang mampu membuat seluruh siswa terlibat dalam suasana pembelajaran adalah melalui pendekatan kontekstual atau Contextual Teaching Learning (CTL). Sebagai sebuah strategi pembelajaran, dengan pendekatan kontekstual peserta didik tidak hanya menerima dan memahami penjelasan dari pengajar, tetapi ia juga dituntut untuk mengalami sendiri. Karena itu, model pembelajaran kontekstual dikembangkan dengan tujuan agar pembelajaran berjalan lebih produktif dan bermakna.

\section{A. METODE CONTEXTUAL TEACHING AND LEARNING (CTL)}

1. Pengertian Contextual Teaching And Learning (CTL)

Kata kontekstual (contextual) berasal dari kata context yang berarti "hubungan, konteks, suasana dan keadaan (konteks) " Sehingga Contextual Teaching and Learning (CTL) dapat diartikan sebagai suatu pembelajaran yang berhubungan dengan suasana tertentu. Secara umum contextual mengandung arti: relevan, ada hubungan atau kaitan langsung, mengikuti konteks; Yang membawa maksud, makna, dan kepentingan

Menurut Wina Sanjaya (2006: 109): Contextual Teaching and Learning (CTL) adalah suatu pendekatan pembelajaran yang menekankan kepada proses keterlibatan siswa secara penuh untuk dapat menemukan materi yang dipelajari dan menghubungkannya dengan situasi kehidupan nyata sehingga mendorong siswa untuk dapat menerapkannya dalam kehidupan mereka.

Dari pengertian di atas dapat ditarik kesimpulan bahwa Contextual Teaching and Learning (pembelajaran kontekstual) adalah konsep pembelajaran yang membantu pendidik mengaitkan setiap materi yang dipelajari oleh peserta didik dengan kehidupan sehari-hari atau bidangbidang tertentu, sehingga peserta didik dapat merasakan makna dari setiap materi pelajaran yang diterimanya dan mengimplementasikannya dalam berbagai aspek kehidupan. Peserta didik 
memperoleh pengetahuan dan keterampilan dari konteks yang terbatas sedikit demi sedikit, dan dari proses mengonstruksi sendiri, sehingga belajar akan bermakna.

Pendekatan kontekstual mendasarkan diri pada kecenderungan pemikiran tentang belajar sebagai berikut :

a. Proses belajar

1. Belajar tidak hanya sekedar menghafal. Peserta didik harus mengkontruksi pengetahuan di benak mereka.

2. Peserta didik belajar dari mengalami lalu mencatat sendiri pola-pola bermakna dari pengetahuan baru, dan bukan diberi begitu saja oleh pendidik.

3. Para ahli sepakat bahwa pengetahuan yang dimiliki seseorang itu terorganisasi dan mencerminkan pemahaman yang mendalam tentang sesuatu persoalan.

4. Pengetahuan tidak dapat dipisah-pisahkan menjadi faktafakta atau proposisi yang terpisah, tetapi mencerminkan keterampilan yang dapat diterapkan.

5. Manusia mempunyai tingkatan yang berbeda dalam menyikapi situasi baru.

6. Peserta didik perlu dibiasakan memecahkan masalah, menemukan sesuatu yang berguna bagi dirinya, dan bergelut dengan ide-ide.

7. Proses belajar dapat mengubah struktur otak. Perubahan struktur otak itu berjalan terus seiring dengan perkembangan organisasi pengetahuan dan keterampilan seseorang.

b. Transfer pengetahuan peserta belajar dari mengalami sendiri, bukan dari:

1. Pemberian orang lain

2. Keterampilan dan pengetahuan itu diperluas dari konteks yang terbatas (sedikit demi sedikit)

3. Penting bagi peserta didik tahu untuk apa dia belajar dan bagaimana ia menggunakan pengetahuan dan keterampilan itu

c. Lingkungan belajar

1. Belajar efektif itu dimulai dari lingkungan belajar yang berpusat pada peserta didik.

2. Pengajaran harus berpusat pada bagaimana cara peserta didik menggunakan pengetahuan baru mereka. Strategi belajar lebih dipentingkan dibandingkan hasilnya.

3. Umpan balik amat penting bagi peserta didik, yang berasal dari proses penilaian yang benar.

4. Menumbuhkan komunitas belajar dalam bentuk kerja kelompok itu penting.

Menurut Almasdi (2006: 57) Secara garis besar langkah-langkah penerapan Contextual Teaching and Learning dalam kelas sebagai berikut:

1. Kembangkan pemikiran bahwa anak akan belajar lebih bermakna dengan cara bekerja sendiri, menemukan sendiri dan 
mengkontruksi sendiri pengetahuan dan keterampilan barunya.

2. Laksanakan sejauh mungkin kegiatan inquiri untuk semua topik.

3. Kembangkan sifat ingin tahu siswa dengan bertanya.

4. Ciptakan masyaraka belajar (belajar dalam kelompok).

5. Hadirkan model sebagai contoh pembelajaran.

6. Lakukan refleksi di akhir pertemuan.

7. Lakukan penilaian yang sebenarnya dengan berbagai cara.

\section{Ciri-ciri Pembelajaran Contextual} Teaching and Learning
a) Melakukan hubungan yang bermakna
b) Melakukan kegiatan yang signifikan
c) Belajar yang diatur sendiri
d) Saling bekerja sama
e) Berpikir kritis dan kreatif
f) Mengasuh/ memelihara pribadi peserta didik
g) Mencapai standar yang tinggi
h) Menggunakan penilaian yang autentik

Selain itu Contextual Teaching and Learning memiliki cirri yang lain, sebagai berikut:

1. Berbasis masalah: pembelajaran kontekstual dimulai dengan pemberian stimulus atau masalah nyata (real problem). Dalam hal ini siswa menggunakan kemampuan berpikir secara kritis dengan pendekatan yang sistemik untuk menemukan dan memecahkan masalah atau isu tersebut.

2. Penggunaan multi konteks: Teori kognisi menyatakan bahwa pengetahuan itu tidak dapat dipisahkan dari perkembangan konteks, baik fisik maupun social. Bagaimana dan dimana seseorang kan memperoleh dan mengkreasi suatu pengetahuan merupakan hal yang penting. Pembelajaran berbasis kontekstual akan menjadi kaya pengalaman, apabila siswa mempelajari keterampilan dalam berbagai konteks.

3. Mengembangkan keberagaman siswa: pada umumnya keberadaan siswa dalam kelas itu beragam dalam hal nilai, sosial, maupun perspektifnya. Perbedaan atau keberagaman ini bisa dijadikan sebagai motivasi belajar dan dapat pula menyempurnakan pengalaman yang berbasis kontekstual. perbedaan siswa di dalam kelas bisa dijadikan sebagai motivasi belajar serta dapat menyempurnakan pengalaman dalam pembelajaran. Kerjasama tim dan belajar secara kelompok memunculkan sikap respek dari siswa yang berbeda baik dari sisi latar belakang maupun interaksi antarpersonal dianatara mereka.

4. Dorongan belajar mandiri: tujuan jangka panjang pendidikan adalah agar siswa mampu belajar sepanjang hayat 
dan pembelajar sepanjang hayat harus mampu mengidentifikasi, menganalisis, dan menggunakan informasi tanpa harus melalui bantuan atau bimbingan orang lain. Pengalaman belajar dalam Contextual Teaching and Learning harus dapat membangun mental mereka untuk berani melakukan trial and error, disiplin waktu, melakukan refleksi, dan membantu mereka untuk dapat mengubah system belajar dari yang terikat menuju belajar mandiri.

5. Pembentukan kelompok belajar: Keberhasilan siswa dalam pembelajaran dipengaruhi oleh kegiatan saling memberi dan menerima pengetahuan dan kepercayaan diantara mereka. Kelompok belajar atau masyarakat belajar baik yang dibentuk di tempat kerja maupun di sekolah merupakan suatu upaya untuk mewujudkan saling tukar informasi dan pengalaman, fokus terhadap tujuan, dan memungkinkan adanya proses saling belajar dan mengajar. Apabila masyarakat belajar itu dibentuk di sekolah, maka posisi guru adalah sebagai pembimbing, fasilitator, dan pengarah.

6. Penggunaan penilaian otentik: CTL dimaksudkan untuk membangun pengetahuan dan keterampilan yang bermakna melalui pelibatan siswa ke dunia nyata atau konteks yang alamiah. Penilaian sebagai bagian integral dari sistem pembelajaran juga harus menyelaraskan diri dengan tujuan dan metode pembelajaran. Authentic Assesment sebagai suatu model penilaian menekankan bahwa kegiatan penilaian itu dipadukan ke dalam proses belajar mengajar. Model ini memberikan kesempatan dan arahan kepada siswa untuk melakukan perbaikan. Selain itu, Authentic Assesment atau penilaian otentik ini juga dapat digunakan untuk mengetahui kemajuan siswa serta memberikan informasi perihal praktik mengajar.

\section{Prinsip-Prinsip Pembelajaran Contextual Teaching And Learning}

a. Konstruktivisme

Dalam pandangan konstruktivisme, strategi pembelajaran lebih ditekankan dari pada hasil belajar, di mana pendidik diarahkan untuk fokus pada penyiapan strategi, teknik dan metode pengajaran. Sehingga pendidik memposisikan diri sebagai fasilitator pengajaran dan siswa membangun sendiri pengetahuan mereka lewat keterlibatan aktif proses belajar mengajar.
b. Inquiri.
Dalam pandangan inquiri, pengetahuan dan keterampilan yang diperoleh siswa bukan dari hasil mengingat seperangkat fakta-fakta, 
tetapi hasil dari menemukan sendiri. Pendidik harus mempersiapkan rancangan aktivitas pembelajaran yang berorientasi pada menemukan makna dari materi pelajaranyang diajarkan. Siklus inquiri terdiri dari :

1. Observasi atau pengamatan langsung

2. Bertanya

3. Mengajukan dugaan

4. Pengumpulan data

Penyimpulan Langkah-langkah kegiatan inkuiri adalah sebagai berikkut: Merumuskan masalah, Mengamati atau melakukan observas, Menganalisis atau menyajikan hasil dalam tulisan, gambar, laporan, bagan, tabel, dan karya lainnya. Dan Mengkomunikasikan atau menyajikan hasil karya pada pembaca, teman sekelas, guru atau audient yang lain.

\section{c. Questioning (bertanya)}

Kegiatan questioning atau bertanya merupakan kegiatan yang tedapat di seluruh aktivitas belajar. Bahkan bertanya bagi peserta didik menjadi salah satu indikator kegiatan belajarmengajar yang produktif. Kegiatan ini sangat penting karena pendidik akan mengatahui tingkat pengetahuan peserta didik, peserta didik akan mengkonfirmasikan apa yang sudah atau belum diketahui dan pendidik akan mengarahkan perhatian secara khusus pada aspek materi pelajaran yang belum diketahui oleh peserta didik.

Dalam kegiatan yang produktif, kegiatan questioning atau bertanya berguna untuk: :
1. Menggali informasi, baik administrasi maupun akademis

2. Mengecek pemahaman peserta didik

3. Membangkitkan respon kepada peserta didik

4. Mengetahui sejauhmana keinginan peserta didik

5. Mengetahui hal-hal yangsudah diketahui peserta didik

6. Memfokuskan perhatian peserta didik pada sesuatu yang dikehendaki pendidik

7. Membangkitkan lebih banyak lagi pertanyaan dari peserta didik

8. Menyegarkan kembali pengetahuan peserta didik

d. Learning Community (masyarakat belajar)

Konsep ini diarahkan agar pembelajaran yang ada merupakan sebuah proses kerjasama antara individu peserta didik. Pengetahuan yang mereka dapatkan adalah hasil kerjasama tim atau kelompok yang dibentuk oleh pendidik. Melalui interaksi, peserta didik diharapkan dapat mengkomunikasikan pengetahuannya kepada sesama anggota kelompok, sekaligus bersama-sama memecahkan masalah yang ada. Pendidik pada konsep ini berada pada posisi memberi dan melahirkan masalah utama untuk dikaji selanjutnya peserta didiklah yang kemudian melanjutkan kajian berdasarkan instruksi dari pendidik. Learning community atau masyarakat belajar juga mengajarkan kepada peserta didik untuk salaing mengenal perbedaan yang ada baik latar belakang 
sosial sesama peserta didik maupun tingkat pemahaman peserta didik yang satu dengan lainnya.

\section{e. Modelling (pemodelan)}

Modelling atau Pemodelan adalah metode penyajian materi berdasarkan model atau keterampilan tertentu. Metode ini lebih banyak digunakan untuk hal-hal praktis dan membutuhkan contoh yang dilihat secara langsung oleh peserta didik. Dalam pembelajaran kontekstual, pendidik bukan satusatunya model, pendidik bisa saja melibatkan peserta didik untuk memodelkan sesuatu berdasarkan pengalaman yang diketahuinya atau mendatangkan ahli dari luar seperti mendatangkan seseorang yang ahli dibidang astronomi untuk mempelajari tata cara penggunaan teropong bintang.

Banyak pendekatan yang kita kenal dan digunakan dalam proses pembelajaran dan tiap-tiap pendekatan memiliki karakteristik sendiri. Karakteristik ini berhubungan dengan apa yang menjadi fokus dan mendapat tekanan dalam pembelajaran.

Menurut Udin Saefudin Sa'ud (2008: 32) bahwa, pendekatan pembelajaran kontekstual yaitu pendekatan pembelajaran yang berfokus pada siswa, kemampuan berfikir, aktivitas, pengalaman siswa, berfokus pada guru, berfokus pada masalah (personal, lingkungan, social), berfokus pada teknologi seperti system intruksional, media dan sumber belajar.

Berkenan dengan aspek kehidupan dan lingkungan, maka pendekatan pembelajaran ada keterlibatan pada siswa, makna aktivitas, pengalaman dan kemandirian, serta konteks kehidupan dan lingkungan.

Setiap anak memiliki kecenderungan untuk belajar hal-hal yang aneh, baru dan penuh tantangan. Oleh karena itu, belajar bagi mereka mencoba memecahkan persoalan yang menantang. Guru membantu agar setiap siswa mampu mengaitkan antara pengalaman baru dengan sebelumnya, memfasilitasi atau mempermudah agar siswa mampu melakukan proses asimilasi.

Dengan demikian, pendekatan pembelajaran Contekxtual Teaching and Learning menekankan pada aktivitas siswa secara penuh, baik fisik maupun mental. Contextual Teaching and Learning memandang bahwa belajar bukanlah kegiatan menghafal, mengingat fakta-fakta, mendemonstrasikan latihan secara berulang-ulang semata akan tetapi proses berpengalaman dalam kehidupan nyata. Dalam pembelajaran Contextual Teaching and Learning, belajar di alam terbuka merupakan tempat untuk memperoleh informasi sehingga menguji data hasil temuannya itu untuk kemudian dikaji di kelas.

Elaine B. Jhonson (Rusman, 2010) menyimpulkan bahwa pengaruh Contextual Teaching and Learning dapat meningkatkan prestasi belajar siswa karena peserta didik semakin bersemangat belajar ataupun mempunyai kepercayaan diri untuk mengetahui sesuatu yang belum diketahui sehingga membuat peserta didik tidak tertekan dalam proses 
belajar mengajar. Hal ini mempengaruhi secara siknifikan prestasi belajar siswa disekolah dan bisa diaplikasikan dalam kehidupan sehari-hari.

\section{B. KONSEP CTL DALAM PEMBELAJARAN BAHASA} ARAB

Di Indonesia, bahasa Arab dimasukkan ke dalam rumpun bahasa asing. Karena itu sebagaimana layaknya bahasa asing, pembelajaran bahasa Arab kepada peserta didik Indonesia dapat berlangsung secara efektif apabila dilakukan dengan menerapkan strategi dan metode tertentu. Karena pada dasarnya, teori-teori mengenai metode pembelajaran bahasa Arab sama dengan teori-teori pembelajaran bahasa pada umumnya.

Salah satu model pendekatan dalam pembelajaran bahasa Arab yang diharapkan mampu menjadi alternatif dalam pembelajaran bahasa Arab kepada siswa Indonesia adalah metode Contextual Teaching and Learning (CTL).

Pada dasarnya, sebagaimana dijelaskan sebelumnya bahwa metode Contextual Teaching and Learning (pembelajaran kontekstual) adalah suatu pendekatan pembelajaran yang menekankan kepada proses keterlibatan siswa secara penuh sehingga siswa dapat menemukan materi yang dipelajari dan menghubungkannya dengan situasi kehidupan sehari-hari atau bidang-bidang tertentu, sehingga peserta didik dapat merasakan makna dari setiap materi pelajaran yang diterimanya dan mengimplementasikannya dalam berbagai aspek kehidupan.

Dalam pembelajaran bahasa asing, terutama bahasa Arab, pelibatan siswa secara penuh dalam proses pembelajaran adalah hal yang sangat penting karena dalam mempelajari bahasa, interaksi timbal balik antara pengarah dan peserta didik harus dilakukan. Jika seorang pengajar bahasa Arab hanya berfokus pada penyampaian materi atau melibatkan siswa tidak secara penuh, misalnya dengan menyuruh mereka menghafalkan sejumlah mufradat dan kaidah tatabahasa (nahwu) maka bisa ditebak hasil yang dicapai dalam pembelajarannya juga tidak maksimal.

Seperti diketahui, para ahli metodologi pengajaran bahasa Arab kepada non-Arab membagi kemahiran berbahasa Arab kepada empat macam kemahiran, yaitu: 1) Maharat al-Istima' (kemahiran mendengar) 2. Maharat alQira'ah (kemahiran membaca), 3. Maharat al-Hiwar (kemahiran bercakap) dan 4. Maharat al-Kitabah (kemahiran menulis). Semua indikator kemahiran berbahasa Arab di atas dapat dicapai dengan menggunakan pendekatan Contextual Teaching and Learning (pembelajaran kontekstual).

Sebagai contoh, Maharat al-Istima' atau kemahiran mendengar, biasanya diterapkan pada tahap awal pembelajaran bahasa Arab. Mempelajari kemahiran ini sangat penting karena akan memudahkan seseorang untuk mempelajari jenis kemahiran berikutnya dan memungkinkan terjadinya komunikasi langsung antara pembicara 
dan pendengar (Abdullah Abd. alTawwab, 1986:39)

Untuk dapat terlibat langsung dalam suatu komunikasi maka konsekuensinya pengajar bahasa Arab harus melatih dan membiasakan para siswanya Maharat al-Istima' ini. Karena itu, seyogyanya pengajar terlebih dahulu aktif berbahasa Arab di dalam kelas agar siswanya membiasakan diri mendengar kalimatkalimat dalam bahasa Arab.

Adapun Maharah al-Hiwar atau kemahiran bercakap adalah kemampuan peserta didik untuk menyatakan dan mengutarakan konsep pikirannya kepada orang lain secara lisan (verbal). Kemahiran ini penting diajarkan karena merupakan langkah awal menuju kemahiran berikutnya, yakni kemahiran membaca dan kemahiran menulis. Selain itu, kemahiran ini memungkinkan terjadinya komunikasi dua arah atau timbal-balik antara pihak pembicara dan pendengar.

Berkaitan dengan kemahiran berbicara, pengajar bahasa Arab harus mampu menguasai teknik dan metode penyajian kemahiran berbicara ini dengan baik, misalnya dengan metode al-hiwar atau menggunakan alat bantu berupa gambar-gambar sehingga peserta didik dapat berkomunikasi dengan yang lainnya melalui bantuan gambar tersebut.

Sedang pada Maharat al-Qira'ah atau kemahiran membaca, yaitu kemampuan menghubungkan antara bahasa ucapan dengan simbol yang berbentuk tulisan, dan melalui simbol tersebut ia dapat mengutarakan pikiran dan ide-idenya (Muhammad Abdul Kadir Ahmad, 1979:108).

Pembaca yang mahir bersifat otonom dan bisa melakukan kegiatannya di luar kelas. Peserta didik juga tetap dapat berhubungan dengan bahasa sasaran/Arab melalui majalah, buku atau surat kabar yang berbahasa Arab. Fakta ini jelas menunjukkan bahwa pengajaran membaca adalah dalam rangka mengembangkan kemahiran membaca. Dengan demikian adalah merupakan tugas pengajar bahasa Arab untuk meyakinkan bahwa pembelajaran membaca menjadi pengalaman menyenangkan bagi peserta didiknya.

Untuk menjadikan peserta didik senang terhadap teks bacaan, maka pengajar bahasa Arab hendaknya menyiapkan buku-buku bacaan berbahasa Arab dengan beragam topik dan tingkat kesulitan yang berbeda, sehingga peserta didik dapat melatih dirinya untuk membaca teks-teks tersebut di luar waktu belajar.

Terakhir Maharat al-Kitabah atau kemahiran menulis yaitu kemampuan seseorang untuk mengungkapkan konsepsi pikirannya melalui susunan kata-kata berupa simbol-simbol tulisan yang teratur dengan menggunakan kalimat-kalimat yang tepat. Menurut Mahmud Kamil al-Naqah (1978:97), seorang pakar bahasa Arab, kemahiran ini merupakan sarana komunikasi tertulis antara individu dengan individu lainnya. dengan kemahiran ini, manusia akan mengenal gagasan dan ide orang lain, baik yang masih hidup di masa lalu 
ataupun yang masih hidup sampai sekarang.

Menulis merupakan jenis kemahiran yang paling jarang digunakan diantara empat jenis kemahiran lainnya di atas. Hanya sedikit lulusan lembaga atau fakultas pendidikan yang menulis karyanya dalam bahasa Arab, termasuk peserta didik yang belajar di program studi pendidikan bahasa Arab.

Berbicara mengenai kebutuhan dan upaya mempersiapkan peserta didik ke dalam dunia nyata, menulis merupakan kemahiran tersulit untuk diadaptasikan di antara empat jenis kemahiran lainnya di atas, sebab peserta didik diharuskan untuk mengemukakan gagasannya dalam bentuk tulisan dan bahasa yang benar.

Berdasarkan penjelasan sebagaimana dikemukakan di atas, model pendekatan Contextual Teaching and Learning (CTL) adalah alternatif penting dalam pembelajaran bahasa Arab, khususnya kepada siswa Indonesia.

\section{PENUTUP}

Sebagai kesimpulan dari apa yang disampaikan sebelumnya, maka dapat disampaikan beberapa hal berikut:

1. Proses belajar peserta didik sangat dipengaruhi oleh performance dan metode yang digunakan oleh pendidik dalam menyajikan suatu materi pelajaran.

2. Seyogyanya seorang pengajar memiliki daya kreatifitas dalam mengajar dengan menggunakan segala macam metode dan pendekatan yang selaras dengan materi pelajaran yang diajarkan.

3. Contextual Teaching and Learning (CTL) adalah suatu pendekatan pembelajaran yang menekankan kepada proses keterlibatan siswa secara penuh untuk dapat menemukan materi yang dipelajari dan menghubungkannya dengan situasi kehidupan nyata.

4. Contextual Teaching and Learning dapat meningkatkan prestasi belajar siswa karena peserta didik semakin bersemangat belajar ataupun mempunyai kepercayaan diri untuk mengetahui sesuatu yang belum diketahui sehingga membuat peserta didik tidak tertekan dalam proses belajar mengajar.

5. Indikator-indikator kemahiran berbahasa Arab; al-istima', alqira'ah, al-hiwar dan al-kitabah, dapat dicapai dengan menggunakan pendekatan Contextual Teaching and Learning (pembelajaran kontekstual).

\section{DAFTAR PUSTAKA}

Ainin, Moh. 2013. Metodologi Penelitian Bahasa Arab. Malang: BS Press.

Ahmad Sayadi dan Abdul Majid. 2006. Desain Pembelajaran. Jakarta: Renika Cipta.

Almasdi. 2005. Pembelajaran Dalam Implementasi Kurikulum Berbasis Kompetensi. Edisi pertama, cet ke-1. Jakarta : Persada Media 
Arsyad, Azhar. 2003. Bahasa Arab dan Metode Pengajarannya, Cet.I; Yogyakarta: Pustaka Pelajar.

2002 Dasar-dasar Penguasaan Bahasa Arab, Cet.II; Yogyakarta: Pustaka Pelajar.

2002. Manajemen Pendidikan Bahasa Arab, Cet.II; Yogyakarta: Pustaka Pelajar.

Badry, Kamal Ibrahim. 1997. al-Thuruq al- 'Ammah fi Tadris al-Lughah al-Arabiyyah, Jakarta: Penerbit LIPIA.

Dahlan, Juwairiyah. 1992. Metode Belajar Mengajar bahasa Arab, Cet.I; Surabaya: Usaha Nasional.

Din Yati dan Mudjiono. 2006. Strategi Pembelajaran Inovatif Kontemporer: Suatu Tinjauan Konseptual Operasional, Cet I, Jakarta: PT. Bumi Aksara,

al-Naqah, Mahmud Kamil. 1978. Asasiyat Ta'lim al-Lughah al'Arabiyyah fi Ghayri al-'Arab, Sudan: Ma'had Khartoum.

Sanjaya, Wina. 2007. Strategi Pembelajaran Berorientasi Standar Proses Pendidikan. Jakarta: Kencana

Saefudin, Udin. 2008. Inovasi Pendidikan, cet. 1. Bandung: Alfabeta

Sobroto, Suryo. 2009. Prooses Belajar Mengajar DI Sekolah. Jakarta: Rnika Cipta

al-Tawwab, Abdullah. 1986. I'dad Mu'allim al-Lughah al-
'Arabiyyah Li Ghayri alNatiqina Biha, Jakarta: Ma'had al-'Ulum al-Islamiyah wa al'Arabiyyah.

Wena, Made. 2009. Strategi Pembelajaran Inovatif Kontemporer: Suatu Tinjauan Konseptual Operasional, Cet I. Jakarta: PT. Bumi Aksara. 


\title{
INOVASI PEMBELAJARAN BAHASA ARAB
}

\author{
Andi Fajriwati Tadjuddin \\ Dosen Program Studi Pendidikan Bahasa Arab Fakultas Agama Islam \\ Universitas Muhammadiyah Makassar
}

\begin{abstract}
Every people basically has the ability to master every language, even in different levels and drives. While the differences are: the teaching objectives to be achieved, basic skill, self motivation, and interest and persistence. Therefore, to achieve Arabic language ability easily, it needs some innovation in Arabic language teaching and learning process. The innovation in the teaching Arabic language process is by using technology that is growing rapidly this present. The utilization of technology in foreign language learning especially Arabic language will change the academic conditions which be held so far. With this technology, the conditions that are closed and has become such a custom which passed down from generation to generation or hereditary will be eliminated or even disappear and it can be replaced by conditions that are transparent, open, and the process of continuous learning evaluation. Some examples the use of technology in the teaching Arabic language that we can see this present is through the internet media, such as how to learn Arabic grammar, and how to improve reading and understanding, listening, speaking, and writing skills.
\end{abstract}

\section{Keywords: Inovation, learning, arabic language}

\begin{abstract}
Abstrak
Setiap anak manusia pada dasarnya mempunyai kemampuan untuk menguasai setiap bahasa, walaupun dalam kadar dan dorongan yang berbeda. Adapun diantara perbedaanperbedaan tersebut adalah tujuan-tujuan pengajaran yang ingin dicapai, kemampuan dasar yang dimiliki, motivasi yang ada di dalam diri, minat serta ketekunannya. Oleh karena itu, untuk mencapai kemampuan bahasa Arab dengan mudah, dibutuhkan inovasi dalam proses pengajaran bahasa Arab. Adapun inovasi dalam pengajaran bhaasa Arab dewasa ini yaitu pemanfaatan teknologi yang sedang berkembang pesat saat ini. Pemanfaatan teknologi dalam pembelajaran bahasa asing, khususnya bahasa Arab tanpa disadari akan mengubah kondisi akademik yang berjalan selama ini. Dengan teknologi ini kondisi-kondisi yang sifatnya tertutup dan telah menjadi tradisi yang diwariskan secara turun temurun menjadi tersingkirkan atau bahkan lenyap dan digantingan oleh kondisi-kondisi yang bersifat transparan, terbuka, serta adanya proses evaluasi pembelajaran yang berkelanjutan. Adapun contoh pemanfaatan teknologi dalam pengajaran bahasa Arab yang bisa kita lihat saat ini yaitu melalui media internet, diantaranya bagaimana cara belajar tata bahasa Arab, dan bagaimana cara peningkatan kemampuan membaca dan memahami, mendengarkan, berbicara, serta menulis.
\end{abstract}

Kata Kunci: inovasi, pembelajaran, bahasa Arab 


\section{PENDAHULUAN}

elama ini muncul anggapan bahwa - bahasa Arab adalah bahasa yang rumit dan sulit dipelajari, bahkan pelajaran bahasa Arab disekolah-sekolah menjadi momok yang menakutkan bagi para siswa. Anggapan tersebut yang akhirnya menjadi penghambat dalam proses pembelajaran bahasa Arab di sekolah. Selama ini para siswa masih mengalami kesulitan, baik dalam membuat tulisan atau karangan berbahasa Arab, maupun berkomunikasi secara lisan menggunakan bahasa Arab. Dari sini dapat disimpulkan bahwa pembelajaran bahasa Arab selama ini belum berhasil.

Beberapa faktor yang menyebabkan ketidakberhasilan dalam pembelajaran bahasa Arab diantaranya adalah faktor dari dalam diri siswa yang menganggap bahasa Arab adalah pelajaran yang sulit, dan kurangnya kepercayaan diri mereka dalam berkomunikasi dengan menggunakan bahasa Arab. Selain itu kurangnya media dan sarana yang mendukung siswa untuk belajar bahasa Arab termasuk kurangnya kompetensi guru bahasa Arab.

Setiap anak manusia pada dasarnya mempunyai kemampuan untuk menguasai setiap bahasa, walaupun dalam kadar dan dorongan yang berbeda. Adapun diantara perbedaan-perbedaan tersebut adalah tujuan-tujuan pengajaran yang ingin dicapai, kemampuan dasar yang dimiliki, motivasi yang ada di dalam diri, minat serta ketekunannya.

Tujuan Pengajaran Belajar bahasa ibu (bahasa bawaan -edt) merupakan tujuan yang hidup, yaitu sebagai alat komunikasi untuk mencapai sesuatu yang diinginkan dalam hidupnya, oleh karena itu motivasi untuk belajarnya sangat tinggi. Sementara itu belajar bahasa asing, seperti bahasa Arab (bagi non Arab), pada umumnya mempunyai tujuan sebagai alat komunikasi dan ilmu pengetahuan (kebudayaan). Namun bahasa asing tidak dijadikan sebagai bahasa hidup seharihari, oleh karena itu motivasi belajar bahasa Arab lebih rendah daripada bahasa ibu. Padahal besar kecilnya motivasi belajar bahasa Arab mempengaruhi hasil yang akan dicapai.

Kemampuan dasar yang dimiliki ketika anak kecil belajar bahasa ibu, otaknya masih bersih dan belum mendapat pengaruh bahasa-bahasa lain, oleh karena itu ia cenderung dapat berhasil dengan cepat. Sementara ketika mempelajari bahasa Arab, ia telah lebih dahulu menguasai bahasa ibunya, baik lisan, tulis, maupun bahasa berpikirnya. Oleh karena itu mempelajari bahasa Arab tentu lebih sulit dan berat, karena ia harus menyesuaikan sistem bahasa ibu ke dalam sistem bahasa Arab, baik sistem bunyi, struktur kata, struktur kalimat maupun sistem bahasa berpikirnya.

Adapun rumusan masalah dari tulisan ini yaitu :

1. Bagaimana prinsip-prinsip pembelajaran bahasa arab?

2. Bagaimana metode pengajaran Bahasa Arab?

3. Bagaimana pendekatan pembelajaran Bahasa Arab?

4. Bagaimana inovasi pembelajaran Bahasa Arab?

5. Bagaimana pembelajaran Bahasa Arab Berbasis IT? 


\section{PEMBAHASAN}

\section{Prinsip-prinsip dalam Pembelajaran Bahasa Arab (asing)}

Ada lima prinsip dasar dalam pengajaran bahasa Arab asing, yaitu prinsip prioritas dalam proses penyajian, prinsip koreksitas dan umpan balik, prinsip bertahap, prinsip penghayatan, serta korelasi dan isi;

\section{Prinsip prioritas}

Dalam pembelajaran Bahasa Arab, ada prinsip-prinsip prioritas dalam penyampaian materi pengajaran, yaitu; Pertama, mengajarkan, mendengarkan, dan bercakap sebelum menulis. Kedua, mengakarkan kalimat sebelum mengajarkan kata. Ketiga, menggunakan kata-kata yang lebih akrab dengan kehidupan sehari-hari sebelum mengajarkan bahasa sesuai dengan penutur Bahasa Arab.

a. Mendengar dan berbicara terlebih dahulu daripada menulis. Prinsip ini berangkat dari asumsi bahwa pengajaran bahasa yang baik adalah pengajaran yang sesuai dengan perkembangan bahasa yang alami pada manusia2, yaitu setiap anak akan mengawali perkembangan bahasanya dari mendengar dan memperhatikan kemudian menirukan. Hal itu menunjukkan bahwa kemampuan mendengar/menyimak harus lebih dulu dibina, kemudian kemampuan menirukan ucapan, lalu aspek lainnya seperti membaca dan menulis. Ada beberapa teknik melatih pendengaran/telinga,yaitu:

b. Guru bahasa asing (Arab) hendaknya mengucapkan kata-kata yang beragam, baik dalam bentuk huruf maupun dalam kata. Sementara peserta didik menirukannya di dalam hati secara kolektif.

c. Guru bahasa asing kemudian melanjutkan materinya tentang bunyi huruf yang hampir sama sifatnya.

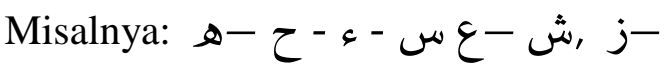
ذ dan seterusnya.

d. Selanjutnya materi diteruskan dengan tata bunyi yang tidak terdapat di dalam bahasa ibu (dalam hal ini bahasa indonesia, -edt) peserta didik, seperti: $\dot{\tau}, \dot{j}, \dot{\text { D }}$ dan seterusnya.

Adapun dalam pengajaran pengucapan dan peniruan dapat menempuh langkah-langkah berikut :

1) Peserta didik dilatih untuk melafalkan huruf-huruf tunggal yang paling mudah dan tidak asing, kemudian dilatih dengan huruf-huruf dengan tanda panjang dan kemudian dilatih dengan lebih cepat dan seterusnya dilatih dengan melafalkan kata-kata dan kalimat dengan cepat. Misalnya :

dan seterusnya.

2) Mendorong peserta didik ketika proses pengajaran menyimak dan melafalkan huruf atau kata-kata untuk menirukan intonasi, cara berhenti, maupun panjang pendeknya.

3) Mengajarkan kalimat sebelum mengajarkan bahasa

Dalam mengajarkan struktur kalimat, sebaiknya mendahulukan mengajarkan struktur kalimat/nahwu, baru kemudian masalah struktur kata/sharaf. Dalam mengajarkan kalimat/jumlah sebaiknya seorang guru memberikan hafalan 
teks/bacaan yang mengandung kalimat sederhana dan susunannya benar.

Oleh karena itu, sebaiknya seorang guru bahasa Arab dapat memilih kalimat yang isinya mudah dimengerti oleh peserta didik dan mengandung kalimat inti saja, bukan kalimat yang panjang (jika kalimatnya panjang hendaknya di penggal - penggal). Contoh:

$$
\text { اشتريت سيارة صغيرة بيضياء }
$$

$$
\text { مستعملة مصنوعة في اليابان Kemudian }
$$

dipenggal - penggal menjadi :

$$
\text { اشتريت سيارة اشتريت سيارة صغيرة Dan }
$$

seterusnya.

\section{Prinsip korektisitas}

Prinsip ini diterapkan ketika sedang mengajarkan materi الأصيوات (fonetik),

$$
\text { التمانى التراكب (sintaksis), dan dan }
$$

(semiotic). Maksud dari prinsip ini adalah seorang guru bahasa Arab hendaknya jangan hanya bisa menyalahkan pada peserta didik, tetapi ia juga harus mampu melakukan pembetulan dan membiasakan pada peserta didik untuk kritis pada halhal berikut: Pertama, korektisitas dalam pengajaran (fonetik). Kedua, korektisitas dalam pengajaran (sintaksis). Ketiga, korektisitas dalam pengajaran (semiotic).

a. Korektisitas dalam pengajaran fonetik Pengajaran aspek keterampilan ini melalui latihan pendengaran dan ucapan. Jika peserta didik masih sering melafalkan bahasa ibu, maka guru harus menekankan latihan melafalkan dan menyimak bunyi huruf Arab yang sebenarnya secara terus-menerus dan fokus pada kesalahan peserta didik.

b. Korektisitas dalam pengajaran sintaksis Perlu diketahui bahwa struktur kalimat dalam bahasa satu dengan yang lainnya pada umumnya terdapat banyak perbedaan. Korektisitas ditekankan pada pengaruh struktur bahasa ibu terhadap Bahasa Arab. Misalnya, dalam bahasa Indonesia kalimat akan selalu diawali dengan kata benda (subyek), tetapi dalam bahasa Arab kalimat bisa diawali dengan kata kerja ( فعل). c.Korektisitas dalam pengajaran semiotik Dalam bahasa Indonesia pada umumnya setiap kata dasar mempunyai satu makna ketika sudah dimasukan dalam satu kalimat. Tetapi, dalam bahasa Arab, hampir semua kata mempunyai arti lebih dari satu, yang lebih dikenal dengan istilah mustarak (satu kata banyak arti) dan mutaradif (berbeda kata sama arti). Oleh karena itu, guru bahasa Arab harus menaruh perhatian yang besar terhadap masalah tersebut. Ia harus mampu memberikan solusi yang tepat dalam mengajarkan makna dari sebuah ungkapan karena kejelasan petunjuk.

\section{Prinsip Berjenjang.}

Jika dilihat dari sifatnya, ada 3 kategori prinsip berjenjang, Yaitu: pertama, pergeseran dari yang konkrit ke yang abstrak, dari yang global ke yang detail, dari yang sudah diketahui ke yang 
belum diketahui. Kedua, ada kesinambungan antara apa yang telah diberikan sebelumnya dengan apa yang akan ia ajarkan selanjutnya. Ketiga, ada peningkatan bobot pengajaran terdahulu dengan yang selanjutnya, baik jumlah jam maupun materinya.

a. Jenjang Pengajaran mufrodat Pengajaran kosa kata hendaknya mempertimbangkan dari aspek penggunaannya bagi peserta didik, yaitu diawali dengan memberikan materi kosa kata yang banyak digunakan dalam keseharian dan berupa kata dasar. Selanjutnya memberikan materi kata sambung. Hal ini dilakukan agar peserta didik dapat menyusun kalimat sempurna sehingga terus bertambah dan berkembang kemampuannya.

b. Jenjang Pengajaran Qowaid (Morfem) Dalam pengajaran Qowaid, baik Qowaid Nahwu maupun Qowaid Sharaf juga harus mempertimbangkan kegunaannya dalam, percakapan/ keseharian. Dalam pengajaran Qawaid Nahwu misalnya, harus diawali dengan materi tentang kalimat sempurna (Jumlah Mufiidah), namun rincian materi penyajian harus dengan cara mengajarkan tentang isim, fi'il, dan huruf.

c. Tahapan pengajaran makna ( دلالة

Dalam mengajarkan makna kalimat atau kata-kata, seorang guru bahasa Arab hendaknya memulainya dengan memilih kata-kata/kalimat yang paling banyak digunakan/ditemui dalam keseharian meraka. Selanjutnya makna kalimat lugas sebelum makna kalimat yang mengandung arti idiomatic. Dilihat dari teknik materi pengajaran bahasa Arab, tahapantahapannya dapat dibedakan sebagai berikut: pertama, pelatihan melalui pendengaran sebelum melalui penglihatan. Kedua, pelatihan lisan/pelafalan sebelum membaca. Ketiga, penugasan kolektif sebelum individu. Langkah-langkah aplikasi ( (الصلابة والمتا ناة

Ada delapan langkah yang diperlukan agar teknik diatas berhasil dan dapat terlaksana, yaitu :

1) Memberikan contoh-contoh sebelum memberikan kaidah gramatika, karena contoh yang baik akan menjelaskan gramatika secara mendalam daripada gramatika saja.

2) Jangan memberikan contoh hanya satu kalimat saja, tetapi harus terdiri dari beberapa contoh dengan perbedaan dan persamaan teks untuk dijadikan analisa perbandingan bagi peserta didik.

3) Mulailah contoh-contoh dengan sesuatu yang ada di dalam ruangan kelas/media yang telah ada dan memungkinkan menggunakannya.

4) Mulailah contoh-contoh tersebut dengan menggunakan kata kerja yang bisa secara langsung dengan menggunakan gerakan anggota tubuh.

5) Ketika mengajarkan kata sifat hendaknya menyebutkan kata-kata yang paling banyak digunakan dan lengkap dengan pasangannya. Misalnya hitam-putih, bundar-persegi.

6) Ketika mengajarkan huruf jar dan maknanya, sebaiknya dipilih huruf jar yang paling banyak digunakan dan 
dimasukkan langsung ke dalam kalimat yang paling sederhana.

Contoh Jumlah ismiyyah: الكتاب في

الصندوق, Contoh jumlah fi'iliyah :

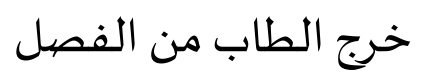

7) Hendaknya tidak memberikan contohcontoh yang membuat peserta didik harus meraba-raba karena tidak sesuai dengan kondisi pikiran mereka.

8) Peserta didik diberikan motivasi yang cukup untuk berekspresi melalui tulisan, lisan bahkan mungkin ekspresi wajah, agar meraka merasa terlibat langsung dengan proses pengajaran yang berlangsung.

\section{Metode Pengajaran Bahasa Arab}

Ibnu khaldun berkata, "Sesungguhnya pengajaran itu merupakan profesi yang membutuhkan pengetahuan, keterampilan, dan kecermatan karena ia sama halnya dengan pelatihan kecakapan yang memerlukan kiat, strategi dan ketelatenan, sehingga menjadi cakap dan professional." Penerapan metode pengajaran tidak akan berjalan dengan efektif dan efisien sebagai media pengantar materi pengajaran bila penerapannya tanpa didasari dengan pengetahuan yang memadai tentang metode itu. Sehingga metode bisa saja akan menjadi penghambat jalannya proses pengajaran, bukan komponen yang menunjang pencapaian tujuan, jika tidak tepat aplikasinya. Oleh karena itu, penting sekali untuk memahami dengan baik dan benar tentang karakteristik suatu metode. Secara sederhana, metode pengajaran bahasa Arab dapat digolongkan menjadi dua macam, yaitu: pertama, metode tradisional/klasikal dan kedua, metode modern.

Metode pengajaran bahasa Arab tradisional adalah metode pengajaran bahasa Arab yang terfokus pada "bahasa sebagai budaya ilmu" sehingga belajar bahasa Arab berarti belajar secara mendalam tentang seluk-beluk ilmu bahasa Arab, baik aspek gramatika/sintaksis (Qowaid nahwu), morfem/morfologi (Qowaid as-sharf) ataupun sastra (adab). Metode yang berkembang dan masyhur digunakan untuk tujuan tersebut adalah Metode qowaid dan tarjamah. Metode tersebut mampu bertahan beberapa abad, bahkan sampai sekarang pesantren-pesantren di Indonesia, khususnya pesantren salafiah masih menerapkan metode tersebut. Hal ini didasarkan pada hal-hal sebagai berikut: Pertama, tujuan pengajaran bahasa arab tampaknya pada aspek budaya/ilmu, terutama nahwu dan ilmu sharaf. Kedua kemampuan ilmu nahwu dianggap sebagai syarat mutlak sebagai alat untuk memahami teks/kata bahasa Arab klasik yang tidak memakai harakat, dan tanda baca lainnya. Ketiga, bidang tersebut merupakan tradisi turun temurun, sehingga kemampuan di bidang itu memberikan "rasa percaya diri (gengsi) tersendiri di kalangan mereka".

Metode pengajaran bahasa Arab modern adalah metode pengajaran yang berorientasi pada tujuan bahasa sebagai alat. Artinya, bahasa Arab dipandang sebagai alat komunikasi dalam kehidupan modern, sehingga inti belajar bahasa Arab adalah kemampuan untuk menggunakan bahasa tersebut secara aktif dan mampu memahami ucapan/ungkapan dalam 
bahasa Arab. Metode yang lazim digunakan dalam pengajarannya adalah metode langsung (tariiqah al mubasysyarah). Munculnya metode ini didasari pada asumsi bahwa bahasa adalah sesuatu yang hidup, oleh karena itu harus dikomunikasikan dan dilatih terus sebagaimana anak kecil belajar bahasa.

1) Metode Qowa'id dan tarjamah (Tariiqatul al Qowaid Wa Tarjamah)

Penerapan metode ini lebih cocok jika tujuan pengajaran bahasa Arab adalah sebagai kebudayaan, yaitu untuk mengetahui nilai sastra yang tinggi dan untuk memiliki kemampuan kognitif yang terlatih dalam menghafal teks-teks serta memahami apa yang terkandung di dalam tulisan-tulisan atau buku-buku teks, terutama buku Arab klasik11. Ciri metode ini adalah :

a. Peserta didik diajarkan membaca secara detail dan mendalam tentang teks-teks atau naskah pemikiran yang ditulis oleh para tokoh dan pakar dalam berbagai bidang ilmu pada masa lalu baik berupa sya'ir, naskah (prosa), kata mutiara (alhikam), maupun kiasan-kiasan (amtsal).

b. Penghayatan yang mendalam dan rinci terhadap bacaan sehingga peserta didik memiliki perasaan koneksitas terhadap nilai sastra yang terkandung di dalam bacaan. (bahasa Arab - bahasa ibu).

c. Menitikberatkan perhatian pada kaidah gramatika (Qowa'id Nahwu/Sharaf) untuk menghafal dan memahami isi bacaan.

d. Memberikan perhatian besar terhadap kata-kata kunci dalam menerjemah, seperti bentuk kata kiasan, sinonim, dan meminta peserta didik menganalisis dengan kaidah gramatikal yang sudah diajarkannya (mampu menerjemah bahasa ibu ke dalam Bahasa Arab).

\section{2) Metode langsung (al Thariiqatu al Mubaasyarah)}

Penekanan pada metode ini adalah pada latihan percakapan terus-menerus antara guru dan peserta didik dengan menggunakan bahasa Arab tanpa sedikitpun menggunakan bahasa ibu, baik dalam menjelaskan makna kosa kata maupun menerjemah, (dalam hal ini dibutuhkan sebuah media). Perlu menjadi bahan revisi disini adalah bahwa dalam metode langsung, bahasa Arab menjadi bahasa pengantar dalam pengajaran dengan menekankan pada aspek penuturan yang benar ( $a l-N u t q u a l-$ Shahiih), oleh karena itu dalam aplikasinya, metode ini memerlukan halhal berikut :

a. Materi pengajaran pada tahap awal berupa latihan oral (syafawiyah)

b. Materi dilanjutkan dengan latihan menuturkan kata-kata sederhana, baik kata benda ( $i s i m$ ) atau kata kerja ( fi'il) yang sering didengar oleh peserta didik.

c. Materi dilanjutkan dengan latihan penuturan kalimat sederhana dengan menggunakan kalimat yang merupakan aktifitas peserta didik sehari-hari.

d. Peserta didik diberikan kesempatan untuk berlatih dengan cara Tanya jawab dengan guru/sesamanya.

e. Materi Qiro'ah harus disertai diskusi dengan bahasa Arab, baik dalam 
menjelaskan makna yang terkandung di dalam bahan bacaan ataupun jabatan setiap kata dalam kalimat.

f. Materi gramatika diajarkan di selasela pengajaran,namun tidak secara mendetail.

g. Materi menulis diajarkan dengan latihan menulis kalimat sederhana yang telah dikenal/diajarkan pada peserta didik.

\section{3) Metode eklektik (tariqah al- intiqaiyyah)}

Pendekatan pembelajaran di atas memerlukan metode pembelajaran yang tepat. Plihan yang tepat adalah metode eklektik, yaitu metode gabungan yang mengambil aspek-aspek positifnya baik dari keterampilan maupun pengetahuan bahasa, sehingga mencapai tujuaan dan hasil pembelajaran yang maksimal. Metode eklektif dimaksud mencakup metode percakapan,membaca, latihan, dan tugas, Adapun rancangan materi ajar dan desainnya adalah sebagai berikut :

a. Materi Ajar Bahasa Arab

1) Jika kita amati suatu materi ajar bahasa terdiri atas (1) topik materi ajar dan (2) desainnya yang menggambarkan kegiatan pembelajarannya.

2) Topik materi ajar bahasa Arab yang efektif adalah topik-topik yang komunikatif dan kontekstual tentang tema keseharian, keagamaan, iptek, dan kebudayaan.

b. Desainya pembelajarannya mencakup
1) Keterampilan Mendengar dan Berbicara (Istima'-Kalam)

2) Teks Percakapan yang komunikatif dan kontekstual

3) Mufradat

4) Tadribat (Pelatihan)

5) Ajril Hiwar kama fil mitsal (Percakapkanlah sbg. contoh)

6) Hawwil kama fil mitsal (Rubahlah sbg. contoh)

7) Baddil kama fil mitsal (gantilah sbg. contoh)

8) Al'ab lughowiyah (permainan bahasa)

9) Wajib (Tugas)

10) Keterampilan Membaca dan Menulis (Qira'ah-Kitabah)

11) Teks bacaan yang komunikatif, pragmatik, dan kontekstual.

12) Mufradat

13) Contoh-contoh teks yang struktural, komunikatif, dan kontekstual.

14) Penjelasan dan kesimpulan (oleh pemelajar atau pengajar)

15) Latihan Membaca

16) Bacalah dengan membunyikan semua baris akhirnya.

17) Terjemahkan teks bacaan ke dalam bahasa Indonesia standar.

18) Sebutkan jenis kata yang diberi garis bawah

19) Jelaskan terjadinya perubahan baris akhir pada kata yang diberi garis bawah.

20) Jelaskan i'rab kata-kata yang diberi garis bawah dan alasannya (setelah pemelajar mempelajari sejumlah materi ajar yang mengantarnya ke arah ini)

21) Wajib (Tugas) 
Pendekatan Pembelajaran Bahasa Arab

Sesuai dengan tujuan di atas, pendekatan pembelajaran yang efektif mencakup empat pendekatan, yaitu pendekatan humanistik, komuni-katif, kontekstual, dan struktural.

1. Pendekatan humanistik melihat bahwa pembelajaran bahasa Arab memerlukan keaktifan pemelajarnya, bukan pengajar. Pemelajarlah yang aktif belajar bahasa dan pengajar berfungsi sebagai motivator, dinamisator, administrator, evaluator, dsb.Pengajar harus memanfaatkan semua potensi yang dimiliki pemelajar.

2. Pendekatan komunikatif melihat bahwa fungsi utama bahasa adalah komunikasi.Hal ini berarti materi ajar bahasa Arab harus materi yang praktis dan pragmatis, yaitu materi ajar terpakai dan dapat dikomunikasikan oleh pemelajar secara lisan maupun tulisan. Materi ajar yang tidak komunikatif akan kurang efektif dan mem-buang waktu saja.

3. Pendekatan kontekstual melihat bahasa sebagai suatu makna yang sesuai dengan kebutuhan pemelajar dan setingnya. Di sini, rancangan materi ajar harus berdasarkan kebutuhan lembaga, kebu-tuhan pemelajar hari ini dan ke depan.

4. Pendekatan struktural melihat bahwa pembelajaran bahasa sebagai hal yang formal. Oleh sebab itu, struktur bahasa (qawaid) harus mendapat perhatian dalam merancang materi ajar. Namun struktur harus fungsional agar komunikatif dan praktis.
Qawaid/ grammar yang tidak praktis dan tidak komunikatif dalam pembelajaran bahasa Arab telah gagal membentuk pemelajar terampil berbahasa, bukan saja bahasa Arab tetapi juga bahasa Inggris.

\section{Pelaksanaan Pembelajaran}

Untuk mencapai hasil belajar bahasa Arab yang efektif dan maksimal, lembaga-lembaga pendidikan harus melakukan dua kegiatan, (1) pembelajaran, learning, dan pemerolehan bahasa, language acquisition. Pembelajaran membentuk keterampilan berbahasa secara formal, sedangkan pemerolehan membentuk pemakaian bahasa secara non formal. Kedua cara ini menuntut pengajar dan petugas untuk mempersiapkan rencana pelaksanaan pembelajaran (RPP) yang bermutu, yaitu pembelajaran yang terukur dan terkontrol serta adanya komitmen dari semua komponen terkait.

$$
\text { Minat dan motivasi }
$$
pemelajar/mahasiswa akan tumbuh jika materi ajar didesai dengan baik dan tenaga pengajarnya profesional. Tenaga pe-ngajar tidak boleh mengajar sebelum ada pembelakalan yang diinginkan oleh komitmen lembaga. Sebab keterampilan mahasiswa dalam berba-hasa dan berpengetahuan bahasa berhubungan dengan keterampilan tenaga pengajarnya. Cara seperti inilah yang dilakukan oleh lembaga-lembaga pengajaran bahasa yang ingin membentuk outcome-nya bermutu dan mempunyai ciri yang tampil beda dari yang lainnya. 


\section{Inovasi Pembelajaran Bahasa Arab}

Kehadiran dan perkembangan teknologi yang sangat pesat telah menyebabkan terjadinya proses perubahan dramatis dalam segala aspek kehidupan, termasuk pendidikan. Kehadiran teknologi tidak memberikan pilihan lain kepada dunia pendidikan selain turut serta dalam memanfaatkannya. Karena pada hakikatnya, teknologi adalah solusi bagi beragam masalah pendidikan saat ini. Kecanggihan, ketepatan serta kecepatan dalam menyampaikan suatu informasi menjadikan teknologi menduduki posisi penting di berbagai bidang termasuk di bidang pendidikan. Pemanfaatan teknologi dalam pembelajaran diharapkan akan dapat meningkatkan kualitas pembelajaran serta memperluas jaringan pendidikan dan pembelajaran karena teknologi telah menjadikan ilmu pengetahuan lebih mudah diakses, dipublikasikan dan disimpan. Selain itu pemanfaatan teknologi diharapkan pula dapat mengurangi biaya pendidikan, serta memberikan sumbangsih terhadap upaya integritas ilmu pengetahuan.

Saat ini, sistem pendidikan yang tidak memanfaatkan teknologi akan menjadi kadaluwarsa dan kehilangan kredibilitasnya. Namun, di sisi lain ada juga pendapat yang menyatakan bahwa situasi ini lebih disebabkan oleh adanya konspirasi yang mengakibatkan terjadinya ketergantungan dunia pendidikan terhadap teknologi ini. Kedua pendapat itu tidak perlu diperdebatkan karena memiliki kesahihan tersendiri dari perspektifnya masing-masing. Justru, yang seharusnya menjadi perhatian adalah bagaimana dampak teknologi terhadap sistem pendidikan, terutama sistem pembelajaran, serta bagaimana strategi pemanfaatan teknologi dalam pembelajaran. Karena toh teknologi sudah berjalan dan sangat tidak mungkin untuk dapat dibendung. Dalam usaha mewujudkan hal tersebut, tentu diperlukan langkah-langkah strategis agar dapat diperoleh hasil yang optimal.

Bagi siapa pun yang sedang melakukan pembelajaran bahasa asing pada saat ini, dengan segala atributnya, teknologi menjadi hal yang tidak dapat dihindarkan lagi. Beragam kemungkinan ditawarkan oleh teknologi untuk meningkatkan kualitas pembelajaran bahasa asing. Di antaranya adalah sebagai sarana peningkatan dan pengembangan kemampuan profesional tenaga pengajar, sebagai sumber belajar dalam pembelajaran, sebagai alat bantu interaksi pembelajaran, dan sebagai wadah pembelajaran.

Perubahan budaya pembelajaran bahasa asing sebagai akibat pemanfaatan teknologi sangat bergantung pada berbagai komponen dalam sistem pendukung pembelajaran. Ada beberapa hal yang menjadikan teknologi kurang mendapatkan tempat dalam budaya pembelajaran bahasa asing di beberapa institusi pendidikan. Faktor yang paling utama disebabkan karena tenaga pengajar sebagai salah satu komponen terpenting yang sangat berperan dalam perubahan tersebut. tidak mempunyai skill yang mencukupi di bidang ini. Oleh karena itu, tenaga pengajar saat ini dituntut untuk memiliki kemampuan kreatif dan inovatif serta wawasan tentang perubahan 
tersebut. Di samping itu, tenaga pengajar juga dituntut untuk memiliki keterampilan teknis penguasaan teknologi agar dapat melakukan perubahan secara operasional, dan bersikap positif terhadap teknologi serta perubahannya.

Di samping tenaga pengajar, pembelajar juga perlu dipersiapkan, begitu juga para administrator pembelajaran, karena tidak ada perubahan yang terjadi secara isolatif dan dalam kondisi vakum. Dengan demikian, perubahan budaya pembelajaran yang diakibatkan oleh pemanfaatan teknologi bukan hanya untuk segelintir orang saja, atau satu dua komponen saja, namun berlaku bagi semua tatanan sistem pembelajaran, bahkan sistem pendidikan di suatu institusi pendidikan secara umum. Konsekuensinya, dampak maupun hasil dari perubahan budaya pembelajaran bahasa asing juga menjadi milik seluruh pihak yang berkontribusi di dalamnya.

Pemanfaatan teknologi dalam pembelajaran bahasa asing tanpa sadar telah mengubah kondisi akademik yang berjalan selama ini. Dengan teknologi ini kondisi-kondisi yang sifatnya tertutup dan telah menjadi tradisi yang diwariskan secara turun temurun menjadi tersingkirkan atau bahkan lenyap dan digantingan oleh kondisi-kondisi yang bersifat transparan, terbuka, serta adanya proses evaluasi pembelajaran yang berkelanjutan.

\section{Pembelajaran Bahasa Arab Berbasis IT}

Dewasa ini, perkembangan teknologi informasi dan multimedia amat pesat. Dunia cyber sudah tidak asing lagi bahkan telah menjadi trend dan bagian yang tak bisa lagi terelakkan dari kehidupan sehari-hari terutama bagi masyarakat modern. Dalam upaya integrasi antara teknologi (internet) dan pendidikan (pembelajaran bahasa), tulisan singkat ini akan memberikan informasi bagaimana pembelajaran bahasa Arab dengan memanfaatkan media internet. Di antaranya bagaimana cara belajar tata bahasa Arab, dan bagaimana cara peningkatan kemampuan membaca dan memahami, mendengarkan, berbicara, serta menulis.

\section{Belajar Tata Bahasa Arab}

Untuk mempelajari tata bahasa Arab, saat ini sudah banyak sekali situs yang secara khusus menampilkan materi pelajaran bahasa Arab online baik dalam bahasa Indonesia, Arab, maupun Inggris.

\section{Meningkatkan \\ Kemampuan \\ Membaca dan Memahami}

Untuk mendukung peningkatan kemampuan membaca dan memahami, internet menyediakan bahan-bahan bacaan yang dapat di-download secara bebas dan gratis selain juga yang ditampilkan secara online.

\section{Meningkatkan}

Kemampuan

\section{Mendengar}

Untuk melatih kemampuan ini beberapa situs yang dapat dikunjungi (untuk mendengarkan beberapa lagu, puisi, pidato, dan juga percakapan berbahasa Arab), (Untuk mendengarkan pembacaan puisi), (untuk mendengarkan lagu), (untuk mendengarkan pidato), dan masih banyak lagi lainnya.

\section{Meningkatkan}

\section{Berbicara}

Untuk menunjang kemampuan berbicara dalam bahasa Arab, internet 
menyajikan beberapa situs yang memuat materi-materi percakapan bahasa Arab secara online, Atau Anda juga dapat mempraktekkan langsung melalui ruang chat dengan MIRC atau Yahoo Massenger. Jika Anda menggunakan mIRC, konsekuensinya Anda harus menggunakan transliterasi latin dalam mengungkapkan bahasa Arab, karena kebanyakan di warnet sekitar kita belum memberikan fasilitas Arabic. Seperti jika Anda menanyakan kabar, Anda dapat mengetikkan kata: Kaifa Haluk? (bahasa formal), Izayyak? (Bahasa nonformal). Jika Anda menggunakan Yahoo Massenger, Anda dapat berhubungan langsung dengan memanfaatkan fasilitas Call selain juga chatting sebagaimana di mIRC.

\section{Meningkatkan Kemampuan Menulis}

Pengasahan kemampuan menulis dengan memanfaatkan teknologi internet dapat dilakukan dengan cara banyak membaca berita dan makalah yang disajikan dalam situs-situs berbahasa Arab kemudian menirukan susunan dan style/gaya bahasa yang dipergunakan dengan melakukan beberapa modifikasi kalimat. Adapun aplikasinya dapat dilakukan melalui fasilitas e-mail. Caranya, buatlah surat Anda dalam bahasa Arab pada Microsoft Word atau sejenisnya dan kirimlah dengan menggunakan Attachment melalui e-mail Anda. Anda dapat mengirimkan ke beberapa penulis Arab terkemuka yang mencantumkan alamat e-mailnya di situssitus Arab, semisal para pemikir, sastrawan, jurnalis, pemuka agama dan sebagainya. Atau teman chating Anda yang berada di sana. Tulislah surat secara rutin, dan jangan pernah putus asa jika surat Anda tidak dibalas.

\section{KESIMPULAN}

1. Sudah seharusnya setiap lembaga pendidikan yang mengajarkan bahasa Arab harus merubah paradigmanya, dari yang tidak efektif, tidak komunikatif, tidak kontekstual kepada yang lebih efektif, komunikatif, dan kontekstual.

2. Materi ajar didesain untuk membentuk keterampilan berbahasa dan pengetahuan praktis/terapan.

3. Tenaga pengajar harus terlatih, tidak boleh mengajar sebelum memenuhi syarat yang diinginkan lembaga. Maka lembaga pengajaran harus melakukan seleksi terhadap tenaga pengajarnya.

\section{DAFTAR PUSTAKA}

Abdurrahman al - Qadir Ahmad. 1979. Thuruqu Ta'alim al - Lughah al 'Arabiyah, Maktabah al - Nahdah, al - Mishriyah, Kairo.

Ahmad al - Sya'alabi. 1961. Tarikh al Tarbiyah al - Islamiyah, Cet. 11, Kairo: tnp.,

Ahmad Syalaby. 1983. Ta'lim al Lughah al 'Arabiyah lighairi al 'Arab, Maktabah al - Nahdhah al Mishriyah, Kairo

Anis Farihah. 1983. Nazhriyaat Hal Lughah, dar al - Kitab al - Ubnany, Beirut, dar al - Kitab al - Ubnany. 
Ibrahim Muhammad 'Atha. $1416 \mathrm{H}$. Thuruqu Tadris al - Lughah al 'Arabiyah Wa al - Tarbiyah al Diniyah, Maktabah al - Nahdhah al - Mishriyah, Kairo.

Jassem Ali Jassem. 1996. Thuruqu Ta'lim al - Lughah al - 'arabiyah Li al Ajanib. Kuala Lumpur : A.S Noorden.

Kamal Ibrahim Badri dan Mahmud Nuruddin. 1406 H. Nadzkarah Asas al - Ta'lim al - Lughah al ajnubiyah, LIPIA, Jakarta.

Muhammad Jawwad Ridla. 2002. Tiga Aliran Utama Teori Pendidikan Islam (perspektif sosiologifilosofis). P.T Tiara Wacana, Yogyakarta.

Munir M.Ag. 2005. Pengajaran Bahasa Arab Sebagai Bahasa Asing. yang terkumpul dalam buku yang berjudul Rekonstruksi dan Modernisasi Lembaga Pendidikan Islam. Global Pustaka Utama, Yogyakarta.

Munir, Nizhamu. 1996. Ta'lim al Lughah al - 'Arabiyah fi al Ma'had al - Islamiyah, Darul Huda, Skripsi. 


\title{
KONSEP DASAR PENGAJARAN BAHASA ARAB
}

\author{
Fatmawati \\ Dosen prodi Pendidikan Bahasa Arab Fakultas Agama Islam \\ Universitas Muhammadiyah Makassar
}

\begin{abstract}
In every learning process, there is always a concept or planning that has been planned by the teacher, because the concept is a guide to move forward to get results which appropriate with what we expect. In the Arabic Language teaching process, the basic concept is the initial idea / planning that has been prepared to teach the Arabic language in accordance with the activity or teaching process between the educators and the learners. The teacher is the main role in Arabic Language teaching process. But it does not mean that it only depend on active teachers, while the learners are accepted to be passive in this teaching process. Teaching requires the activeness of both parties who are both subjects of teaching. In other words, the concept of teaching plays an important role in guiding educators to carry out their duties as educators in serving the learning needs of their students. Lesson plan is also intended as a first step before the learning process takes place. So that the concept of Arabic teaching can be interpreted as the process of composing the subject matter, the use of instructional media, the use of learning methods and assessment in a time allocation that will be implemented at a certain time to achieve the competence of mastery Arabic language that has been determined before
\end{abstract}

Keywords: concept, teaching, arabic language

\begin{abstract}
Abstrak
Dalam setiap proses pembelajaran yang berlangsung selalu ada konsep atau perencanaan yang telah direncanakan oleh guru, karena konsep merupakan pedoman untuk melangkah ke depan untuk mendapatkan hasil yang sesuai dengan apa yang diharapkan. Dalam pengajaran bahasa Arab konsep dasar adalah gagasan/perencanaan awal yang sudah disiapkan untuk mengajar bahasa arab sesuai dengan aktivitas atau proses pengajaran antara pendidik dan peserta didik. Kunci pokok pengajaran bahasa arab itu ada pada seorang guru. Tetapi ini bukan berarti dalam dalam proses pengajaran hanya guru yang aktif, sedangkan peserta didik pasif. Pengajaran menuntut keaktifan kedua pihak yang sama-sama menjadi subyek pengajaran. Dengan kata lain bahwa konsep pengajaran memainkan peran penting dalam memandu pendidik untuk melaksanakan tugas sebagai pendidik dalam melayani kebutuhan belajar anak didiknya. Perencanaan pengajaran juga dimaksudkan sebagai langkah awal sebelum proses pembelajaran berlangsung. Sehingga konsep pengajaran bahasa Arab dapat diartikan sebagai proses penyusunan materi pelajaran, penggunaan media pengajaran, penggunaan metode pembelajaran dan penilaian dalam suatu alokasi waktu yang akan dilaksanakan pada masa tertentu untuk mencapai kompetensi penguasaan bahasa Arab yang telah ditentukan sebelumnya.
\end{abstract}

Kata kunci: Konsep, Pengajaran, bahasa Arab 


\section{PENDAHULUAN}

$\mathrm{P}$ engajaran bahasa Arab sangat menarik sekali untuk dikaji ulang. Bukan saja karena fungsi dan esensinya bagi kehidupan komunikasi Islam, tapi karena sifatnya yang berada di tengah-tengah tradisi kependidikan yang sedang berlangsung dewasa ini memerlukan berbagai inovasi, sebagai konsekuensi logis berkembangnya sains dan teknologi. Perkembangan ilmu pengetahuan dan teknologi yang begitu pesat bagi kehidupan manusia, maka diperlukan adanya upaya pada teknisi pengajaran bahasa.

Pembelajaran bahasa diperlukan agar seseorang dapat berkomunikasi dengan baik dan benar dengan sesamanya dan lingkungannya, baik secara lisan maupun tulisan. Tujuan pembelajaran bahasa adalah untuk menguasasi ilmu bahasa dan kemahiran berbahasa

Arab, seperti muthala 'ah, muhadatsah, insya', nahwu dan sharaf, sehingga memperoleh kemahiran berbahasa yang meliputi empat aspek kemahiran, yaitu:

1. Kemahiran menyimak

Kemahiran menyimak sebagai kemahiran berbahasa yang sifatnya reseptif, menerima informasi dari orang lain (pembicara).

2. Kemahiran membaca

Kemahiran membaca merupakan kemahiran berbahasa yang sifatnya reseptif, menerima informasi dari orang lain (penulis) di dalam bentuk tulisan. Membaca merupakan perubahan wujud tulisan menjadi wujud makna.
3. Kemahiran menulis

Kemahiran menulis merupakan kemahiran bahasa yang sifatnya yang menghasilkan atau memberikan informasi kepada orang lain (pembaca) di dalam bentuk tulisan. Menulis merupakan perubahan wujud pikiran atau perasaan menjadi wujud tulisan.

4. Kemahiran berbicara

Sedangkan kemahiran berbicara merupakan kemahiran yang sifatnya produktif, menghasilkan atau menyampaikan informasi kepada orang lain (penyimak) di dalam bentuk bunyi bahasa (tuturan merupakan proses perubahan wujud bunyi bahasa menjadi wujud tuturan

Departemen Agama menjelaskan bahwa tujuan umum pembelajaran bahasa Arab adalah:

1. Untuk dapat memahami al-Quran dan hadist sebagai sumber hukum ajaran Islam.

2. Untuk dapat memahami buku-buku agama dan kebudayaan Islam yang ditulis dalam bahasa Arab.

3. Untuk dapat berbicara dan mengarang dalam bahasa Arab

4. Untuk dapat digunakan sebagai alat pembantu keahlian lain (supplementary).

5. Untuk membina ahli bahasa Arab, yakni benar-benar profesional.

Di samping itu tujuan pengajaran bahasa Arab adalah untuk memperkenalkan berbagai bentuk ilmu bahasa kepada peserta didik yang dapat membantu memperoleh kemahiran berbahasa, dengan menggunakan berbagai bentuk dan ragam bahasa 
untuk berkomunikasi, baik dalam bentuk lisan maupun tulisan, untuk tercapainya tujuan tersebut para pengajar atau ahli bahasa, pembuat kurikulum atau program pembelajaran harus memikirkan materi atau bahan yang sesuai dengan tingkat kemampuan peserta didik serta mencari metode atau teknik pengajaran ilmu bahasa dan kemahiran berbahasa arab, dan melatih peserta didik dalam kehidupan seharihari, baik kemahiran membaca, menulis dan berbicara.

Kemahiran dasar yang harus dimiliki dalam memahami bahasa Arab dalam menguasai ilmu bahasa dan kemahiran berbahasa Arab beserta kaidahnya-kaidahnya, menghafal atau menguasai kosa-kata (mufradat) beserta artinya. Kaidah-kaidah bahasa Arab dipelajari dalam mata kuliah nahwu dan sharaf. Sedangkan mufradat dapat dikuasai melalui mata kuliah muthala'ah dan muhadatsah, karena kedua mata kuliah tersebut sangat bergantung pada penguasaan kosa-kata.

Untuk menguasai kesemua kemahiran berbahasa ini dibutuhkan sebuah proses belajar mengajar yang baik, dengan memperhatikan segala aspek mulai dari perencanaan, pelaksanaan dan evaluasi. Oleh karena itu dalam tulisan ini akan dibahas tentang konsep pengajaran Bahasa Arab dengan rumusan masalah sebagai berikut:

1. Apa saja prinsip-prinsip pengajaran bahasa Arab?

2. Bagaimana pengembangan konsep dasar pengajaran bahasa Arab?

\section{PEMBAHASAN}

\section{Pengertian Konsep Dasar Pengajaran.}

Konsep dasar merupakan sebuah gagasan atau ide awal yang relatif sempurna dan bermakna. Atau bisa dikatakan juga konsep dasar merupakan peta perencanaan untuk masa depan sehingga bisa dijadikan pedoman untuk melangkah ke depan agar mendapatkan hasil baik sesuai dengan keinginan kita.

Pada umumnya konsep harus disiapkan oleh siapa saja dan apa saja profesinya agar target kita di esok hari sesuai dengan perencanaan awal dan dapat terlaksana dengan baik, dengan adanya hal ini kita dapat terbantu secara konseptual untuk melaksanakan rencana awal tadi.

Sedangkan, pengajaran merupakan perpaduan dari dua aktivitas, yaitu Aktivitas Mengajar dan Aktivitas Belajar. Aktivitas mengajar menyangkut peranan seorang guru dalam konteks mengupayakan terciptanya jalinan komunikasi harmonis antara mengajar itu sendiri dengan belajar. Jalinan komunikasi yang harmonis inilah yang mnejadi indicator suatu aktivitas/proses pengajaran itu berjalan dengan baik. Jadi, Konsep Dasar Pengajaran Bahasa Arab adalah gagasan/perencanaan awal yang sudah disiapkan untuk mengajar bahasa arab sesuai dengan aktivitas atau proses pengajaran antara pendidik dan peserta didik.

Dalam konteks pengajaran, perencanaan dapat diartikan sebagai 
proses penyusunan materi pelajaran, penggunaan media pengajaran, penggunaan metode pembelajaran dan penilaian dalam suatu alokasi waktu yang akan dilaksanakan pada masa tertentu untuk mencapai tujuan yang telah ditentukan sebelumnya.

Suatu pengajaran akan bisa disebut berjalan dan berhasil secara baik, manakala ia mampu mengubah diri peserta didik dalam arti yang luas serta mampu menumbuh kembangkan kesadaran peserta didik untuk belajar, sehingga pengalaman yang diperoleh peserta didik selama ia terlibat di dalam proses pengajaran itu dapat dirasakan manfaatnya secara langsung bagi perkembangan pribadinya.

Kunci pokok pengajaran bahasa arab itu ada pada seorang guru. Tetapi ini bukan berarti dalam dalam proses pengajaran hanya guru yang aktif, sedangkan peserta didik pasif. Pengajaran menuntut keaktifan kedua pihak yang sama-sama menjadi subyek pengajaran.

Pihak pendidik berperan sebagai pengendali dan pengarah proses pengajaran. Pendidik disebut sebagai objek (pelaku peranan pertama) pengajaran.oleh karena itu seorang pendidik menjadi pihak yang memiliki tugas, tanggung jawab dan inisiatif pengajaran. Sedangkan pihak peserta didik sebagai pihak ynag terlibat langsung sehingga ia dituntut keaktifannya dalam proses pembelajaran. Peserta didik mempunyai peran sebagai objek pengajaran kedua, Karena pengajaran itu tercipta setelah ada beberapa arahan dan masukkan dari objek pertama (pendidik) selain kesediaan dan kesiapan peserta didik itu sendiri sangat diperlukan untuk terciptanya proses pengajaran.

\section{Kinerja Mengajar}

Seorang pendidik, dimana pun dia mengajar, bertugas menyajikan ilmu yang dia miliki kepada peserta didiknya. Agar dapat memberikan ilmu tersebut ia memerlukan pengalaman, pengetahuan tentang siapa peserta didik, serta bagaimana caranya agar penyampaian ilmu tersebut bisa diterioma dengan baik. Ia harus memahami dan mendalami kompetensi dasar yang member bekal kepadanya untuk memperbaiki atau menambah terutama cara penyajian topic menjadi lebih baik, menarik, teratur, dan terpadu dengan kompetensi yang terkandung dalam materi. Hal ini merupakan bagian terpenting dari kinerja mengajar (teaching performance) seorang pengajar untuk segala jenjang pendidikan.

Kinerja mnegajar tidak hanya ditinjau dari bagaimana pendidik tersebut menjelaskan isi pelajaran, ia harus tahu bagaimana menghadapi peserta didik, membantu memecahkan masalah, mengelola kelas, menyusun bahan ajar, menentukan kegiatan kelas, menyusun asesme belajar, .menentukan metode atau media dan menjawab pertanyaan dengan bijaksana. Satu hal yang diharuskan jika seorang pendidik hendak mengajar, maka ia harus menyiapkan Rancangan Perencanaan Pembelajaran (RPP), penyusunan RPP ini terkait dengan rencana yang akan ia laksanakan sewaktu berada di ruang 
kelas. Agar Rancangan Perencanaan Pembelajaran (RPP) tersusun dengan baik, pengajar memerlukan landasan berpikir atau bekal ilmu yang mendukung penyusunan RPP tersebut. Bahkan ia harus siap berkomunikasi di kelas dengan baik, memikirkan kegiatan apa ynag harus dilakukan peserta didik agar mereka dapat mencerna seluruh materi pelajaran yang pendidik telah berikan.

Dengan demikian, menyusun Rancangan Perencanaan Pembelajaran (RPP) tak cukup dengan hanya mengikuti struktur atau lembar baku yang telah disediakan lembaga pendidikan tempat ia mengajar tapi harus mempunyai landasan berpikir yang baik agar penyusunan Rancangan Perencanaan Pembelajaran (RPP) menjadi baik dan mudah kita terpakan di ruang belajar.

Jika seorang pendidik mneyadari dan memahami pentingnya hal-hal tadi, kemungkinan besar ia dapat mmneghasilkan penbelajaran yang efektif dan menarik. Selain itu, ia menemukan inovasi dalam kegiatan belajar mengajar sehari-hari atau terkait dengan pembelajaran pada umumnya.

\section{Persiapan Pengajaran Bahasa Arab}

Tujuan pengajaran bahasa arab itu bukanlah untuk mengisi otak peserta didik dengan berbagai ilmu-ilmu yang berkaitan dengan bahasa arab, menghafalnya diluar kepala, menirukan apa yang pendidik katakana, tanpa dapat mengambil pelajaran dari pembelaran bahasa arab itu, akan tetapi dengan adanya pengajaran itu guru mengusahakan agar murid selalu terlatih menggunakan otaknya serta mengarahkannya, sehingga mampu melaksanakan tugas kewajibannya dengan sebaik-baiknya. Untuk itu pendidik harus membantu murid memahami sesuatu dan melaksanakanya serta menerapakanya dalam segala problema yang sama dengannya.

Semua pelajaran yang disampaikan oleh peserta didik harus mengandung tujuan menambah pengetahuan murid. Untuk merealisir tujuan tersebut, maka harus ada saling pengertian antara pendidik dan peserta didik. Disamping itu pendidik harus memberikan dukungan kepada peserta didik agar mereka mau berusaha memahami materi pelajaran yang telah kita (pendidik) sampaikan, serta peserta didik dapat menerapkannya.

Berikut faktor yang dapat mendukung keberhasilan pengajaran :

1. Memahami kurikulum

2. Konsep dasar pengajaran yang sempurna

3. Metode pengajaran yang baik.

4. Kemampuan peserta didik untuk dapat menerima serta memahami segala materi yang telah disampaikan dengan sabaik baiknya.

Oleh karena itu, bahwa bagaimanapun tingginya materi pelajaran yang diberikan dan dan bagaimanapun kemampuannya mengajar, pendidik tidak boleh menyajikan materi pelajaran tanpa ada nya pemikiran dan persiapan, perencanaan, atau konsep dasar yang lengkap. 


\section{Urgensi Konsep Dasar Pengajaran}

Konsep dasar pengajaran memainkan peran penting dalam memandu pendidik untuk melaksanakan tugas sebagai pendidik dalam melayani kebutuhan belajar anak didiknya. Perencanaan pengajaran juga dimaksudkan sebagai langkah awal sebelum proses pembelajaran berlangsung.

Ada beberapa urgensi konsep dasar pengajaran dalam proses belajar mengajar yaitu :

1. Sebagai petunjuk arah kegiatan dalam mencapai tujuan

2. Sebagai pola dasar dalam mengatur tugas dan wewenang bagi setiap unsur yang terlibat dalam kegiatan.

3. Sebagai pedoman bagi setiap unsur pendidik maupun peserta didik.

4. Sebagai alat ukur efektif tidaknya suatu pekerjaan, sehingga setiap saat diketahui ketepatan dan kelambatan kerja.

5. Untuk bahan penyusunan materi pelajaran agar terjadi kesimbangan dalam pengajaran.

6. Untuk menghemat waktu, tenaga, dan media. Sedangkan penerapan konsep dan prinsip pengajaran diharapkan bermanfaat untuk :

a. Menghinadari duplikasi dalam memberikan materi pelajaran. Dengan menyajikan materi pelajaran yang benar-benar relevan dengan kompetensi yang ingin dicapai, dapat dihindari terjadinya duplikasi dsan pemberian materi pelajaran yang terlalu banyak. b. Mengupayakan konsistensi kompetensi yang ingin dicapai dalam mengajarkan suatu mata pelajaran. Dengan kompetensi yang telah ditentukan secra tertulis, siapapun yang mnegajarkan mata pelajaran tertentu tidak akan bergeser dari kompetensi dan materi pelajaran yang telah ditentukan.

c. Memperjelas komunikasi dengan siswa tentang tugas, kegiatan, atau pengalaman belajar yang harus dilakukan, dan cara yang digunakan untuk menentukan keberhasilan belajar para peserta didik.

\section{Prinsip - prinsip Pengajaran Bahasa Arab}

1. Prinsip Pengajaran Secara Umum

Untuk membuat konsep dasar atau perencanaan yang baik dan dapat menyelenggarakan proses pembelajaran yang ideal, setiap pendidik harus mengetahui unsur-unsur konsep dasar pengajaran bahasa arab menjadi pembelajaran yang baik.

Berikut unsur-unsur konsep dasar pengajaran:

1. Mengidentifikasi kebutuhan siswa.

2. Mengtahui tujuan yang hendak dicapai.

3. Memahami berbagai macam strategi yang relevan digunakan untuk mencapai tujuan pembelajaran.

Bersamaan dengan hal itu peran pendidik dalam mengembangkan strategi amat penting, karena aktivitas belajar pesert didik sangat dipengaruhi oleh keaktifan, sikap dan perilaku 
pendidik dalam kelas. Jika mereka serius meperhatikan keaktifan pendidik dalam memberikan materi pelajaran, maka para peserta didik tersebut pun akan mengembangkan aktivitas-ktivitas belajarnya dengan baik, antusias, giat dan serius, serta hal yang paling penting adalah terciptanya suasana dan hasil yang sama-sama diharapkan.

Lebih jelasnya, pengembangan persiapan mengajar harus memperhatikan minat dan perhatian peserta didik terhadap materi yang dijadikan bahan kajian. Dalam hal ini peran pendidik bukan hanya transformator, tetapi harus berperan sebagai motivator yang dapat membangkitkan gairah belajar para peserta didik dengan menggunakan berbagai variasi media, dan sumber belajar yang sesuai serta menunjang pembentukan kompetensi.

2. Prinsip Pengajaran Secara Khusus.

Belajar Bahasa Arab berbeda dengan belajar bahasa ibu, oleh karena itu prinsip dasar pengajarannya harus berbeda, baik menyangkut metode (model pengajaran), materi maupun proses pelaksanaan pengajarannya. Bidang keterampilan pada penguasaan Bahasa Arab meliputi kemampuan menyimak (Mahaarah al - Istima'), kemampuan berbicara (Mahaarah alkallam), kemampuan membaca (Mahaarah al-qira'ah), dan kemampuan menulis (Mahaarah al Kitaabah).

Ada tiga prinsip pengajaran secara khusus (Bahasa Arab), yaitu :

a. Prinsip Prioritas
Dalam pembelajaran Bahasa Arab, ada prinsip-prinsip prioritas dalam penyampaian materi pengajaran, yaitu; pertama, mengajarkan, mendengarkan, dan bercakap sebelum menulis. Kedua, mengakarkan kalimat sebelum mengajarkan kata. Ketiga, menggunakan kata-kata yang lebih akrab dengan kehidupan sehari-hari sebelum mengajarkan bahasa sesuai dengan penutur Bahasa Arab.

b. Prinsip korektisitas

Prinsip ini diterapkan ketika sedang mengajarkan materi Fonetik, Sintaksis dan Semiotik Maksud dari prinsip ini adalah seorang pengajar bahasa arab hendaknya jangan hanya bisa menyalahkan para peserta didik, tetapi ia juga harus mampu melakukan perbaikan dan membiasakan pada peserta didik untuk kritis pada hal-hal berikut:

1) Korektisitas dalam pengajaran (fonetik).

2) Korektisitas dalam pengajaran (sintaksis).

3) Korektisitas dalam pengajaran (semiotik).

c. Prinsip Bertahap.

Jika dilihat dari sifatnya, ada 3 kategori prinsip berjenjang, yaitu:

1. Tahap Pengajaran Mufrodat.

2. Tahap Pengajaran Qawa'id.

3. Tahap Pengajaran Makna.

Perkembangan Konsep Dasar Pengajaran.

Pengajaran merupakan kerjasamanya dua aktivitas antar pendidik dan peserta didik dan penerapan konsep mengajar dan konsep 
belajar. Penekanany terletak pada antara keduamya yakni penumbuhan aktivitas subjek didi. Konsep tersebut dapat dipandang sebgai suatu system. Sehingga dalam system belajar ini terdapat komponen - komponen peserta didik, tujuan, materi untuk mencapai tujuan, fasilitas dan prosedur serta alat /media yang harus dipersiapkan.

Pada umumnya bahwa system pembelajaran menyangkut pengorganisasian dari perpaduan antara manusia, pengalaman belajar, fasilitas, pemeliharaan dan prosedur yang mengatur interaksi perilaku pengajaran untuk mencapai sebuah tujuan pembelajaran.

Demikian juga dengan system pengajaran dimana komponen perencanaan pengajaran, bahan ajar, tujuan materi, dan metode serta penilaian dan langkah mengajar akan berhubungan dengan aktivitas belajar untuk m,necapai tujuan. Kenyataan bahwa dalam proses pembelajaran terjadi pengorganisasian, pengelolaan dan transformasi informasi oleh dan dari guru kepada siswa.

\section{Tingkatan-tingkatan}

dalam

\section{Pembelajaran Bahasa Arab}

Perlu diperhatikan dalampembel ajar bahasa Arab dengan tujuan untuk menhilangkan kesan bahwa bahasa arab itu sulit dan memusingkan maka guru harus mengerti tingkatan murid yang sedang diajar, agar bisa memberikan materi sesuai dengan tingkat siswa pada saat itu.

Pemberian materi yang sesuai akan mempercepat pemahaman siswa, jangan sampai pada saat siswa masih pada tahap pemula (mubtadi'in) dalam mempelajari bahasa Arab, guru memberikan materi yang terlalu sulit seperti mengarang, bercerita dalam bahasa Arab tentu itu akan membuat siswa yang baru belajar bahasa Arab akan merasa sangat kesulitan, sehingga timbullah kefahaman pada diri siswa bahwa bahasa Arab itu sulit, begitu juga sebaliknya pemberian materi yang terlalu ringan kepada siswa yang sudah pada tingkat mahir (mutaqodimin) akan membuat siswa merasa cepat bosan karena meteri itu sudah dia kuasai, pengenalan awal terhadap tingkatan siswa akan sangat membantu seorang guru dalam memberikan sebuah materi yang cocok, hal ini sesuai dengan yang dikatakan Yusuf bahwa pembelajaran bahasa Arab perlu dipersiapkan materi dengan baik yang disesuaikan dengan taraf perkembangan anak didik

Untuk menghindari kesan bahwa belajar bahasa Arab itu sulit maka yang harus kita laksanakan adalah:

1. Mengajarkan bahasa Arab percakapan dengan kata-kata yang sederhana dan mudah dimengerti oleh peserta didik

2. Menggunakan alat peraga atau alat bantu, hal ini penting agar pembelajaran menarik, bergairah, dan mudah difahami

3. Mengaktifkan seluruh panca indra anak didik, lidah dilatih dengan percakapan, mata dilatih dengan membaca, dan tangan dilatih dengan menulis dan mengarang 
Dalam Pembelajaran bahasa Arab telah kita ketahui bahwa tingkatan pembelajaranbahasa Arab terdiri atas:

1. Mubtadi'in (pemula) ini adalah tingkatan yang paling awal dalam pembelajaran bahasa arab, dan biasanya materi yang paling cocok untuk tingkatan ini adalah: menghafalkan mufrodat, percakapan yang sederhana, dan mengarang terarah (insya' muwajahah) ini biasanya digunakan pada level bawah karena ia mencakup kegiatan mengarang yang dimulai dari merangkai huruf, kemudian kata dan kalimat

2. Mutawasitin (menengah) ketika siswa pada tingkatan ini berarti dia sudah mendapatkan beberapa materi tentang bahasa Arab, dan tugas seorang guru pada saat itu adalah memberi penguatan terhadap materi-materi yang sudah didapatkan oleh siswa, sehingga bisa mahir dalam materi tersebut

3. Mutaqodimin (mahir) pada tingkatan ini siswa sudah mulai mahir terhadap materi-materi berbahasa Arab dan materi yang sesuai bagi siswa yang sudah pada tingkatan ini adalah mengarang bebas (insya hur) ini biasanya digunakan pada level tingkat tinggi karena disitu kentrampilan, kreatifitas dari seorang penulis sangat diandalkan.

Adapun terdapat pendapat lain dalam tingkatan-tingkatan dalam pembelajaran bahasa Arab, yaitu tingkat pemula diterjemahkan dengan al-Marhalat al-Ûla, dalam bahasa Inggris disebut dengan Elementary Level. Sementara tingkat menengah dalam bahasa Arab diterjemahkan dengan al-Marhalat alMutawassithah, dalam bahasa Inggris disebut dengan Intermediate Level.

Menurut Dr. Ali Al-Hadîdi, istilah tingkat pemula atau menengah dalam dunia pembelajaran bahasa, termasuk bahasa Arab, dapat diukur dari dua aspek: pertama, aspek jumlah penguasaan mufradât siswa. Untuk tingkat pemula, mufradât yang harus dikuasainya adalah 0 s/d. 1.000 kata, demikian juga untuk tingkat menengah, (1.000 s/d. 2.000 kata). Kedua, dari segi jumlah jam pelajaran. Untuk tingkat pemula, jumlah jam pelajaran yang harus dilalui mencapai 0 s/d. 250 jam; 200 jam dihabiskan secara formal di sekolah dan 50 jam untuk tugas dll. Jumlah dan alokasi jam di atas, juga berlaku untuk "tingkat menengah" yaitu 250 jam pelajaran: yang terdiri dari: 200 jam di kelas (dalam bimbingan guru), dan selebihnya di luar kelas, seperti tugas harian (minimal dua jam dalam sehari) baik secara mandiri maupun berkelompok.

Memperhatikan batasan di atas, dapat diketahui bahwa dikatakan tingkat pemula jika telah menguasai mufradat sejumlah 1.000 kata. Sementara untuk beranjak pada tingkat menengah harus menguasai 2.000 mufaradat. Di sisi lain, jumlah jam pelajaran yang harus dilewati mencapai 250 jam.

Berdasarkan batasan di atas, istilah pemula atau menengah tidak 
harus dipahami secara formal, seperti menyamakan pemula dengan SD atau MI, serta SLTP atau MTs dan SLTA atau Madrasah Aliyah dengan menengah, karena masing-masing level tersebut diukur dengan penguasaan sejumlah kosa kata dan sejumlah jam pelajaran yang telah dilalui. Maka boleh saja seseorang yang telah berumur 30 tahun namun baru mulai belajar bahasa disebut sebagai pemula, atau sebaliknya siswa yang baru berumur 10 tahun, tapi telah menguasai kosa kata dan jam pelajaran setingkat menengah disebut sebagai level menengah.

\section{Unsur-unsur yang terkait dalam proses belajar mengajar terdiri dari:}

\section{a) Motivasi belajar siswa}

Dalam pembelajaran harus ada upaya-upaya agar motivasi yang sudah ada pada diri pembelajaran tetap terpelihara dan ditingkatkan karena motivasi berguna untuk menghubungkan pengalaman yang lama dengan bahan pelajaran yang baru, sebab setiap siswa datang ke kelas dengan latar belakang yang berbedabeda. Dengan motivasi, siswa tidak mengalami dalam belajar dan merasa terdorong untuk mempelajari bahanbahan baru.

\section{b) Bahan ajar}

Bahan belajar yang tersedia harus mendukung bagi pencapaian tujuan belajar siswa karena itu penggunaan bahan belajar harus selektif dan disesuaikan dengan komponenkomponen lainnya.

\section{c) Alat bantu ajar}

Suasana belajar perlu dikembangkan agar masing-masing siswa bisa kompetitif. Sebab dengan kompetitif yang sehat akan memungkinkan setiap siswa dapat berprestasi secara maksimal dan dapat mencapai prestasi yang setinggi mungkin.

\section{d) Suasana belajar}

Suasana belajar penting artinya bagi kegiatan belajar. Suasana yang menyenangkan dapat menumbuhkan kegairahan belajar, sedangkan suasana yang kacau, ramai, tak tenang dan banyak gangguan, sudah tentu tidak menunjang kegiatan belajar yang efektif. Karena itu, guru dan siswa senantiasa dituntut agar menciptakan suasana lingkungan belajar yang baik dan menyenangkan, menantang dan menggairahkan. Hal ini berarti bahwa suasana belajar turut menentukan motivasi, kegiatan, keberhasilan belajar siswa.

\section{e) Kondisi subyek yang belajar}

Kondisi subyek dapat dibedakan atas kondisi fisik ataupun psikis, kondisi fisik meliputi ukuran tubuh, kekuatan tubuhnya, kesehatannya, aspirasinya dan harapannya oleh karena itu kondisi siswa perlu diperhatikan. Dari kelima unsur inilah yang bersifat dinamis itu, yang sering berubah, menguat atau melemah dan yang mempengaruhi proses belajar tersebut.

\section{Unsur-unsur dinamis pada guru meliputi:}

\section{a) Motivasi membelajarkan Siswa}

Guru harus memiliki motivasi untuk membelajarkan siswa. motivasi 
itu timbul dari kesadaran yang tinggi untuk mendidik para peserta didik agar lebih baik, jadi guru harus memiliki hasrat untuk menyiapkan siswa menjadi pribadi yang memiliki pengetahuan dan kemampuan.

\section{b) Kondisi Guru Siap}

\section{Membelajarkan Siswa}

Guru perlu memiliki

kemampuan dalam proses pengajaran selain kemampuan dalam proses pengajaran selain kemampuan kepribadian dan kemampuan kemasyarakatan. Maka guru perlu berupaya meningkatkan kemampuannya agar senantiasa berada dalam kondisi siap membelajarkan siswa.

\section{Tujuan Mata Pelajaran Bahasa} Arab

Mata pelajaran bahasa arab merupakan suatu mata pelajaran yang diarahkan untuk mendorong, membimbing, mengembangkan dan membina kemampuan serta menumbuhkan sikap positif terhadap bahasa Arab baik Reseptif maupun Produktif. Kemampuan Resertif yaitu kemampuan untuk memahami pembicaraan orang lain dan memahami bacaan. Kemampuan Produktif yaitu kemampuan menggunakan bahasa sebagai alat komunikasi baik secara lisan maupun tulis. Kemampuan berbahasa arab serta sikap positif terhadap bahasa arab tersebut sangat penting dalam membantu memahami sumber ajaran islam yaitu Al-Qur'an dan Hadits, serta kitab-kitab bahasa Arab yang berkenaan dengan islam bagi peserta didik.
Untuk itu bahasa Arab di Madrasah dipersiapkan untuk pencapaian kompetensi dasar berbahasa, yang mencakup empat keterampilan berbahasa yang diajarkan secara integral, yaitu menyimak, berbicra, membaca dan menulis. Meskipun begitu, pada tingkat pendidikan dasar (Elementary) dititik beratkan pada kecakapan menyimak dan berbicara sebagai landasan berbahasa. Pada tingkat pendidikan menengah (Intermediate), keempat kecakapan berbahsa diajarkan secara seimbang. Adapun pada tingkat pendidikan lanjut (Advanced) dikonsentrasikan pada kecakapan membaca dan menulis, sehingga peserta didik diharapkan mampu mengakses berbagai referensi bahasa Arab.

\section{PENUTUP}

Konsep dasar dapat diartikan sebagai proses penyusunan materi pelajaran, penggunaan media pengajaran, penggunaan metode pembelajaran dan penilaian dalam suatu alokasi waktu yang akan dilaksanakan pada masa tertentu untuk mencapai tujuan yang telah ditentukan sebelumnya.

Suatu pengajaran akan bisa disebut berjalan dan berhasil secara baik, manakala ia mampu mengubah diri peserta didik dalam arti yang luas serta mampu menumbuh kembangkan kesadaran peserta didik untuk belajar, sehingga pengalaman yang diperoleh peserta didik selama ia terlibat di dalam proses pengajaran itu dapat dirasakan manfaatnya secara langsung bagi perkembangan pribadinya. 
Kinerja pengajaran tidak hanya dilirik dari bagaimana pendidik tersebut menjelaskan isi pelajaran, ia harus tahu bagaimana menghadapi peserta didik, membantu memecahkan problema, mengelola kelas, menyusun bahan ajar, menentukan kegiatan kelas, menentukan metode atau media dan menjawab pertanyaan dengan sistematis.

Tujuan utama pengajaran bahasa arab itu bukanlah untuk mengisi otak peserta didik dengan berbagai ilmuilmu yang berkaitan dengan bahasa arab, menghafalnya diluar kepala, menirukan apa yang pendidik katakan, tanpa dapat mengambil pelajaran dari pembelaran bahasa arab itu, akan tetapi dengan adanya pengajaran itu pendidik mengusahakan agar murid selalu terlatih menggunakan otaknya serta mengarahkannya, sehingga mampu melaksanakan tugas kewajibannya dengan sebaik mungkin.

\section{DAFTAR PUSTAKA}

Abu bakar Muhammad. 1997. Metode Khusus Pengajaran Bahasa Arab, Usaha Nasional, Surabaya.

Abdul Majid. 2011. Perencanaan Pembelajaran, PT. Rosdakarya, Bandung.

Ahmad Rohani dan Abu ahmadi. 1995. Pengelolaan Pengajaran, Jakarta, PT.Rineka Cipta.

Deni Darmawan, Konsep Dasar Pembelajaran.pdf

Dewi Salma. 2009. Prinsip Desain Pembelajaran, Jakarta: Kencana.
Hamalik Oemar. 2001. Perencanaan Pengajaran Berdasarkan Pendekatan Sistem, PT. Bumi Aksara, Bandung.

Roestiya. 2008. Strategi Belajar Mengajar, Jakarta, PT. Rineka Cipta.

Ahmad Rohani dan Abu ahmadi. 2011. Pengelolaan Pengajaran, Jakarta, PT.Rineka Cipta. Dewi Salma, Prinsip Desain Pembelajaran, Jakarta: Kencana, 2009. Hlm. 3

Abu bakar Muhammad. 2011. Metode Khusus Pengajaran Bahasa Arab, Usaha Nasional, Surabaya : 1997 Abdul Majid, Perencanaan Pembelajaran, PT. Rosdakarya, Bandung. 


\title{
METODE PERMAINAN EDUKATIF DALAM PEMBELAJARAN BAHASA ARAB
}

\author{
Nasruni \\ Dosen Program Studi Pendidikan Bahasa Arab Fakultas Agama Islam \\ Universitas Muhammadiyah Makassar
}

\begin{abstract}
Games of Language or Educative Games are the way of learning Arabic through Games. Game of language is not just as additional activity to having fun, but it can be classified as the way in teaching wich is have the aim to give the learner the opportunity to apply their language skills. In the process of teaching language, educational games are performed in various forms, one of that is based on purpose. Educative games are very usefull in recovery, inauguration, and enrichment activities in learning. Besides that, the reality proves that most learners are still weak and have the problem in speaking, writing, and listening skill. These weakness can be overcome gradually by a well designed of the Games . If language teaching does not take a good steps to overcome these weaknesses, learners will always find it difficult to learn the language.
\end{abstract}

\section{Keywords: Implementation, Educative Games, Learning Arabic}

\begin{abstract}
Abstrak
Permainan bahasa atau permainan edukatif merupakan cara mempelajari bahasa Arab melalui permainan. Permainan bahasa bukan merupakan aktivitas tambahan untuk bergembira semata, tetapi dapat digolongkan dalam pengajaran yang bertujuan memberikan kesempatan ke pada peserta didik untuk mengaplikasikan kemahiran bahasa yang telah dipelajari. Dalam pengajaran bahasa, permainan edukatif dilakukan dalam berbagai bentuk, salah satunya berdasarkan tujuan. Permainan edukatif sangat berguna bagi aktivitas pemulihan, pengukuhan, dan pengayaan dalam pembelajaran. Selain itu, kenyataan menunjukkan bahwa kebanyakan peserta didik masih lemah dalam menghadapi masalah komunikasi, menulis, dan mendengar. Kelemahan ini dapat diatasi sedikit demi sedikit melalui aktivitas permainan yang dirancang dengan baik dan benar. Jika pengajaran bahasa tidak mengambil langkah yang baik untuk mengatasi kelemahan ini maka peserta didik selamanya menemui kesulitan dalam belajar bahasa.
\end{abstract}

\section{Kata kunci : Penerapan, Permainan Edukatif, Pembelajaran Bahasa Arab}




\section{PENDAHULUAN}

$\mathrm{S}$ ejarah pengajaran bahasa Arab di Indonesia tidak terlepas dari sejarah kehadiran agama Islam itu sendiri di negeri ini. Sebagai bangsa yang mayoritas penduduknya Muslim, pengajaran bahasa Arab di Indonesia tampaknya lebih didasarkan pada alasan-alasan agama dari pada alasan lainnya seperti alasan ekonomi dan politik. Bahasa Arab dipelajari dalam semangat bahasa alQur'an dan al-hadis serta literatur keislaman lainnya. Kondisi tersebut tampak jelas dalam proses pengajaran ajaran Islam lainnya yang dilakukan di pesantren-pesantren tradisional. ${ }^{1}$

Pembelajaran bahasa Arab sudah lama dilakukan di Indonesia, namun hasilnya belum sepenuhnya maksimal. Berbagai problem masih sering bermunculan dan hampir jarang terpecahkan. $^{2} \quad$ Permasalahan perkembangan bahasa Arab yang masih cenderung stagnan ini belum terselesaikan, bahasa Arab dihadapkan pada berbagai tantangan. Diantaranya adalah arus globalisasi yang menyebabkan pelajar lebih memilih belajar bahasa Inggris, Jerman, dan Prancis sebagai bahasa asing ketimbang bahasa Arab. ${ }^{3}$

Kurangnya inovasi pendidik, praktisi, mahasiswa, pemerhati, dan pengkaji bahasa Arab juga menjadi penyebab

${ }^{1}$ Lihat Hasyim Haddade, Reformulasi Kurikulum Bahasa Arab (Cet. I; Makassar: Alauddin Press, 2011), h. 35.

${ }^{2}$ Fathul Mujib dan Nailur Rahmawati, Metode Permainan-permainan Edukatif dalam Belajar bahasa Aarab ( Cet. I; Jogjakarta: Diva Press, 2011), hlm. 6.

${ }^{3}$ Uli Nuha, Metodologi Super Aktif Pembelajaran Bahasa Arab (Jogjakarta: Diva Press, 2012), hlm. 21. stagnasi pendidikan bahasa Arab sekarang. Indikasi dari keadaan ini sangat jelas; sedikitnya tulisan bahasa Arab baik secara teoritis maupun parktis tentang model, tips maupun kreativitas pembelajaran dan pengajaran yang dapat membantu guru secara teknisi di lapangan. ${ }^{4}$

Tantangan lain yang dihadapi bahasa Arab, menurut beberapa penilaian bahwa bahasa Arab menjadi salah satu pelajaran yang ditakuti oleh pelajar Indonesia. Mereka masih menganggap dan mengklaim bahasa Arab sebagai pelajaran yang sulit dibanding bahasa Asing lainnya. $^{5}$ Tanggapan tersebut muncul akibat penyeleksian materi, urutan, dan tata cara penyajiannya tidak sesuai bagi pelajar Indonesia.

Tantangan berikutnya adalah problematika metodologis, terkait dengan metode pembelajaran yang digunakan oleh guru dalam proses belajar dan mengajar. Metode pembelajaran bahasa Arab pada dasarnya telah berkembang pesat, tetapi praktik di lapangan menunjukkan belum adanya progres yang berarti. ${ }^{6}$

Mahmud Yunus dalam Azhar Arsyad mengatakan bahwa metode lebih penting dari subtansi. ${ }^{7}$ Akan tetapi, penguasaan

${ }^{4}$ Fathul Mujib dan Nailur. Permainan Edukatif Pendukung Pembelajaran Bahasa Arab (2) (Jogjakarta: Diva Press, 2012), hlm. 6.

${ }^{5}$ Ibid,

${ }^{6}$ Kebahasaan, http://abiebrambram.blogspot.com/2012/09/permai nan-dalam-pembelajaran-bahasa-arab.html (3 januari 2013).

${ }^{7}$ Azhar Arsyad, Bahasa Arab dan Metode Pengajarannya Beberapa Pokok Pikiran (Cet. III; Yogyakarta: Pustaka Pelajar, 2010), hlm. 66. 
materi atau subtansi tidak bisa diabaikan. Keduanya saling membutuhkan. Muhammad Abdul Qadir Ahmad menjelaskan bahwa metode adalah untuk membantu atau menjelaskan subtansi. Tidak ada faidahnya dari metode yang baik tanpa adanya materi. Dan metode yang mengantar kepada pemahaman peserta didik terhadap materi. Olehnya itu, metode dan materi adalah dua unsur yang sangat penting untuk keberhasilan guru dalam pembelajaran. ${ }^{8}$

Penggunaan metode pembelajaran yang selama ini dipakai dan digunakan oleh guru dalam proses pembelajaran bukanlah sebuah hal yang asal pakai. Akan tetapi, dalam penggunaannya harus melalui tahap penilaian, dan pemilihan yang ketat. Dalam memilih dan menentukan metode guru melakukan seleksi sehingga hasilnya sesuai dengan perumusan tujuan pembelajaran yang telah ditargetkan. ${ }^{9}$

Pemilihan dan penentuan metode yang digunakan oleh seorang guru dalam pembelajaran harus berkaitan dengan nilai strategi metode, efektivitas penggunaan metode, dan lain sebagainya. Dalam proses pembelajaran, tentunya terjadi sebuah interaksi edukatif antara guru dan siswa sebagai sasaran didik. Oleh karen itu, dalam penyampaian bahan dan materi pelajaran, seorang guru harus menggunakan strategi pembelajaran yang tepat. Di sinilah kelahiran metode menempati posisi yang sangat sentral dan

${ }^{8}$ Muhammad Abdul Qadir Ahmad, Thuruq Ta'lim al-Lugah al-Arabiyyah (cet. I; Kairo-Mesir : Maktabah an-Nahdhah al-Misriyyah, 1979), hlm. 6.

${ }^{9}$ Ulin, Nuha. op. cit., hlm. 162. urgen dalam penyampaian bahan dan materi pelajaran. ${ }^{10}$

Meskipun bahasa Arab sudah masuk dalam mata pelajaran tersendiri di berbagai sekolah, tidak semudah membalikkan telapak tangan peserta didik dapat menyerap, memahami, serta menguasai materi pembelajaran bahasa Arab yang telah diajarkan. Banyak peserta didik yang merasa kesulitan dalam menyerap dan memahami materi bahasa Arab yang telah diajarkan oleh gurunya.

Salah satu cara untuk menciptakan suasana yang nyaman dan menyenangkan dalam pembelajaran adalah dengan bermain. Penulis berasumsi ketika peserta didik senang dan merasa nyaman dalam belajar mereka tidak akan merasa terbebani dengan materi yang diberikan sehingga mempermudah mereka menyerap materi dan memahami bahasa Arab bahkan sederet hafalan yang diberikan. Dalam hal ini, dibutuhkan media pembelajaran yang dapat menarik minat dan mengaktifkan semua siswa dalam proses belajar-mengajar bahasa Arab. Dengan kata lain, peran permainan tidak kalah pentingnya dengan peran kompetensi guru yang memadai dalam proses belajar. Hal ini dikarenakan permainan dapat memberikan peluang yang besar untuk memperoleh hasil pembelajaran yang maksimal.

Permainan edukatif yang diintegrasikan dalam pengajaran seharusnya mempunyai beberapa tujuan sebagai berikut:

1. Merangsang interaksi verbal peserta didik

\footnotetext{
${ }^{10}$ Ibid., hlm. 163.
} 
Dalam permainan, para peserta didik diminta mengungkapkan pendapat masing-masing. Selain itu mereka juga diminta untuk memberikan alasan-alasan tertentu yang berkaitan dengan pelajaran. Para peserta didik perlu terlibat sepenuhnya dalam permainan ini. Sehingga setiap peserta atau kelompok bermain merasa diperlukan oleh kelompok itu, serta diharapkan bersedia berkomunikasi dan mengungkapkan pendapat masingmasing. ${ }^{11}$

2. Menambah kefasihan dan kepercayaan diri peserta didik

Permainan sangat membantu dalam upaya meningkatkan kemampuan bahasa (komunikasi) peserta didik. Selain itu, permainan ini membantu peserta didik yang memiliki kesulitan dalam belajar dengan metode tradisional. Sehingga peserta didik yang bersangkutan menjadi mudah dalam belajar serta mendapatkan rasa aman dan percaya diri. Sebab ciri permainan itu bersifat luwes dan dapat dipakai dalam berbagai tujuan pendidikan.

Permainan edukatif bisa digunakan sebagai salah satu cara untuk meningkatkan kefasihan berbahasa dan kepercayaan diri peserta didik. Bahasa yang digunakan dalam suatu permainan tidak harus diorentasikan pada struktur tertentu. Namun, fungsi bahasa itu bisa juga melibatkan seluruh unsur dan

\footnotetext{
${ }^{11}$ Ibid., hlm. 40.
}

keterampilan bahasa yang berbedabeda.

3. Menyediakan Konteks Pembelajaran

Permainan edukatif seharusnya membawa perkembangan dan hubungan positif dalam setiap pribadi individu yang terlibat bukan saja antara peserta didik dengan peserta didik, tetapi juga antara peserta didik dengan guru. Permainan edukatif seharusnya membantu mempererat hubungan dan kerja sama antara mereka. Hal ini merupakan suasana yang sehat dan penting serta bermanfaat bagi para peserta didik. Khususnya mereka yang memiliki kecenderungan pemalu, pasif, dan individualis di dalam kelas. Dalam permainan mereka dapat menunjukkan semangat, melatih keberanian, dan terlibat secara penuh dalam setiap aktivitas permainan yang dilakukan.

4. Alat Mengikis Rasa Bosan

Sering kali peserta didik merasa bosan merasa bosan, mengantuk, dan lapar di dalam kelas dalam beberapa waktu dan jam tertentu. Misalnya, pada waktu menjelang tengah hari atau dalam situasi yang tidak kondusif. Dalam keadaan yang demikian, tentu sulit dibayangkan keadaan guru untuk dapat menyampaikan meteri tata bahasa dan aspek-aspek pemahaman materi pelajaran bahasa dengan efektif.

Begitu juga dengan aktivitas kelas yang melibatkan penulisan karangan dan pembentukan kalimat, aktivitas istima', kalām, dan lain sebagainya. $\mathrm{Di}$ sinilah letak 
pentingnya permainan edukatif.

Permainan edukatif dapat menimbulkan perasaan gembira para siswa dan menyebabkan mereka menjadi lupa terhadap rasa lapar, serta perasaan lesu dan mengantuk. Permainan dapat mewujudkan komunikasi kondusif dalam bentuk aktivitas yang dirancang untuk mencapai tujuan pembelajaran apabila berhadapan dengan situasi yang tidak kondusif itu. $^{12}$

Permainan harus dirancang untuk mengubah situasi dan kondisi yang tidak bersahabat dengan aturan yang adil dan kompetisi yang merangsang peserta didik untuk bersaing secara sehat. Dengan demikian, peserta didik dilatih berhadapan dengan interaksi kehidupan permainan yang telah didesain dengan baik.

5. Sebagai Alat Pemulihan, Pengukuhan, dan Pengayaan

Setelah pengajaran selesai, guru seharusnya melakukan penguatan. Hal ini mengingat latihan yang dijalankan secara terus-menerus mungkin membosankan bagi peserta didik. Namun, bagaimana pun, aktivitas pengukuhan masih bisa diteruskan dengan latihan tata bahasa yang diperkenalkan dalam berbagai bentuk aktivitas permainan.

Sebagai aktivitas pengayaan, peserta didik yang lemah bisa digabung dengan peserta didik yang cerdas melalui permainan yang dijalankan. Namun mereka (peserta didik yang lemah) harus diberikan

\footnotetext{
${ }^{12}$ Ibid., hlm. 46
}

tugas yang mudah dan sesuai dengan tingkat serta kemampuan mereka. Bagi peserta didik yang cerdas, permainan dalam aktivitas pengayaan yang dapat menambahkan kemahiran, pengetahuan, dan pengalaman mereka.

\section{PEMBAHASAN}

\section{a. Pengertian Metode Permainan Edukatif}

Metode permainan edukatif terdiri atas tiga kata, yaitu; metode, permainan, dan edukatif. Kata metode secara harfiah berarti "cara". Dalam pemakaian yang umum, metode diartikan sebagai cara melakukan suatu kegiatan atau pekerjaan menggunakan fakta dan konsep secara sistematis. $^{13}$ Metode juga berarti sekumpulan cara yang dipergunakan untuk mencapai tujuan-tujuan pembelajaran yang telah ditetapkan. Metode adalah rencana menyeluruh yang berkenaan dengan penyajian materi bahasa secara teratur, tidak ada satu bagian yang bertentangan dengan yang lain dan semuanya berdasarkan atas approach yang telah dipilih. ${ }^{14}$

Kata permainan berasal dari kata main, yang berarti berbuat untuk menyenangkan hati atau melakukan perbuatan untuk menyenangkan hati dengan alat atau tidak. ${ }^{15}$ Pendapat lain

\footnotetext{
${ }^{13}$ Muhibbin Syahlm. Psikologi Pendidikan dengan Pendekatan Baru (Bandung: Remaja Rosda Karya, 2006), hlm. 201.

${ }^{14}$ Azhar Arsyad, op. cit., hlm. 19.

${ }^{15}$ Tim Penyusun Kamus Bahasa Indonesia, Kamus Bahasa Indonesia (Jakarta: Pusat Bahasa Departemen Pendidikan Nasional, 2008), hlm. 897.
} 
menyebutkan bahwa bermain berasal dari bahasa Inggris, yaitu play. Dalam konteks ini, bermain diartikan sebagai suatu kegiatan yang dilakukan untuk kesenangan yang ditimbulkannya, tanpa mempertimbangkan hasil akhir. Bermain dilakukan secara sukarela dan tidak ada paksaan atau tekanan dari luar. Sedangkan menurut Bettelheim, kegiatan bermain adalah kegiatan yang tidak mempunyai peraturan lain kecuali yang ditetapkan pemain sendiri dan tidak ada hasil akhir yang dimaksudkan hasil luar. ${ }^{16}$

Menurut Santrok sebagaimana yang dikutip oleh Muhammad Fadilah, mengatakan permainan ialah kegiatan yang menyenangkan yang dilaksanakan untuk kepentingan kegiatan itu sendiri. Menurutnya permainan memungkinkan anak melepaskan energi fisik yang berlebihan dan membebaskan perasaanperasaan yang terpendam. ${ }^{17}$ Dengan bermain, perasaan peserta didik akan menjadi bahagia sehingga akan mengalami kenyamanan dalam melakukan segala kegiatan pembelajaran.

Sedangkan kata edukatif dalam Kamus Besar Bahasa Indonesia adalah bersifat mendidik dan berkenaan dengan pendidikan. ${ }^{18}$ Kunci utama suatu permainan dapat dikatakan edukatif adalah apabila permainan itu memiliki nilai guna, efektivitas, dan efesiensi yang

\footnotetext{
${ }^{16}$ Muhammad Fadilah dkk, Pendidikan Karakter Usia Dini: Konsep \& Aplikasinya dalam PAUD (Cet. I; Jogjakarta: Ar-Ruzz Media, 2013), hlm. 147.

${ }^{17}$ Ibid., 146, Bandingkan, John W Santrock, Life-Span Development; Perkembangan Masa Hidup (Jakarta: Erlangga, 2002), hlm. 272.

${ }^{18}$ Departemen Pendidikian Nasiona,l op. cit., hlm. 218.
}

mengarahkan proses mendidik secara positif. Hal ini dapat terjadi jika suatu permainan dapat dikontrol dan digunakan dengan tepat. Sebab, permainan akan berdampak atau memberikan pengaruh negatif apabila tidak ada latar belakang 'mendidik" atau mengajak dan mengarahkan peserta didik menuju kehidupannya yang lebih baik. Di sinilah konteks inti permainan yang sesungguhnya, yakni sebagai objek yang memberikan efek kesenangan dan mendukung terwujudnya motivasi positif pada peserta didik. Dengan kata lain, permainan sebagai upaya mempengaruhi kebutuhan psikologis peserta didik. ${ }^{19}$

Dari beberapa pengertian di atas, penulis menyimpulkan permainan edukatif adalah permainan yang memiliki unsur mendidik yang didapatkan dari sesuatu yang ada dan melekat serta menjadi bagian dari permainan itu sendiri. Selain itu permainan juga memberi rangsangan ataupun respon positif terhadap indera pemainnya. Unsur edukatif dalam permainan adalah keseimbangan. Keseimbangan permainan tergantung pada maksud dan tujuan dari pembuatan atau penciptaan permainan itu sendiri.

Berkaitan dengan metode pembelajaran bahasa Arab, makna permainan edukatif dalam tulisan ini adalah permainan bahasa. Permainan bahasa merupakan cara mempelajari bahasa Arab melalui permainan. Permainan bahasa bukan merupakan aktivitas tambahan untuk bergembira semata, tetapi dapat digolongkan dalam

${ }^{19}$ Fathul Mujib dan Nailur, Metode

Permainan-permainan Edukatif op. cit., hlm. 31. 
pengajaran yang bertujuan memberikan kesempatan ke pada peserta didik untuk mengaplikasikan kemahiran bahasa yang telah dipelajari. Permainan bahasa bertujuan memperoleh kesenangan dan melatih keterampilan berbahasa. Jika suatu permainan menimbulkan kesenangan tetapi tidak memperoleh keterampilan berbahasa, maka permainan tersebut bukan termasuk permainan bahasa. Sebaliknya, apabila suatu kegiatan bertujuan melatih keterampilan berbahasa, namun tidak ada unsur kesenangan, maka kegiatan itu bukan termasuk permainan bahasa. $^{20}$ Dengan demikian, suatu permainan dapat disebut permainan bahasa apabila mengandung unsur kesenangan dan melatih keterampilan berbahasa.

Dari beberapa uraian tentang hakikat metode permainan edukatif, penulis menyimpulkan bahwa metode permainan edukatif adalah cara mengajarkan bahasa Arab dengan berbagai macam bentuk permainan, baik permainan yang menggunakan alat maupun tidak. Inti pada metode permainan edukatif adalah sebagai objek yang memberikan efek kesenangan dan mendukung terwujudnya motivasi positif pada peserta didik sehingga tujuan pembelajaran yang diinginkan dapat terwujud. Untuk disebut permainan bahasa, harus memenuhi dua syarat, yaitu menggembirakan dan melatih keterampilan berbahasa.

Pembelajaran memang tidak selalu membutuhkan permainan, dan permainan sendiri tidak selalu mempercepat proses pembelajaran. Akan tetapi, permainan yang dimanfaatkan dengan bijaksana dapat menambah variasi, semangat, dan minat pada sebagian program belajar.

Menurut Suyanti, permainan yang benar dapat membuat pembelajaran menjadi menyenangkan dan menarik, menguatkan pembelajaran, bahkan bisa dijadikan sebagai ujian. Di tengah permainan, seseorang menjadi sangat dekat dengan kekuatan penuh. Kesenangan bermain yang tidak terhalang mampu melaksanakan segala macam endorfin positif dalam tubuh, melatih kesehatan dan membuat merasa hidup sepenuhnya. Bagi banyak orang, ungkapan kehidupan dan kecerdasan kreatif yang paling tinggi di dalam diri mereka tercapai dalam sebuah permainan. Permainan dalam belajar (learning games) yang mampu menciptakan atmosfer menggembirakan dan membebaskan kecerdasan penuh serta tidak terhalang dapat memberi banyak sumbangan. $^{21}$

Bermain mengandung aspek kegembiraan, kelegaan, kenikmatan yang intensif, bebas dari ketegangan atau kedukaan, dan bersifat memerdekakan jiwa. Permainan sangat erat dengan ekspresi diri spontanitas, serta melatih pribadi untuk siap melewati persaingan, menerima kemenangan sekaligus siap menerima kekalahan, dan aktualisasi diri. Oleh karena itu, permainan bersifat mendewasakan peserta didik. Melalui bermain, peserta didik belajar banyak tentang kehidupan, baik itu belajar kemandirian, keberanian, sosialisasi,

\footnotetext{
${ }^{21}$ Ibid., hlm. 35.
}

${ }^{20}$ Ibid., hlm. 32 . 
kepemimpinan, dan menyadari arti eksistensi dirinya.

Dave Meier dalam The Accelerated Learning Handbook sebagaimana yang dikutif oleh Fathul Mujib, mengatakan bahwa kata fun (menyenangkan) berarti membuat suasana belajar dalam keadaan gembira. Kegembiraan disini berarti bangkitnya minat, adanya keterlibatan penuh serta terciptanya makna, pemahaman dan nilai yang membahagiakan bagi siswa. Itu semua merupakan kegembiraan yang dapat melahirkan sesuatu yang baru. Penciptaan kegembiraan ini jauh lebih penting daripada segala teknik atau metode atau media yang dipilih untuk digunakan dalam proses pembelajaran. ${ }^{22}$

Beberapa riset mutakhir tentang otak manusia menunjukkan hasil luar biasa berkaitan dengan learning dan brain. Misalnya, Peter Kline dalam The Everyday Genius, mengatakan bahwa proses belajar dapat berlangsung sangat efektif apabila seseorang brada dalam keadaan fun. Baak Accelarated Learning asal Bulgaria, Georgi Lazanov, merumuskan pandangan ini dalam istilah “ membangun sugesti positif”. Proses percepatan belajar bisa dicapai apabila kondisi kelas menyenangkan. ${ }^{23}$

Penulis menyimpulkan bahwa permainan dalam belajar mempunyai manfaat diantaranya; menyingkirkan keseriusan yang menghambat prose pembelajaran, menghilangkan stres dalam lingkungan belajar, membangun kreativitas diri, meningkatkan proses

\footnotetext{
${ }^{22}$ Ibid.,hlm. 37.

${ }^{23}$ Ibid.,
}

belajar dan meraih makna belajar melalui pengalaman.

\section{Bentuk-bentuk Permainan Edukatif dalam Pembelajaran Bahasa Arab \\ a. Qirā'ah al huruf al fựdà}

Permainan ini bertujuan melatih peseta didik membaca rangkaian huruf acak kacau siswa dapat membaca katakata dan kalimat sederhana dengan lancar dan tepat. Adapun alat yang diperlukan adalah kertas potongan kecil, lem, papan tulis, dan alat tulis. Cara bermain:

1. Peserta didik dibagi menjadi berpasangan. Sampaikan bahwa mereka akan terlibat dalam permainan menemukan benda yang susunannya huruf acak.

2. Guru memberikan potongan kertas kecil kepada masing-masing peserta didik. Kertas kecil tersebut diberi nomor urut.

3. Masing-masing peserta didik diminta bekerja sama berpasangan menulis nama benda.

4. Setelah tim selesai menulis, guru meminta tiap peserta didik untuk menempel kertas tersebut di papan secara berjajar sesuai dengan urutan angka atau nomornya.

5. Guru meminta peserta didik secara bergiliran maju dan mengambil satu kartu di depan, lalu membacanya dengan nyaring.

6. Jika yang dibaca salah, maka peserta didik harus dihukum.

7. Peserta didik bergiliran mengambil kartu dan membacanya.

\section{b. Tusuk Gramatika}

Tujuan dari permainan ini adalah agar peserta didik dapat mengelompokkan 
jenis kata dan menambah perbendaharaan kata. Permainan ini juga cocok mengajarkan identifikasi dan pengelompokan. Misalnya, identifaksi macam-macam kalimat, membedakan jenis huruf, dan lain sebagainya.

Alat yang diperlukan dalam permainan ini antara lidi dan kertas yang berbetuk kosa kata mufradat, baik berupa kelompok kata, kalimat, huruf, dan lain sebagainya. Cara bermain:

1. Guru membuat lingkaran kecil dari kertas manila

2. Guru membagi peserta didik menjadi beberapa kelompok

3. Guru memberikan instruksi tentang mekanisme tusuk kata kepada masing-masing kelompok. Masingmasing kelompok mencari dan mengurutkan kelompok yang telah diacak dan menyusunnya dengan menusukkan kata sejenis yang sesuai dengan kelompok kata tersebut. Misalnya, tusuk 1 berisi kata sifat, tusuk 2 berupa kata kerja, tusuk 3 adalah kata benda, dan tusuk 4 terdiri atas kata sambung.

4. Peserta didik mencari, mendiskusikan, dan mengklasifikasi kata sesuai dengan bagiannya masingmasing.

5. Setelah permainan selesai, tiap kelompok mengirim perwakilan untuk mepresentasikan hasil diskusinya. $^{24}$

Penilaian bisa dilakukan oleh guru dengan menyebutkan kesalahan atau melihat jumlah kata yang salah tusuk.

24 Fathul Mujib dan Nailur, Metode Permainan-permainan, op. cit., hlm. 87

\section{c. Sahih Khața'}

Tujuan permainan ini melatih peserta didik mendengarkan dan memahami suara tertentu. Alat yang diperlukan tulisan $\mathrm{s}\}$ ah $\left\{\right.$ ih $\{$ dan khat $\} \mathrm{a}^{\prime} \mathrm{di}$ lantai, pertanyaan yang harus dibacakan oleh guru dan peserta didik sebagai pendengarnya. Pertanyaan bisa berupa materi bahasa Arab yang sudah diajarkan oleh guru, baik tentang struktur gramatika atau bacaan lainnya. Cara bermain:

a. Bagi peserta didik menjadi dua tim

b. Peserta didik berdiri dalam dua baris

c. Tulis șahịh atau khata' (dua kategori) di lantai. Tempelkan di sebelah kanan dan kiri peserta didik

d. Jika guru mengatakan sesuatu dengan tepat, maka peserta didik bergerak satu langkah ke kanan. Tapi jika kalimat itu salah, maka mereka harus bergerak ke kiri.

e. Peserta didik yang pindah ke sisi yang salah harus diberi hukuman. ${ }^{25}$

\section{d. Al Kalimātu al Mutaqațị'ah}

Tujuan permainan ini untuk mengembangkan penguasaan peserta didik dalam hal kosa kata dan membaca. Melalui permainan ini, peserta didik berlatih membaca dengan menemukan kata di tengah-tengah huruf acak. Peserta didik menggabungkan huruf-huruf yang telah disusun acak dalam satu tabel (kotak). Selain itu, peserta didik mengenal kosa kata yang sebelumnya sudah diketahui. Cara bermain:

Guru menyiapkan tabel kotak yang telah disusun huruf acak di dalamnya. Kemudian membagi-bagikannya pada

\footnotetext{
${ }^{25}$ Ibid., hlm. 142-143.
} 
setiap peserta didik. Peserta didik melingkari huruf acak, membacanya, lalu menerjemahkannya.

Carilah rangakain huruf yang dapat membentuk kata dengan cara horizontal atau vertikal!

\section{KESIMPULAN}

Sebagai penutup pembahasan tulisan ini, maka dapat diambil beberapa kesimpulan:

1. Permainan bahasa bertujuan memperoleh kesenangan dan melatih

\begin{tabular}{|c|c|c|c|c|c|c|c|c|c|c|}
\hline ي & $ه$ & J & r & ق & ي & ت & أ & J & ق & ت \\
\hline J & 9 & ي & $\tau$ & أ & ك & J & ن & 1 & ظ & J \\
\hline س & $\dot{\varepsilon}$ & $\varphi$ & $ت$ & ي & ت & $\dot{\tau}$ & 1 & J & 1 & ف \\
\hline 1 & $\varepsilon$ & ة & ك & ش & $\varphi$ & ض & ص & د & $J$ & j \\
\hline J & هـ & ت & j & J & أ & $\jmath$ & $\varepsilon$ & $\jmath$ & ج & ي \\
\hline$\ddot{0}$ & ش & ث & ظ & ب & ي & J & $\tau$ & س & 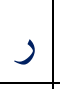 & 9 \\
\hline ت & ج & 1 & ش & ذ & ب & J & ق & ث & ي & ن \\
\hline$J$ & م & $ه$ & 1 & j & ي & r & 1 & 1 & |د د & 1 \\
\hline$J$ & 1 & د & س & ل & T & ف & b & $\varphi$ & ة & j \\
\hline ب & $\varepsilon$ & $\dot{ن}$ & b & ق & ي & $\dot{\tau}$ & 1 & ك & 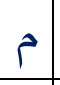 & س \\
\hline ن & ب & ت & ك ك & أ & س & ق & $\dot{ن}$ & ك & & ي \\
\hline
\end{tabular}
keterampilan berbahasa. Jika suatu permainan menimbulkan kesenangan tetapi tidak memperoleh keterampilan berbahasa, maka permainan tersebut bukan termasuk permainan bahasa. Sebaliknya, apabila suatu kegiatan bertujuan melatih keterampilan berbahasa, namun tidak ada unsur kesenangan, maka kegiatan itu bukan termasuk permainan bahasa.

2. Metode permainan edukatif merupakan salah satu aspek yang menentukan keberhasilan belajar peserta didik. Oleh karena itu pendidik harus mampu berkreasi dalam menerapkan metode permainan edukatif yang dapat motivasi peserta didik untuk belajar.

3. Penerapan metode permainan ini

\section{e. Qum Qumi}

Tujuan permainan ini agar peserta didik mampu membedakan kata perintah ('amr) untuk muzakkar dan mu'annats. Cara bermain:

Sebelum permainan dimulai, terlebih dahulu guru menyiapkan beberapa kata perintah yang akan digunakan dalam permainan. Kemudian guru menjelaskan tata cara permainan, misalkan ketika guru menyebutkan kata qum maka yang berdiri adalah peserta didik laki-laki, namun ketika guru menyebutkan kata qumi> maka yang berdiri adalah peserta didik perempuan. membutuhkan persiapan yang matang sebelum diterapkan. Oleh karena itu pendidik harus menyiapkan rencana pelaksanaan pembelajaran sebelum masuk kelas.

\section{DAFTAR PUSTAKA}

Ahmad, Muhammad Abdul Qadir. 1979. Turuq Ta'tim al-Lugah al'Arabiyyah. cet. I; Kairo-Mesir : Maktabah an-Nahḍah al-Mișriyyah.

Arsyad, Azhar. 2010. Bahasa dan Metode Pengajarannya; Beberapa Pokok 
Pikiran Yogyakarta: Pustaka Pelajar.

Departemen Pendidikan Nasional. 2001. Kamus Besar Bahasa Indonesia edisi ketiga. cet. I; Jakarta: Balai Pustakan.

Fadilah, Muhammad dkk. 2013. Pendidikan Karakter Usia Dini: Konsep \& Aplikasinya dalam PAUD. Cet. I; Jogjakarta: Ar-Ruzz Media.

Haddade, Hasyim. 2011. Reformulasi Kurikulum Bahasa Arab . Cet. I; Makassar: Alauddin Press.

Mujib, Fathul dan Nailur Rahmawati. 2011. Metode Permainan Edukatif dalam Belajar Bahasa Arab. Jogjakarta: Diva Press.

Permainan Edukatif Pendukung Pembelajaran Bahasa Arab (2). Jogjakarta: Diva Press.

Nuha, Uli. 2012. Metodologi Super Aktif Pembelajaran Bahasa Arab. Jogjakarta: Diva Press.

Rasyid, Ramli. 2011. "Pengaruh Penggunaan Media Pembelajaran terhadap Prestasi Belajar Siswa pada Mata Pelajaran Bahasa Arab di MAN I Makassar", Tesis.

Syah, Muhibbin. 2006. Psikologi Pendidikan dengan Pendekatan Baru. Bandung: Remaja Rosda Karya.

Tim Penyusun Kamus Bahasa Indonesia. 2008. Kamus Bahasa Indonesia. Jakarta: Pusat Bahasa Departemen Pendidikan Nasional. 


\title{
PENGARUH PENGUASAAN BAHASA ARAB TERHADAP KEMAMPUAN MENGHAFAL AL-QUR'AN MAHASISWI SEMESTER II MA'HAD AL-BIRR MAKASSAR
}

\author{
Nursiah \\ Mahasiswa Prodi Pendidikan Bahasa Arab Fakultas Agama Islam \\ Universitas Muhammadiyah Makassar \\ Nur Fadilah Amin \\ Dosen Prodi Pendidikan Bahasa Arab Fakultas Agama Islam \\ Universitas Muhammadiyah Makassar
}

\begin{abstract}
Language is the means of communication in sharing thoughts, ideas, concepts or feelings used by humans both orally and writing. Every nation has its own language, for example Arabic . Arabic is the language that used by the Arabian society. It has a distinctive as the language that is used in the Qur'an, the holy book of Moslem . Arabic Language then became one of the language that is studied all over the world. There are Some opinions that learning Arabic is one of the most difficult and hard to do, so that some people still not interested to learn it. But Without conscious, by studying Arabic and understanding it well, it will be very helpful in memorizing and mastering the Holy Qur'an. This research was conducted at Ma'had Al-Birr Makassar in Jl.Sultan Alauddin 259 Makassar. This study aims To determine the influence of mastery the Arabic language and the ability to memorize Al-Qur'an of the second semester student on Ma'had Al-Birr Makassar. This research is expected to gives good benefit For Students to improve their motivation in memorizing and mastering Al-Qu'ran, for the lecturers are expected can help to provide learning motivation student in mastery and memorize Al-Qu'ran. Besides, for the researchers are expected to provide benefits to apply and implement Arabic language in memorize Al-Qur'an. The research method used is a quantitative approach such as Interview Guide, questionaires, Observation Guide and files. The data obtained was analyzed by regression analysis and Anova 5\% (percent). The result of this research is the ability of mastery of Arabic language by second semester student on Ma "had Al-Bir in academic year 2015-2016 has a positive effect toward the ability in memorize Al-Qur'an at $5 \%$ (percent) significance level from 4.67 .
\end{abstract}

\section{Keywords: Language, Arabic, Holy Qur'an}

\begin{abstract}
Abstrak
Bahasa merupakan alat komunikasi dalam menyampaikan pikiran, gagasan, konsep atau perasaan yang digunakan oleh manusia baik secara lisan maupun tertulis. Setiap bangsa memiliki bahasa masing-masing, misalnya Bahasa Arab. Bahasa arab adalah bahasa yang digunakan oleh masyarakat bangsa arab. Ia memiliki keistimewaan yaitu bahasa yang digunakan dalam Al-quran, kitab suci umat muslim. Bahasa Arab kemudian menjadi salah satu bahasa yang dipelajari hampir diseluruh penjuru dunia. Beberapa pendapat mempelajari bahasa arab merupakan salah satu hal yang sangat sulit dan sukar, sehingga
\end{abstract}


masih kurang tertarik untuk mempelajarinya. Tetapi tanpa disadari bahwa dengan mempelajari bahasa arab dengan baik serta memahaminya, itu akan sangat membantu dalam menghafal dan menguasai Al-Qur'an. Penelitian ini dilakukan di Ma'had Al-Birr Makassar Jl.Sultan Alauddin 259 Makassar. Penelitian ini bertujuan Untuk mengetahui pengaruh penguasaan bahasa arab dan kemampuan menghafal Al-Qur'an mahasiswi semester II Ma'had Al-Birr Makassar. Sehingga penelitian ini diharapkan dapat memberikan manfaat baik Bagi Mahasiswa yaitu Meningkatkan motivasi dalam menghafal dan menguasai Al-Qu'ran, untuk dosen diharapkan dapat memberikan manfaat dalam membantu memberikan motivasi belajar yang mudah kepada mahasiswa dalam menguasai dan menghafal Al-Qu'ran. Sedangkan untuk peneliti diharapkan dapat memberikan manfaat mengaplikasikan dan mengimplementasikan pengusaan bahasa arab dalam menghafal Al-Qur'an. Adapun metode penelitian yang digunakan adalah pendekatan kuantitatif yaitu Panduan wawancara, Kertas tes, Panduan observasi dan Arsip. data yang telah diperoleh dianalisis dengan analisis regresi dan Anova 5\%. Hasil dari penelitian ini yaitu kemampuan penguasaan bahasa Arab mahasiswi semester II Ma"had Al-Birr tahun pelajran 2015-2016 berpengaruh positif terhadap kemampuan menghafal Al-Qur'an pada taraf signifikansi 5\% yaitu 4,67.

\section{Kata kunci : Bahasa, Bahasa Arab, Al-Qur'an}

\section{PENDAHULUAN}

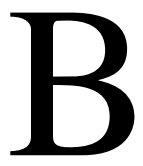

ahasa merupakan salah satu media menyampaikan maksud dan tujuan seseorang yang satu kepada yang lainnya. Menurut Izzan bahasa merupakan sistem lambanglambang (simbol-simbol) berupa bunyi yang digunakan oleh sekelompok orang atau masyarakat tertentu untuk berkomunikasi atau berinteraksi. Dengan bahasa sebuah gagasan atau pikiran bisa tersampaikan dengan jelas. Setiap bangsa memiliki bahasa masingmasing, bahkan satu bangsa bisa memiliki lebih dari satu bahasa. Setiap bahasa juga memiliki keunikan dan keistimewaan tersendiri, seperti Bahasa Arab. Bahasa arab adalah bahasa yang digunakan oleh masyarakat bangsa arab. Ia memiliki keistimewaan yaitu sebagai bahasa yang digunakan dalam Al-quran, kitab suci umat muslim. Sebagaimana dalam firman Allah SWT : "Sesungguhnya Kami menurunkannya berupa Al Quran dengan berbahasa Arab, agar kamu sekalian menjadi orang yang berakal.". (QS : Yusuf : 2)

Dengan keistimewaan yang dimilikinya itu, Bahasa Arab kemudian menjadi salah satu bahasa yang dipelajari oleh banyak orang, tidak hanya di negerinya saja tetapi hampir diseluruh penjuru dunia. Memang kebanyakan orang masih ada yang menganggap bahwa mempelajari bahasa arab itu adalah salah satu hal yang sangat sulit dan sukar, sehingga masih kurang tertarik untuk mempelajarinya.

Tetapi tidak kita sadari bahwa sebenarnya dengan mempelajari bahasa arab dengan baik serta memahaminya, itu akan sangat membantu kita dalam menghafal dan menguasai Al-Qur'an, terutama kandungan-kandungannya. Oleh karena itu, kita sebagai umat muslim 
khususnya, alangkah lebih baiknya jika kita bisa menghafal dan memahami pokok dari kandungan Al-Qur'an yang menjadi pedoman hidup kita sebagai manusia dengan baik dan benar. Adapun salah satu cara menguasai AlQur'an yang mudah itu ialah dengan mempelajari serta menguasai bahasa yang digunakannya terlebih dahulu, yaitu memahami Bahasa Arab.

Dalam proses pembelajaran dengan menggunakan Bahasa Arab sebagai bahasa pengantar di semester II Ma'had Al-Birr Makassar. Di semester II Ma'had Al-Birr Makassar ini juga telah dipelajari berbagai penguasaan dalam pelajaran Bahasa Arab, yaitu nahwu, sharaf, qiraa"ah dan kitaabah. Dengan pengusaan terhadap cabang- cabang pelajaran dalam Bahasa Arab tersebut sudah bisa dikatakan bahwa mahasiswi Ma'had Al-Birr sudah menguasai Bahasa Arab. Dengan begitu peneliti tertarik untuk meneliti apakah benar dengan pengusaan Bahasa Arab tersebut mahasiswi semester II Ma'had Al-Birr Makassar, berpengaruh terhadap kemampuan menghafal Al-Qur'an, yang sebelumnya masih sangat sulit untuk menghafal Al-Qur'an karena kurangnya pengusaan terhadap Bahasa Arab. Peneliti mengambil mahasiswi semester II Ma'had Al-Birr Makassar sebagai subjek penelitian karena di semester ini ayat Al-Qur'an yang dipelajari semakin sulit dan itu membuat para mahasiswi harus betulbetul bisa memahami arti dari apa yang mereka hafal dan apakah salah satunya dengan pengusaan Bahasa Arab yang telah mereka pelajari dapat mempengaruhi kempampuan menghafal Al-Qur'an atau malah sebaliknya.

Berdasarkan uraian latar belakang masalah di atas, maka permasalahan yang dapat dirumuskan dalam penelitian ini adalah sebagai berikut :

1. Adakah pengaruh pengusaan Bahasa Arab terhadap kemampuan menghafal Al-Qur'an mahasiswi semester II Ma'had Al-Birr Makassar?

2. Seberapa besar pengaruh penguasaan Bahasa Arab terhadap kemampuan menghafal Al-Qur'an mahasiswi semester II Ma'had AlBirr Makassar?

Sesuai dengan permasalahan di atas, maka tujuan yang melandasi penelitian ini Untuk mengetahui ada atau tidak pengaruh penguasaan Bahasa Arab terhadap kemampuan menghafal Al-Qur'an mahasiswi semester II Ma'had Al-Birr Makassar. Untuk mengetahui seberapa besar pengaruh pengusaan Bahasa Arab terhadap kemampuan menghafal AlQur'an mahasiswi semester II Ma'had Al-Birr Makassar.

Adapun hasil dari penelitian ini diharapkan dapat memberikan manfaat baik secara langsung maupun tidak langsung antara lain:

- Bagi Mahasiswa : Meningkatkan motivasi siswa serta mempermudah dalam menghafal dan menguasai Al-Qu'ran setelah mempelajari Bahasa Arab. 
- Bagi Dosen: Penelitian ini memberikan manfaat bagi dosen dalam membantu memberikan motivasi belajar yang mudah kepada mahasiswa dalam menguasai dan menghafal AlQu'ran, yaitu dengan mempelajari Bahasa Arab. Bagi Peneliti: Adapun bagi peneliti untuk dapat memberikan manfaat dalam mengaplikasikan dan mengimplementasikan pengusaan bahasa arab dalam menghafal AlQur'an.

\section{METODE PENELITIAN}

Penelitian ini dilakukan di Ma'had Al-Birr Makassar, yang terletak di J1.Sultan Alauddin 259 Makassar. Penelitian ini Insya Allah dilaksanakan dalam jangka waktu 3 bulan.

\section{A. Pendekatan Penelitian}

Pendekatan penelitian yang digunakan yaitu pendekatan kuantitatif, karena yang ingin diketahui adalah pengaruh mempelajari Bahasa Arab terhadap kemampuan menghafal AlQur'an dan seberapa besar pengaruhnya.

\section{B. Subjek Penelitian}

1. Populasi

Populasi dalam penelitian ini atau yang menjadi subjek populasi adalah seluruh mahasiswi semester II Ma'had Al-Birr Makassar, Tahun Ajaran 2015/2016, yang terdiri dari tiga kelas, yaitu kelas pagi, kelas siang I dan kelas siang ب.

2. Sampel Penelitian

Sampel dalam penelitian ini adalah 5 orang perwakilan setiap kelas semester II Ma'had Al-Birr Makassar. Dengan menggunakan teknik Simple Random Sampling yaitu diambil secara acak dari kelompok yang homogen tanpa memperhatikan strata yang ada. Karena dengan 5 orang tersebut diperkirakan bisa mewakili dari populasi yang kemampuan mahasiswinya kurang lebih sama.

\section{Teknik Penelitian}

1. Observasi

Observasi adalah pengamatan dan pencatatan secara sistematik terhadap obyek yang diteliti, baik dalam situasi buatan yang secara khusus diadakan (laboratorium) maupun dalam situasi alamiah atau sebenarnya (lapangan)8. Metode observasi digunakan untuk mengumpulkan data tentang gambaran umum lokasi sekolah yang diteliti dan bagaimana berlangsungnya KBM.

2. Dokumentasi

Dokumentasi digunakan untuk mengumpulkan data tentang gambaran umum Ma'had Al-Birr Universitas Muhammadiyah Makassar yang meliputi letak geografis, sejarah berdirinya Ma'had, keadaan guru, keadaan siswa, serta dokumentasi lain yang mendukung kelengkapan data.

3. Wawancara 
Teknik pengumpulan data ini dilakukan untuk mencari dan mengumpulkan data dari kepala sekolah, guru bidang studi AlQur'an serta dari siswa tentang kemampuan menghafal Al-Qur'an.

4. Tes

Tes sebagai intrumen pengumpul data adalah serangkaian pertanyaan atau latihan yang digunakan untuk mengukur ketrampilan, pengetahuan, intelegensi, kemampuan, atau bakat yang dimiliki oleh individu atau kelompok. Tes digunakan untuk mengetahui bagaimana kemampuan mahasisiwi dalam menghafal Al-Qur'an.

\section{Instrumen Penelitian}

Instrumen penelitian adalah suatu alat yang digunakan untuk mengukur fenomena alam maupun sosial yang diamati. ${ }^{54}$ Instrumen yang digunakan dalam penelitian ini sebagai berikut:

\section{Panduan wawancara}

Kertas tes

Panduan observasi.

Arsip.

\section{E. Teknik Analisis Data}

Analisis data diartikan sebagai upaya mengolah data menjadi informasi, sehingga karakteristik atau sifat-sifat data tersebut dapat dengan mudah dipahami dan bermanfaat untuk menjawab masalah-masalah yang berkaitan dengan kegiatan penelitian10. Adapun teknis analisis

\footnotetext{
54 Sugiyono, metode penelitian penididikan (penekatan kuantitatif, kualitatif dan R\&D). (Bandung:Alfa beta, 2013) hlm. 148
}

data yang berbentuk inferensial dilakukan dengan statistik inferensial, yaitu statistik yang digunakan untuk menganalisis data dengan membuat kesimpulan yang berlaku umum. Hasil dari perhitungan rumus statistik inilah yang menjadi dasar pembuatan generalisasi dari sampel bagi populasi11. Setelah data terkumpul kemudian jawabab-jawaban tes tersebut dianalisa dan data tersebut direkap, maka data tersebut dimasukkan dalam kategori baik, cukup dan kurang, atau tinggi, sedang dan rendah. Untuk itu, pengelolaan data yang bersifat statistik, dalam penelitian ini, penulis melakukan tiga tahapan, yaitu :

1. Analisis Pendahuluan

Pada tahap ini, data yang telah diperoleh selama penelitian berlangsung dimasukkan kedalam tabel-tabel sesuai kebutuhan yang kemudian dimasukkan kedalam distribusi frekuensi untuk setiap variable

\section{Analisis Uji Hipotesis}

Analisis uji hipotesis merupakan perhitungan lanjut dari analisis pendahuluan dengan menggunakan analisis regresi, karena dalam penelitian ini terdiri dari satu kreterium penguasaan Bahasa Arab (X) dan satu prediktor kemampuan menghafal AlQur'an Mahasiswi semester II Ma'had Al-Birr Makassar tahun 2015/2016 (Y). Sedang langkah-langkah analisis regresi adalah sebagai berikut ${ }^{55}$ :

55 Ridwan dan Sunarto, pengantar statistik (Bandung:Alfa Beta, 2009) hlm. 97-102 
a) Membuat Ha dan Ho dalam bentuk kalimat :

Ha : Terdapat pengaruh variabel $\mathrm{X}$ terhadap variabel $\mathrm{Y}$

Ho : Tidak terdapat pengaruh variabel $\mathrm{X}$ terhadap variabel $\mathrm{Y}$

b) Membuat Ha dan Ho dalam bentuk statistik :

Ha : $r \neq 0$ : Terdapat pengaruh variabel $\mathrm{X}$ terhadap variabel $\mathrm{Y}$

Ho $: r=0:$ Tidak terdapat pengaruh variabel $\mathrm{X}$ terhadap variabel $\mathrm{Y}$

c) Membuat tabel penolong untuk menghitung angka statistik

d) Memasukkan angka-angka statistik dari tabel penolong dengan rumus:

- Menghitung rumus b

$$
\mathrm{b}=\frac{n \cdot \sum X Y-\sum X \cdot \sum Y}{n \cdot \sum X^{2}-\left(\sum X\right)^{2}}
$$

- Menghitung rumus a

$$
\mathrm{a}=\frac{\sum Y-b \cdot \sum \mathrm{X}}{n}
$$

- Menghitung persamaan regresi sederhana

$$
\dddot{Y}=a+b X
$$

- Membuat garis persamaan regresi

a. Menghitung rata-rata $\mathrm{X}$ dengan rumus:

$$
\bar{X}=\frac{\sum X}{n}
$$

b. Menghitung rata-rata $\mathrm{Y}$ dengan rumus:

$$
\bar{Y}=\frac{\sum Y}{n}
$$

e) Mencari jumlah kuadrat regresi ( $\mathrm{JK}_{\mathrm{reg}}[\mathrm{a}]$ ) dengan rumus :

$$
\left(J K_{\text {reg }[a]}\right)=\frac{\sum X^{2}}{n}
$$

f) Mencari jumlah kuadrat regresi $\left(J K_{\text {reg }[a \mid b]}\right)$ dengan rumus :

$$
\left(J K_{\text {reg }[a \mid b]}\right)=\text { b. }\left\{\sum \mathrm{XY}-\frac{\sum \mathrm{X} \cdot \sum \mathrm{Y}}{n}\right\}
$$

g) Mencari jumlah kuadrat residu ( $\mathrm{JK}_{\mathrm{Res}}$ ) dengan rumus :

$J K_{R e s}=\sum \mathrm{Y}^{2}-J \mathrm{~K}_{\mathrm{Reg}\langle\mathrm{b} \mid \mathrm{a}\rangle}-\mathrm{JK}_{\mathrm{Reg}[\mathrm{a}]}$

h) Mencari rata-rata jumlah kuadrat regresi $\mathrm{RJK}_{\mathrm{Reg}[\mathrm{a}]}$ dengan rumus:

$$
R J K_{R e g[a]}=J K_{R e g[a]}
$$

i) Mencari rata-rata jumlah kuadrat regresi ${ }_{\text {Reg[alb] dengan rumus: }}$

$$
R J K_{\operatorname{Reg}[a \mid b]}=J K_{\operatorname{Reg}\left[\left.a\right|_{b}\right]}
$$

\begin{tabular}{|c|c|c|c|c|c|}
\hline $\begin{array}{l}\text { Sumber } \\
\text { Variasi }\end{array}$ & Dk & JK & KT & $F_{\text {hitung }}$ & $\underline{F}_{\text {tebal }}$ \\
\hline Total & n & $\sum x^{2}$ & - & \multirow{4}{*}{$\frac{S^{2} \operatorname{Reg}}{S^{2} \operatorname{Res}}$} & \multirow{4}{*}{$\mathrm{F}_{\text {(adbreg alb dhres }}$} \\
\hline Koefisien (a) & 1 & $\mathbb{N}_{(a)}$ & $\mathrm{RJK}_{(\mathrm{a})}$ & & \\
\hline Regresi $a b$ & 1 & $J_{(a b)}$ & $\mathrm{RJK}_{(\mathrm{a} / \mathrm{b})}=\mathrm{S}_{\mathrm{Reg}}^{z_{\text {eq }}}$ & & \\
\hline sisa & $\mathrm{n}-2$ & $J_{\mathrm{Res}}$ & $\mathrm{RJK}_{(a b)}=\mathrm{S}^{2}{ }_{\text {Res }}$ & & \\
\hline
\end{tabular}

j) Mencari rata-rata jumlah kuadrat residu $\mathrm{RJK}_{\mathrm{Res}}$ dengan rumus :

$$
R J K_{\text {Res }}=\frac{J K_{\text {Res }}}{n-2}
$$

k) Menguji signifikasi dengan rumus :

$$
F_{\text {hitung }}=\frac{R J K_{\text {Reg }[a \mid b]}}{R J K_{\text {Res }}}
$$

1) Membuat kesimpulan

Tabel rangkuman Analisis of Varian (ANOVA ) 


\section{Analisa Data}

Dalam analisis lanjut dilakukan analisis data-data hasil penelitian, kemudian membuat interpretasi lebih lanjut sampai pada kesimpulan. Analisis ini membandingkan harga Fhitung yang telah diketahui dengan Ftabel pada taraf signifikansi $5 \%$ atau $1 \%$, dengan kemungkinan :

- Jika Fhitung > Ftabel, maka tolak Ho artinya signifikan

- Jika Fhitung < Ftabel, maka terima Ho artinya tidak signifikan

\section{HASIL}

\section{PENELITIAN DAN}

PEMBAHASAN

\section{A. Selayang Pandang tentang Ma'had Al-Birr Makassar}

\section{Sejarah Singkat}

Kata "Al-Birru" adalah kata dalam bahasa Arab yang biasa diterjemahkan dalam bahasa Indonesia sebagai "kebaikan". Kata al-birr di pakai oleh Allah SWT dalam beberapa ayat dalam Al-Qur'an (misalnya pada surah Al-Baqarah ayat 177). Semoga Ma'had dan Lembaga pendidikan yang menempati areal kampus Unismuh makassar ini menebarkan kebaikan yang banyak dan berkah.

Pada awalnya, Ma'had ini didirikan pada tahun 1996, sebagai hasil kerja sama PP Muhammadiyah dengan Yayasan Dar el-Birr yang berkedudukan di Dubai, Uni Emirat Arab. Setelah lembaga ini resmi berdiri, maka diambillah dari nama yayasan tersebut sebagai nama lembaga. Selengkapnya bernama: Lembaga Pendidikan Islam dan Bahasa Arab Ma'had Al-Birr Unismuh Makassar.

Belakangan, Ma'had Al-Birr kemudian dikelolah oleh AMCF (Asia Muslim Charity Foundation) atau Yayasan Muslim Asia. Baik Yayasan Dar el- birr yang merupakan cikal bakal berdirinya, maupun Yayasan Muslim Asia (AMCF) yang mengelolahnya hingga sekarang; tidak lepas dari kiprah seorang dermawan dari Dubai bernama Dr. Muhammad Thayyib Khoory.hafizhallah.

AMCF yang didirikan oleh Syekh Khoory adalah murni organisasi sosial non-profit dan non-politik. Yayasan ini telah berjalan sejak 1992 dan didirikan secara resmi di Jakarta pada tahun 2002. AMCF telah memiliki surat rekomendasi dari Majelis Ulama Indonesia (MUI), Departemen Kehakiman, Departemen Agama, Departemen Sosial, dan Badan Pertahanan Nasional Republik Indonesia. AMCF aktif dalam kegiatan-kegiatan sosial, dakwah, kesehatan, dan pendidikan serta bidang usaha.

\section{Visi dan Misi}

Visi

Menjadi Ma'had Bahasa Arab yang Terkemuka dan Model dalam memajukan dan memadukan pendidikan bahasa Arab, dakwah, dan pengabdian pada masyarakat.

Misi 
1) Menghasilkan da'i yang mampu dalam bidang bahasa Arab, berakhlak mulia, berkompetensi akademik, dan profesional tinggi serta berkarakter pembelajar sepanjang hidup.

2) Menciptakan lingkungan akademik yang kondusif dan optimal untuk meningkatkan kualitas pendidikan bahasa Arab dan dakwah islamiyah.

3) Menumbuhkan semangat cinta dan menyebarluaskan bahasa Arab, hafal Al-Qur'an, ilmu syar'i dan seni Islam bagi kemaslahatan ummat manusia.

\section{Program Studi dan Masa Pendidikan}

a. At-Tamhidy (Pra Persiapan Bahasa)

Level dimaksudkan sebagai kelas persiapan bagi mahasiswa agar dapat mengikuti perkuliahan pada program Al-I'dad Al-Lughawi yang merupakan awal jenjang perkuliahan yang sebenarnya di Ma'had. Di program ini mahasiswa belajar satu semester penuh.

\section{b. Al-I'dad Al-Lughawi (Persiapan Bahasa)}

Al-I'dad Al-Lughawi dianggap sebagai level awal pembelajaran di Ma'had. Pada level ini mahasiswa belajar selama dua tahun atau empat semester (setara DII).

\section{c. Syu'batu At-Ta'lim At-Takmiily (Program Komplementer)}

Program takmiily adalah jenjang penyempurna program al-i'dad allughawi dan merupakan jenjang terakhir yang dapat ditempuh oleh mahasiswa di Ma'had hingga AMCF dapat membuka program untuk tingkat Universitas. Pada program level ini mahasiswa belajar selama satu tahun (dua semester) penuh (setara DIII).

Sistem pendidikan Ma'had Al-Birr Makassar mengacu pada Al-Qur'an dan As-sunnah. Sedang kurikulum yang dipakai sejalan dengan apa yang diterapkan pada Universitas Islam Madinah dan Universitas Imam Muhammad bin Su'ud Riyadh, Saudi Arabia. Karena itu pola pembelajaran bahasa Arab dan studi Islam yang dianut merujuk kepada Lembaga Ilmu Pengetahuan Islam dan Arab (LIPIA) Jakarta, yang merupakan perguruan tinggi resmi filial dari Universitas Imam Muhammad bin Su'ud Riyadh. Metodologi pengajaran disampaikan secara sistematis, variatif dengan pengantar utama bahasa Arab.

Tenaga pengajar Ma'had Al-Birr Makassar memiliki latar belakang pendidikan Sarjana, Magister dan Doktor yang berkualifikasi di bidangnya serta berasal dari berbagai perguruan tinggi terkemuka di Timur Tengah dan Indonesia.Program pendidikan di Ma'had Al-Birr Makassar ditempuh selama dua tahun (4 semester) atau setara Diploma Dua (D2). Dan sangat terbuka peluang untuk ditingkatkan menjadi 3 tahun (6 semester)/setara Diploma Tiga (D3) atau bahkan Strata Satu (S1) pada masa yang akan datang. Bagi alumni yang ingin melanjutkan ke jenjang pendidikan yang lebih tinggi, dapat melanjutkan ke perguruan-perguruan Tinggi Muhammadiyah se-Indonesia, 
LIPIA Jakarta serta Perguruanperguruan tinggi negeri maupun swasta lainnya. Alumni yang berprestasi dapat diberikan rekomendasi untuk belajar di Timur Tengah.

Di samping sebagai lembaga pendidikan, Ma'had Al-Birr Makassar memiliki program-program sosial, seperti: Pendirian Sarana Ibadah dan Pendidikan, Pengiriman da'i dalam program Safari Ramadhan di berbagai wilayah pada Kawasan Timur Indonesia, Distribusi Hewan Qurban, Program Ifthar Ramadhan, Penyaluran zakat-infak-Shadaqoh (ZIS), serta Pemberian santunan kepada anak-anak yatim, kaum dhuafa dan korban bencana alam.

Selain Ma'had Al-Birr Makassar, AMCF juga mengelola dan membina beberapa Ma'had dan Markaz Tahfizh Al-Qur'an yang tersebar di beberapa propinsi di Indonesia yang bekerjasama dengan Pimpinan Pusat Muhammadiyah melalui Perguruan Tinggi Muhammadiyah (PTM), Persatuan Islam (PERSIS), serta berbagai organisasi kemasyarakatan resmi lainnya di Indonesia.

\section{B. Penguasaan Bahasa Arab terhadap Kemampuan Menghafal Al- Qur'an}

\section{Deskripsi Data Hasil Penelitian}

Untuk memperoleh data tentang penguasaan Bahasa Arab, dapat diperoleh dari nilai raport mahasiswi pada tahun pelajaran 2015/2016. Adapun untuk memperoleh data tentang kemampuan menghafal
Al-Qur'an, dapat diperoleh dari tes kemampuan menghafal Al-Qur'an yang telah diberikan kepada mahasiswi sebagai responden yang berjumlah 15 mahasiswi. Responden diminta untuk menghafalkan Al-Qur'an, dengan memperhatiakn tajwid, dan cara menghafal Al-Qur'an.

Untuk mengetahui jawaban yang lebih jelas mengenai data hasil penelitian dapat dilihat pada deskripsi sebagai berikut :

1. Data tentang penguasaan

Mahasiswi Semester II Ma'had

Al-Birr Makassar (X)

Untuk mengetahui nilai data tentang penguasaan bahasa Arab mahasiswi dapat dilihat dari nilai raport mata pelajaran bahasa Arab yang dicapai mahasiswi semester II Ma'had Al-Birr Makassar tahun pelajaran 2015/2016 sebagaimana dalam Tabel 1.

Setelah dilakukan penghitungan, data pada Tabel 1 kemudian dapat dianalisis sebagai berikut :

a. Menetukan kualifikasi dan interfal nilai, dengan cara menentukan range atau jangkauan : $\mathrm{R}=X_{\text {maks }}-$ $X_{\min }$

$\mathrm{R}=95.5-63=32$

$K=1+3,3 \log n$

$\mathrm{K}=1+3,3 \log 15=1+(3,3 \mathrm{x}$ $1,50)$

$$
=1+4.95=5,95
$$

$\mathrm{K}=6$

Sehingga diketahui interval nilai : 
$\mathrm{I}=\frac{R}{K}=\frac{15}{6}=2,5$ dibulatkan jadi 3

Dengan demikian dapat diperoleh kualifikasi dan interval nilai pada Tabel II.

TABEL II

Interval Nilai (X) dan Nilai Rata-Rata (Mean)

\begin{tabular}{|c|c|c|c|c|c|}
\hline No. & Interval & $\mathrm{F}$ & $\mathrm{X}$ & $\mathrm{Fx}$ & Rata-Rata \\
\hline 1. & $63-65$ & 2 & 64 & 128 & \\
\hline 2. & $66-68$ & 1 & 67 & 67 & \multirow{X}{*}{$\begin{array}{c}\sum f x \\
\sum f\end{array}$} \\
\hline 3. & $69-71$ & 1 & 70 & 70 & \multirow{2}{*}{$=\frac{1242}{15}$} \\
\hline 4. & $72-74$ & 0 & 73 & 0 & \multirow{2}{*}{$=82,8$} \\
\hline 5. & $75-77$ & 0 & 76 & 0 & \\
\hline 6. & $78-80$ & 1 & 79 & 79 & \\
\hline 7. & $81-83$ & 1 & 82 & 82 & \\
\hline 8. & $84-86$ & 0 & 85 & 0 & \\
\hline 9. & $87-89$ & 3 & 88 & 264 & \\
\hline 10. & $90-92$ & 4 & 91 & 364 & \\
\hline 11. & $93-95$ & 2 & 94 & 188 & \\
\hline & & 15 & & 1.242 & \\
\hline
\end{tabular}

b. Distribusi frekuensi relatif penguasaan bahasa arab mahasiswi semester II Ma'had Al-Birr Makassar pada Tabel III.

TABEL III

Distribusi Frekuensi Relatif Penguasaan Bahasa Arab Mahasiswi Semester II Ma'had Al-Birr Makassar

\begin{tabular}{|c|c|c|c|}
\hline Nomor & Interval & $\mathrm{F}$ & Fr (\%) \\
\hline 1. & $63-65$ & 2 & 14 \\
\hline 2. & $66-68$ & 1 & 7 \\
\hline 3. & $69-71$ & 1 & 7 \\
\hline 4. & $72-74$ & 0 & 0 \\
\hline 5. & $75-77$ & 0 & 0 \\
\hline 6. & $78-80$ & 1 & 7 \\
\hline 7. & $81-83$ & $T$ & 7 \\
\hline 8. & $84-86$ & 0 & 0 \\
\hline 9. & $87-89$ & 3 & 21 \\
\hline 10. & $90-92$ & 4 & 28 \\
\hline 11. & $93-95$ & 2 & 14 \\
\hline & & 15 & 100 \\
\hline
\end{tabular}

c. Menentukan kualitas variabel penguasaan bahasa Arab

Untuk menentukan jumlah inteval dalam menyusun kualitas penguasaan bahasa Arab dapat dicari dengan cara sebagai berikut ; nilai tertinggi dikurangi nilai terendah dibagi jumlah interval, yakni : $95-63: 3=10,6$. Hasil jumlah interval disajikan pada Tabel IV.

TABEL IV

Kualitas Variabel Penguasaan Bahasa Arab

\begin{tabular}{|c|c|c|c|}
\hline Rata-Rata & Interval & Kualitas & Kriteria \\
\hline \multirow{3}{*}{82,8} & $85-95$ & Sangat Baik & \multirow{2}{*}{ Baik } \\
\cline { 2 - 3 } & $74-84$ & Baik & \\
\cline { 2 - 3 } & $63-73$ & Cukup & \\
\hline
\end{tabular}

Dari analisis data pada Tabel IV, diketahui bahwa penguasaan bahasa Arab mahasiswi semester II Ma'had Al-Birr Makassar termasuk dalam kategori baik, yaitu berada pada interval nilai 79 86 dengan nilai rata-rata 82,8 .

\section{d. Gambar Hinstogram}

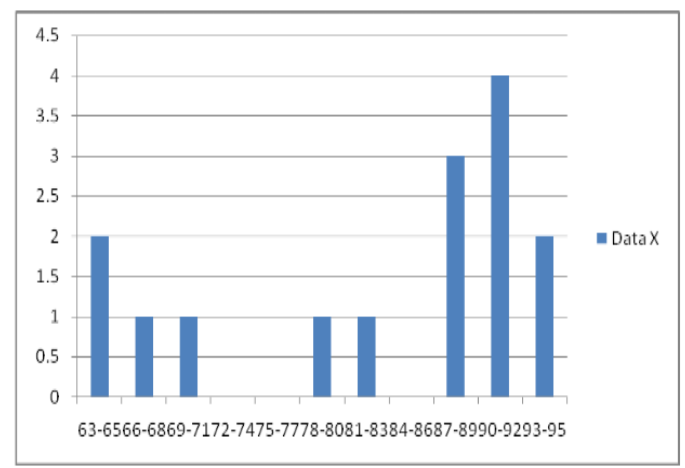

2. Data tentang kemampuan menghafal Al-Qur'an Mahasiswi semester II Ma'had Al-Birr Makassar.

Untuk menentukan nilai kuantitatif kemampuan menghafal Al-Qur'an adalah dengan menjumlahkan skor jawaban soal tes dari responden sesuai dengan frekuensi jawaban Tabel V. 
TABEL V

Hasil Tes Kemampuan Menghafal Al-Qur'an Mahasiswi Semester II Ma'had Al-Birr Makassar

\begin{tabular}{|c|c|c|c|}
\hline \multirow{2}{*}{ No.Responden } & \multicolumn{2}{|c|}{ Nilai } & \multirow{2}{*}{ Nilai } \\
\cline { 2 - 3 } & Hafalan & Tajwid & \\
\hline 1 & 85 & 73 & 79 \\
\hline 2 & 81 & 85 & 83 \\
\hline 3 & 98 & 78 & 88 \\
\hline 4 & 92 & 86 & 89 \\
\hline 5 & 95 & 91 & 93 \\
\hline 6 & 97 & 91 & 94 \\
\hline 7 & 89 & 95 & 92 \\
\hline 8 & 99 & 85 & 92 \\
\hline 9 & 98 & 94 & 96 \\
\hline 10 & 86 & 88 & 87 \\
\hline 11 & 93 & 89 & 91 \\
\hline 12 & 93 & 87 & 90 \\
\hline 13 & 97 & 93 & 95 \\
\hline 14 & 94 & 90 & 92 \\
\hline 15 & 94 & 94 & 94 \\
\hline Sumber data: hasil tes & & \\
\hline
\end{tabular}

Setelah dilakukan penghitungan data pada Tabel $\mathrm{V}$, maka kemudian data dapat dianalisa sebagai berikut :

a. Menetukan kualifikasi dan interval nilai, dengan cara menentukan range atau jangkauan:

$\mathrm{R}=X_{\operatorname{maks}}-X_{\min }$

$\mathrm{R}=96-79=17$

$K=1+3,3 \times \log n$

$\mathrm{K}=1+3,3 \mathrm{x} \log 15=1+(3,3 \mathrm{x}$ $1,50)=1+4.95=5,95$

$\mathrm{K}=6$

Sehingga diketahui interval nilai $: \mathrm{I}=\frac{R}{K}=\frac{17}{6}=2,83$ dibulatkan 3

Dengan demikian dapat diperoleh kualifikasi dan interval nilai seperti pada Tabel VI.
TABEL VI

Interval Nilai (Y) Dan Rata-Rata (Mean)

\begin{tabular}{|c|c|c|c|c|c|}
\hline No & Interval & F & y & Fy & Rata-Rata \\
\hline 1 & $79-81$ & 1 & 80 & 80 & \multirow{2}{*}{$\bar{Y}=\frac{\sum f y}{\sum f}$} \\
\hline 2 & $82-84$ & 1 & 83 & 83 & \\
\hline 3 & $85-87$ & 1 & 86 & 86 & \\
\cline { 1 - 4 } 4 & $88-90$ & 3 & 89 & 267 & 1356 \\
\hline 5 & $91-93$ & 5 & 92 & 460 & \multirow{2}{*}{$=90.4$} \\
\hline 6 & $94-96$ & 4 & 95 & 380 & \\
\hline & & 15 & & 1356 & \\
\hline
\end{tabular}

b. Tabel distribusi frekuensi relative kemampuan menghafal al-qur'an pada Tabel VII

TABEL VII

Distribusi Frekuensi Relatif Kemampuan Menghafal Al-Qur'an

\begin{tabular}{|c|c|c|c|}
\hline Nomor & Interval & Frekuensi (f) & Fr (\%) \\
\hline 1 & $79-81$ & 1 & 7 \\
\hline 2 & $82-84$ & 1 & 7 \\
\hline 3 & $85-87$ & 1 & 7 \\
\hline 4 & $88-90$ & 3 & 21 \\
\hline 5 & $91-93$ & 5 & 35 \\
\hline 6 & $94-96$ & 4 & 28 \\
\hline & & 15 & $100 \%$ \\
\hline
\end{tabular}

c. Menentukan kualitas variabel kemampuan menghafal Al-Qur'an

Untuk menentukan jumlah interval dalam menyusun kualitas kemampuan menghafal Al-Qur'an dapat dicari dengan cara sebagai berikut ; nilai tertinggi dikurangi nilai terendah dibagi jumlah interval, yakni: 96 - $79: 3=5,6$. Hasil jumlah interval disajikan pada Tabel VIII.

Dari analisis data di atas, diketahui bahwa kemampuan menghafal Al- Qur'an mahasiswi semester II Ma'had Al-Birr Makassar termasuk dalam kategori sangat baik, yaitu berada di antara interval nilai $85-90$ dan 91- 96 dengan nilai rata-rata 90,4. 
TABEL VIII

Kualitas Variabel Kemampuan Menghafal Al-Qur'an

\begin{tabular}{|c|c|l|c|}
\hline Rata-Rata & Interval & Kualitas & Kriteria \\
\hline \multirow{3}{*}{90,4} & $91-96$ & Sangat Baik & \multirow{3}{*}{ Sangat Baik } \\
\cline { 2 - 3 } & $85-90$ & Baik & \\
\cline { 2 - 3 } & $79-84$ & Cukup & \\
\hline
\end{tabular}

d. Gambar Hinstogram

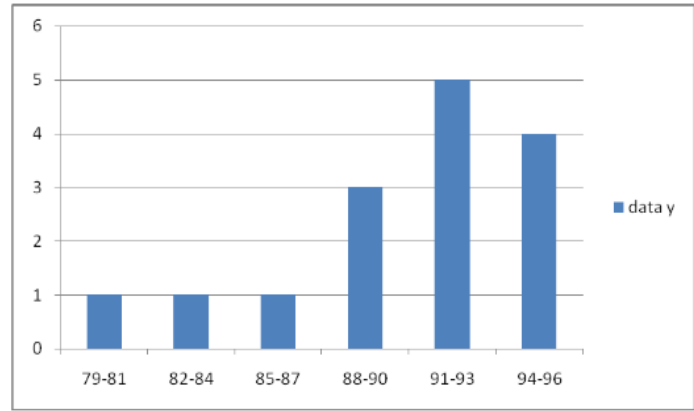

\section{Pengujian Hipotesis}

Hipotesis yang akan diuji kebenarannya adalah untuk menentukan pengaruh antara variabel penguasaan bahasa Arab (X) terhadap kemampuan menghafal Al-Qur'an Mahasiswi Semester II Ma'had AlBirr Makassar 2015-2016 (Y).

Untuk memudahkan dalam penghitungan maka perlu dibuat tabel kerja/bantu sebagaimana telah disajikan pada Tabel IX.

Dari Tabel IX diketahui:

$$
\begin{aligned}
& N=15 \\
& \sum X=1242 \\
& \sum Y=1355 \\
& \sum X^{2}=104700 \\
& \sum Y^{2}=122699
\end{aligned}
$$

$$
\begin{aligned}
& \sum X Y=111910 \\
& \bar{X}=82,8 \\
& \bar{Y}=90,4
\end{aligned}
$$

TABEL IX

Tabel Kerja Regresi Penguasaan Bahasa Arab Terhadap Kemampuan Menghafal Al-Qur'an Mahasiswi Semester II Ma'had Al-Birr Makassar 2015-2016

\begin{tabular}{|c|c|c|c|c|c|}
\hline NO. & $\mathrm{X}$ & $\mathrm{Y}$ & $\mathrm{X}^{2}$ & $\mathrm{Y}^{2}$ & $\mathrm{XY}$ \\
\hline 1. & 91 & 79 & 8281 & 6241 & 7189 \\
\hline 2. & 93 & 83 & 8649 & 6889 & 7719 \\
\hline 3. & 95 & 88 & 9025 & 7744 & 8360 \\
\hline 4. & 92 & 89 & 8464 & 7921 & 8188 \\
\hline 5. & 92 & 93 & 8464 & 8649 & 8556 \\
\hline 6. & 90 & 94 & 8100 & 8836 & 8460 \\
\hline 7. & 89 & 92 & 7921 & 8464 & 8188 \\
\hline 8. & 82 & 92 & 6724 & 8464 & 7544 \\
\hline 9. & 89 & 96 & 7921 & 9216 & 8544 \\
\hline 10. & 87 & 87 & 7569 & 7569 & 7569 \\
\hline 11. & 80 & 91 & 6400 & 8281 & 7280 \\
\hline 12. & 63 & 90 & 3969 & 8100 & 5670 \\
\hline 13. & 69 & 95 & 4761 & 9025 & 6555 \\
\hline 14. & 66 & 92 & 4356 & 8464 & 6072 \\
\hline 15. & 64 & 94 & 4096 & 8836 & 6016 \\
\hline Jml. & $\mathbf{1 2 4 2}$ & $\mathbf{1 3 5 5}$ & $\mathbf{1 0 4 7 0 0}$ & $\mathbf{1 2 2 6 9 9}$ & $\mathbf{1 1 1 9 1 0}$ \\
\hline & & & & & \\
& $\mathbf{8 2 , 8}$ & $\mathbf{9 0 , 4}$ & $\mathbf{6 9 8 0}$ & $\mathbf{8 1 7 9 , 9 4}$ & $\mathbf{7 4 6 0 , 6 6}$ \\
\hline & & & & & \\
\hline
\end{tabular}

Selanjutnya data tersebut diolah kedalam rumus analisis regresi dengan langkah-langkah sebagai berikut :

A. Memasukkan angka-angka statistik dari tabel penolong dengan rumus :

- Menghitung rumus b :

$$
\mathrm{b}=\frac{15.111910-1241.1355}{15.104700-(1242)^{2}}
$$

$$
=\frac{-4260}{27936}=-0,1525
$$

- Menghitung rumus a :

$$
\begin{aligned}
a & =\frac{1355-(-0,1525) \cdot(1242)}{15} \\
& =\frac{190760}{15}=12717,34
\end{aligned}
$$


- Menghitung persamaan regresi sederhana :

$\overline{\mathrm{Y}}=\mathrm{a}+\mathrm{bX} \widehat{\bar{\Psi}} \neq 2717,34+(-$ 0,1525).(X)

- Membuat garis persamaan regresi
a) Menghitung rata-rata $X$ dengan rumus :

$$
\bar{X}=\frac{1242}{15}=82,8
$$

b) Menghitung rata-rata $Y$ dengan rumus :

$$
\bar{Y}=\frac{1355}{15}=90,4
$$

B. Mencari jumlah kuadrat regresi ( $\mathrm{JK}_{\text {reg }[\mathrm{a}]}$ ) dengan rumus :

$$
\begin{aligned}
\left(J K_{\text {reg }[a]}\right) & =\frac{1836025}{15} 122401,7 \\
F_{\text {tebal }} & =F_{\left\{(1-\alpha)\left(d k_{k} r e g\left[\left.a\right|_{b}\right]\right)(d k, r e s)\right\}}
\end{aligned}
$$

C. Mencari

jumlah kuadrat regresi $\left(J K_{\text {reg }[a \mid b]}\right)$ dengan rumus :

$$
=F_{\{(0,95)(1.13)\}}
$$

$$
\begin{aligned}
\left(J K_{\text {reg }[a \mid b]}\right) & =-0,1525(111910 \\
& \left.-\frac{1682910}{15}\right)=160,74
\end{aligned}
$$

D. Mencari jumlah kuadrat residu ( $\mathrm{JK}_{\mathrm{Res}}$ ) dengan rumus :

$$
\begin{array}{lr}
J K_{\text {Res }}= & 122699-43,31 \\
\mathrm{RJK}_{\mathrm{Reg}[\mathrm{a}]} & -122401,7 \\
=254 &
\end{array}
$$

E. Mencari rata-rata jumlah kuadrat regresi dengan rumus:

F.

$$
R J K_{R e g[a]}=J K_{R e g[a]}=122401,7
$$

$$
R J K_{R e g[a \mid b]}=J K_{R e g\left[\left.a\right|_{b]}\right.}
$$

F. Mencari rata-rata jumlah kuadrat regresi $\mathrm{RJK}_{\mathrm{Reg}[\mathrm{a} \mid \mathrm{b}]}$ dengan rumus:

$$
=160,74
$$

G. Mencari rata-rata jumlah kuadrat residu $\mathrm{RJK}_{\mathrm{Res}}$ dengan rumus :

$$
\begin{aligned}
& R J K_{\text {Res }}=\frac{J K_{\text {Res }}}{n-2} \\
& =\frac{254}{13}=19,54
\end{aligned}
$$

H. Menguji signifikasi dengan rumus :

$$
\begin{aligned}
& F_{\text {hitung }}=\frac{R_{\text {Reg }\left[\left.a\right|_{b}\right]}}{R J K_{\text {Res }}} \\
& =\frac{160,74}{19,54}=8,22 \\
& =F_{\left\{(1-0,05)\left(\text { dk.reg }\left[\left.a\right|_{b}\right]=1\right)(\text { dkeres }=15-2=13)\right\}}
\end{aligned}
$$

Dengan taraf signifikansi $(\alpha)=0.05$ dicari nilai Ftabel menggunakan table $\mathrm{F}$ dengan rumus:

$$
\mathrm{F}_{\text {tebal }}=4,67^{3}
$$

Diketahui ;

$$
\begin{aligned}
\mathrm{F}_{\text {hitung }}=8,22 & >F_{\{(0,95)(1.13)\}} \\
& =4,67
\end{aligned}
$$

Dengan demikian, berdasarkan penghitungan diatas, ternyata Fhitung lebih besar dari Ftabel maka Ho ditolak artinya signifikan.Hasil pengujian hipotesis tersebut dapat diringkas dalam tabel anova Sebagai berikut : 


\begin{tabular}{|c|c|c|c|c|c|}
\hline $\begin{array}{l}\text { Sumber } \\
\text { Variasi }\end{array}$ & Dk & JK & KT & $F_{\text {hitung }}$ & $F_{\text {tebal }}$ \\
\hline Total & 15 & 122699 & - & \multirow{4}{*}{8,22} & \multirow{4}{*}{4,67} \\
\hline Koefisien(a) & 1 & 122401,7 & 122401,7 & & \\
\hline Regresi(alb) & 1 & 160,74 & 160,74 & & \\
\hline Sisa & 13 & 254 & 19,54 & & \\
\hline
\end{tabular}

Setelah diketahui hasil penghitungan di atas, untuk mengetahui signifikansi pengaruh penguasaan bahasa Arab terhadap kemampuan menghafal Al-Qur'an Mahasiswi Semester II Ma'had Al-Birr Makassar dengan jalan membandingkan harga Fhitung dengan Ftabel.

Jika Fhitung $>$ Ftabel maka ditolak Ho (signifikan) dan sebaliknya jika Fhitung < Ftabel maka diterima Ho ( tidak signifikan). Dengan taraf signifikansi $5 \%$, dk pembilang 1 dan $\mathrm{dk}$ penyebut $=\mathrm{n}-2=13$, diperoleh Ftabel sebesar 4,67 sedang Fhitung sebesar 8,22, jika dibandingkan keduanya Fhitung $=8,22>$ Ftabel $=$ 4.67 dengan demikian variabel penguasaan bahasa Arab berpengaruh positif dan signifikan terhadap kemampuan menghafal AlQur'an Mahasiswi Semester II Ma'had Al-Birr Makassar.

Fhitung < Ftabel maka diterima Ho ( tidak signifikan). Dengan taraf signifikansi $5 \%$, dk pembilang 1 dan $\mathrm{dk}$ penyebut $=\mathrm{n}-2=13$, diperoleh Ftabel sebesar 4,67 sedang Fhitung sebesar 8,22, jika dibandingkan keduanya Fhitung $=8,22>$ Ftabel $=$ 4.67 dengan demikian variabel penguasaan bahasa Arab berpengaruh positif dan signifikan terhadap kemampuan menghafal AlQur'an Mahasiswi Semester II Ma'had Al-Birr Makassar.

Adapun hasil wawancara dari beberapa mahasiswi semester II tentang pengaruh penguasaan bahasa Arab terhadap kemampuan menghafal Al-Qur'an Mahasiswi pertama dari kelas masaai ', Haslinda Sari mengatakan bahwa :

"Dengan menguasai bahasa Arab bisa membantu kita dalam menghafal Al-Qur"an"(wawancara $26 \mathrm{Mei} 2016)$

Mahasiswi kedua dari kelas shabaahi Nurul Hidayah, mengatakan bahwa :

"Penguasaan bahasa Arab sangat berpengaruh terhadap kemampuan menghafal Al-Qur"an, karena dengan menguasai bahasa Arab, kita bisa lebih mengetahui makna dari ayat-ayat Al-Qur"an".(wawancara 26 Mei 2016).

Mahasiswi ketiga dari kelas masaai I, Ruqayyah mengatakan bahwa :

"Dengan menguasai bahasa Arab maka akan lebih mudah menghafal AlQur"an karena kebiasaan membaca tulisan-tulisan arab".(wawancara 25 mei 2016).

Dari hasil wawancara yang telah peneliti lakukan dari beberapa mahasiswi, peneliti dapat menyumpulkan bahwa penguasaan bahasa Arab sangat berpengaruh terhadap kemampuan menghafal AlQur'an. Karena dengan menguasai bahasa Arab mahasiswi dapat dengan 
mudah mengetahui makna- makna yang terkandung di dalam Al-Qur'an, dan akan mempermudah dalam menghafalkan Al-Qur'an.

\section{KESIMPULAN}

Berdasarkan hasil penelitian yang berjudul "Pengaruh Penguasaan bahasa Arab terhadap kemampuan menghafal Al-Qur"an mahasiswi semester II Ma"had Al-Birr tahun pelajaran 2015-2016" dan sesuai dengan rumusan masalah yang peneliti angkat , maka dapat di ambil kesimpulan sebagai berikut:

1. Ada pengaruh penguasaan bahasa Arab terhadap kemampuan menghafal Al-Qur'an mahasiswi semester II Ma"had Al-Birr tahun pelajran 2015-2016. Hal ini dapat dilihat dari analisis regresi yaitu nilai regresi (Fhitung) diketahui berjumlah 8,22, sedangkan nilai $F_{\text {tebal }}$ untuk $(1 ; 13)=4,67$

2. Pengaruhnya sangat signifikan dengan taraf signifikan 5\%. Ini berarti penguasaan bahasa Arab berpengaruh positif terhadap kemampuan menghafal Al-Qur'an .Keadaan ini menunjukkan bahwa hipotesa yang diajukan adalah signifikan artinya hipotesa tersebut dapat diterima. Atau Ha diterima dan Ho ditolak.

\section{DAFTAR PUSTAKA}

Sugiyono. 2013. Metode Penelitian Pendidikan Kuantitatif Kualitatif dan R\&D,Cet 16: Bandung: Alfabeta.

Faisal hendra,dkk. 2007. Kemampuan Berbahasa Arab. Jakarta: Gaung persada pers. Azhar Arsyad.2003. Bahasa Arab dan Metode Pengajarannya. Yogyakarta:Pustaka Pelajar.

Slameto. Belajar dan Faktor-Faktor yang Mempengaruhinya. Cet IV:Jakarta: PT Rineka Cipta.

Mahmudah Umi,Rosyidi Abdul Wahab. 2008. Active Learning dalam Pembelajaran Bahasa Arab. Malang: UIN Malang Press.

Imam Barnadib. 2002. Filsafat Pendidikan..Yogyakarta:Adicipta Karya Nusa

Ali Muhammad. Guru dalam proses Belajar Mengajar.Bandung : Sinar Baru Algesindo)

Asra Abuzar, Sutomo Slamet. 2014. Pengantar Statistika II.Jakarta: PT.Rajagrafindo Persada.

Kamus Besar Bahasa Indonesia. 1996.

Ridwan dan Sunarto.2009. Pengantar Statistik .Bandung:Alfabeta. hal.97102

http://ahmadmukhlasinalkasuba.blogs pot.co.id/2012/09/problemumum-dalam- belajar-bahasaarab.html 
http://www.referensimakalah.co

m/2012/12/menghapal-

alquran-pengertian- dasar-

hukum-tujuan-dan-hikmah 


\title{
PENERAPAN MEDIA AL-BITHAQAAT AL-SYAKLIYAH DALAM MENINGKATKAN KOSAKATA BAHASA ARAB SISWA KELAS III SDIT AL-FITYAN
}

\author{
Muhammad Ibrahim \\ Dosen Prodi Pendidikan Bahasa Arab Fakultas Agama Islam \\ Universitas Muhammadiyah Makassar
}

\begin{abstract}
Teaching Arabic vocabularies is a teaching which includes all kinds of the substances in teaching Arabic language. That is because learning vocabularies means learning the language itself. So that the vocabularies play an important role in Arabic language.We cannot say that someone has mastered in Arabic language if he does not have enough vocabularies. Language is one of the important communication instruments in human's life. In the chronological order, the functions of language are an instrument to express feelings, a communicating tool, one of the integrating tools, a social adaptation and control. Someone can communicate with language either in expressing the ideas presents in his mind or in accepting the informations from others. So, language is a comminacating instrument which is used by humanbeings to interact eachother. This article aims to explain the mastering of vocabularies by using media of al-bithaqaat al-syakliyah ". The quality of speaking skill that the learners possess depends on the quality and the quantity of the vocabularies the have. And the leaners who have the quality and the quantity of Arabic vocabularies will able to have more acquirement in speaking Arabic.
\end{abstract}

Keywords: Arabic vocabulary, al-bithaqaat al-syakliyah media

\begin{abstract}
Abstrak
Pembelajaran kosakata bahasa Arab merupakan suatu pembelajaran yang memuat semua unsur-unsur yang terkandung dalam pembelajaran bahasa Arab, karena belajar kosakata bahasa Arab berarti sama saja dengan belajar bahasa itu sendiri. Sehingga kosakata bahasa Arab memegang peranan penting dalam bahasa Arab. Seseorang tidak dapat dikatakan menguasai bahasa Arab kalau belum menguasai kosakata bahasa Arab. Bahasa merupakan alat komunikasi yang penting dalam kehidupan manusia. Secara kronologis, fungsi bahasa adalah untuk menyatakan ekspresi diri, alat komunikasi, alat untuk mengadakan integrasi, adaptasi sosial, dan sebagai alat untuk kontrol sosial. Dengan bahasa, seseorang akan melakukan komunikasi, baik ketika ia akan menyampaikan sesuatu yang ada dalam benaknya maupun menerima kabar dari orang lain. Bahasa adalah alat komunikasi yang digunakan manusia untuk berinteraksi dengan sesama. Tulisan ini bermaksud menjelaskan tentang "Peningkatan Penguasaan Kosakata Bahasa Arab Melalui Media"Al-Bithaqaat AlSyakliyah", karena secara konsepsional kualitas keterampilan berbahasa seseorang tergantung pada kualitas dan kuantitas kosakata yang dimiliki. Dan seseorang yang memiliki kualitas dan kuantitas kosakata bahasa Arab akan mempunyai keterampilan lebih dalam berbicara bahasa Arab.
\end{abstract}

Kata Kunci: kosakata bahasa Arab, media al-bithaqaat al-syakliyah 


\section{PENDAHULUAN}

B ahasa Arab merupakan bahasa asing di Indonesia, dan sebagai bahasa agama

Islam

keberadaannya mutlak diperlukan untuk mempelajari serta mendalami berbagai ilmu pengetahuan Islam, maka tidak mengherankan apabila umat Islam menaruh perhatian terhadapnya. Oleh karena itu, bahasa Arab diajarkan di sekolah-sekolah Islam, madrasahmadrasah, dan pesantren-pesantren yang ada di Indonesia.

Pada era globalisasi sekarang ini, semakin dirasakan betapa pentingnya fungsi bahasa sebagai alat komunikasi. Kenyataan sekarang ini, adalah banyak para ahli yang bergerak dalam bidang teori dan praktik bahasa. Mereka menyadari bahwa interaksi dan segala macam kegiatan dalam masyarakat akan lumpuh tanpa bahasa.

Fungsi bahasa selain sebagai alat komunikasi dan penghubung antara manusia, juga masih banyak fungsi yang lainnya. Di antaranya adalah bahasa merupakan pendukung yang mutlak dari pada keseluruhan pengetahuan manusia. Tidak suatu bidang ilmu apapun yang disampaikan dengan efisien, kecuali lewat media bahasa, dalam kebanyakan bidang pembelajaranbahasa sebagai alat penyampaian adalah yang paling penting dan mutlak diperlukan.

Pembelajaran bahasa arab di SD merupakan program yang relatif masih baru sehingga masih membutuhkan banyak pembenahan, kerja keras dan dukungan dari semua pihak terutama dari para guru, karena seorang guru langsung mengolah proses belajar mengajar di kelas. Dengan kata lain, mereka secara langsung akan mempengaruhi membina dan mengembangkan para siswa. Asumsi yang berkembang dikalangan siswa yang beranggapan bahwa bahasa arab merupakan mata pelajaran sulit menjadi tantangan tersendiri bagi para guru. Hal tersebut menuntut untuk senantiasa mengembangkan potensi yang dimliki, baik dari segi kemampuan penguasaan materi ajar maupun kemampuan strategis lainnya seperti penetuan materi ajar atau teknik pembelajaran, pemilihan media dan sarana lainnya, evaluasi serta waktu yang dibutuhkan untuk mencapai tujuan. Hal tersebut harus senantiasa disesuaikan dengan keadaan siswa serta lingkungan yang dihadapinya. Dengan demikian akan menumbuhkan minat dan keinginan siswa untuk belajar dan menyenangi pelajaran bahasa arab.

Optimalisasi proses belajarmengajar dapat dicapai dengan berbagai cara, salah satunya adalah pemanfaatan media, mulai dari media sederhana sampai pada media yang kompleks (rumit). Pemanfaatan media yang diintegrasikan mutu pelajaran sangatlah berguna, karena media berfungsi sebagai alat bantu untuk menyampaikan pesan. Kegiatan belajar-mengajar yang mengembangkan kesesuaian antara materi pelajaran dan media yang digunakan dapat merangsang minat siswa dan menimbulkan kesiapan siswa untuk terlibat dalam proses belajarmengajar. 
Media pembelajaran sangatlah dibutuhkan dalam penerapan program pembelajaran bahasa arab di SD. Dengan memperhatikan kondisi fisik dan perkembangan kognitif siswa yang masih sangat memerlukan stimulus yang konkrit untuk memahami pesan dalam hal ini materi pelajaran. Namun, yang menjadi permasalahan saat ini adalah keterbatasan media yang sangat dibutuhkan oleh para guru, khususnya dalam pembelajaran bahasa arab di SD. Berdasarkan kenyataan tersebut, peneliti mencoba mengembangkan satu media pembelajaran yang diberi nama "Albithaqatusy al-syakliyah".

Salah satu media yang termasuk media sederhana dalam pembelajaran bahasa arab adalah "Al-bithaqatusy alsyakliyah" yang terbuat dari potonganpotongan karton yang dapat digunakan dalam hubungannya dengan pembelajaran kosakata.

Adapun tujuan yang ingin dicapai adalah:

a. Untuk mengetahui apakah media 'al-bithaqatusy al-asykliyah' dapat meransang minat siswa SD dalam belajar bahasa arab

b. Untuk mengetahui jenis kosakata yang dapat diajarkan melalui media 'al-bithaqatusy al-asykliyah'

\section{METODE PENELITIAN}

Penelitian ini dilakukan selama dua bulan yaitu mulai bulan Januari sampai bulan Februari tahun 2017, dan bertempat di SDIT Al-Fityan Gowa Makassar. Penelitian ini dilakukan dalam dua tahap yaitu: a. Tahap pertama; penyusunan instrumen yang berupa objektif tes dan diadakan uji validitas tes

b. Tahap kedua; uji coba media 'albithaqatusy al-asykliyah' yang dilakukan pada lokasi penelitian

Adapun metode penelitian ini yaitu:

A. Identifikasi Variabel

Beradasarkan judul penelitian, makan yang menjadi variabel dalam poenelitian ini adalah:

1. Variabel bebas (independen) adalah penggunaan media "Albithaqatusy al-Syakliyah"dan penjelasan verbal.

2. Variabel terikat (dependen) adalah pembelajaran kosakata (vocabulary)

\section{B. Desain penelitian}

Desain penelitian yang digunakan adalh desain yang menggunakan pretes dan postes kepada kedua kelompok eksperimen dan kelompok kontrol. Kelompok eksperimen mendapat perlakuan (dengan menggunakan 'albithaqatusy al-asykliyah) sedangkan kelompok kontrol hanya diberikan penjelasan verbal.

Desain penelitian tersebut dapat digambarkan sebagai berikut:

$$
\begin{array}{llll}
\text { E } & \text { O1 } & \text { X } & \text { O2 } \\
\text { K } & \text { O1 } & & \text { O2 }
\end{array}
$$

Keterangan :

E : kelompok eksperimen

$\mathrm{K}$ : kelompok kontrol

O1 :pretes yang dibverikan kepada kelompokeksperimen dan kelompok kontrol 
O2 : pstes yang diberikan kepada kelompok eksperimen dan kelompok kontrol

$\mathrm{X}$ : perlakuan atau treatmen

C. Defenisi Operasional Variabel

Untuk memeproleh persepsi yang sama tentang permasalhan yang dikaji dalam penelitian, maka perlu dikemukakan batasan atau defenisis operasional sebagai berikut:

1. Penggunaan media 'al-bithaqatusy al-asykliyah'

Penggunaan media albithaqatusy al-asykliyah adalah pemnfaatan al-bithaqatusy alasykliyah pada pembelajaran bahasa arab khususnya vocabulary untuk anak usia SD. Media al-bithaqatusy al-asykliyah berupa potongan-potongan karton dengan berbagai macam bentuk seperti lingkaran, persegi empat panjang, bujur sangkar, segitiga dan semacamnya yang dirangkaikan satu sama lain sehingga membentuk atau dapat menyerupai hewan atau bentuk lainnya yang mengandung unsur permainan.

2. Penjelasan verbal

Penjelasan verbal adalah metode tradisional yang digunakan oleh guru dengan memberikan penjelasan teoritis secara verbal

3. Pembelajaran vocabulary

Dalam hal ini pembelajaran vocabulary yang dimaksud adalah kegiatan pembelajaran kosakata khususnya kosakata yang terbentuk dari hasil rangkaian 'albithaqatusy al-asykliyah' teersebut. Kemudian kosakata tersebut dibuat dalam kalimat sederhana sesuai dengan pola yang telah ditentukan.

\section{Populasi dan Sampel}

Populasi dalam penelitian ini adalah murid kelas V SDIT Al-Fityan Gowa. Jumlah murid kelas V SDIT AlFityan Gowa sebanyak 188 orang yang terbagi dalam lima kelas yaitu 3 kelas terdiri dari 46 murid dan 2 kelas terdiri dari 46 murid. Dari keseluruhan jumlah murid kelas V SDIT Al-Fityan Gowa, jumlah sampel dalam penelitian ini sebanyak 40 orang. Sampel ini dibagi dalam 2 kelompok 20 orang untuk kelompok eksperimen dan 20 orang untuk kelompok kontrol. Pengambilan sampel ini dilakukan secara acak atau sampling random dari 46 murid. Kelompok eksperimen adalah kelompok yang diberikan media al-bithaqatusy alasykliyah dalam pembelajaran sedangkan kelompok kontrol tidak diberi perlakuan (al-bithaqatusy alasykliyah).

\section{Teknik Pengumpulan Data}

Pada penelitian ini data dikumpulkan dengan menggunakan objektif tes dan teknik observasi langsung melalui pembelajaran. Prosedur pengumpulan data dapat digambarkan sebagai berikut:

1. Langkah pertama; kedua kelompok diberikan pretes sebanyak 20 nomor selama 30 menit.

2. Langkah kedua yang dilakukan dalam penelitian ini adalah proses pembelajaran kosakata baik untuk 
kelas eksperimen maupun untuk kelas kontrol. Kegiatan ini dilakukan selama satu bulkan, dengan perlakuan kelas eksperimen diajar dengan menggunakan al-bithaqatusy al-asykliyah sebanyak empat kali pertemuan. Setiap pertemuan siswa dibagi dalam empat kelompok yang terdiri atas lima orang siswa. Pada pertemuan pertama dan kedua setiap kelompok diberikan buku penuntun, sedangkan pada dua pertemuan terakhir tidak diberikan buku penuntun. Untuk kelas kontrol, pembelajaran kosakata dilakukan dengan cara memberikan penjelasan verbal tanpa menggunakan media. Namun, materi yang diajarkan direlevankan dengan materi yang diajarkan dikelas eksperimen. Proses pembelajaran di kelas kontrol juga dilakukan sebanyak empat kali pertemuan.

3. Langkah ketiga; kedua kelompok diberikan postes dengan menggunakan soal yang sama pada pretes selama 30 menit.

\section{Instrumen}

Instrumen yang digunakan dalam pengumpulan data pada penelitian ini adalah

1. Tes; yang berupa objektif tes

2. Observasi yang dilakukan secara langsung pada saat pembelajaran

\section{Teknik Analisis Data}

Untuk mengetahui data dalam penelitian ini digunakan statistik inferensial dengan teknik t.tes. teknik digunakan karena merupakan karena merupakan suatu uji coba statistik yang memungkinkan untuk membandingkan
2 kelompok yang independen, maka rumus t-tes yang digunakan adalah:

$$
t=\frac{X 1=X 2}{\sqrt{\left[\frac{S S 1+S S 2}{n 1+n 2-2}\right]\left[\frac{S S 1+S S 2}{n 1+n 2-2}\right]}}
$$

Keterangan :

$$
\begin{aligned}
\mathrm{t} & =\text { Rumus Tes } \\
1 & =\text { Skor kelompok satu } \\
2 & =\text { Skor kelompok dua } \\
\text { SS1 } & \text { Jumlah Kuadrat kelompok }
\end{aligned}
$$$$
\text { Satu }
$$

SS2 = Jumlah Kuadrat kelompok dua $\mathrm{X}^{2}=$ Jumlah dari seluruh jumlah

kuadrat kelompok satu

$\left(\sum \mathrm{X}\right)^{2}=$ Jumlah Kuadrat dari jumlah skor kelompok satu

$\left(\sum \mathrm{X} 2\right)^{2}=$ Jumlah Kuadrat dari jumlah

skor kelompok dua

$$
\begin{array}{cccc}
\mathrm{N} 1 & \text { Jumlah } & \text { Total } & \text { Peserta } \\
\text { Kelompok Satu } & & \\
\mathrm{N} 2 \begin{array}{l}
\text { K Jumlah } \\
\text { Kelompok Dua }
\end{array} & \text { Total } & \text { Peserta } \\
& &
\end{array}
$$

\section{HASIL PENELITIAN DAN PEMBAHASAN \\ 1. Pentingnya Media dan Teknologi Pembelajaran}

Kalau dilihat perkembangannya, pada mulanya media hanya dianggap sebagai alat bantu mengajar guru (teaching aids). Alat bantu yang dipakai adalah alat bantu visual, yaitu gambar, objek dan alat-alat lain yang dapat memberikan pengalaman konkrit, motivasi belajar serta mempertinggi daya serap dan retensi belajar peserta didik. Namun sayang, karena terlalu memusatkan perhatian pada alat bentu visual yang dipakainya orang kurang memperhatikan aspek desain, 
pengembangan pembelajaran produksi dan evaluasinya.

Dengan masuknya pengaruh teknologi audio pada pertengahan abad ke-20 alat visual untuk mengkonkritkan ajaran ini dilengkapi dengan digunakannya alat audio sehingga dikenal adanya alat audio visual atau audio visual aids (AVA). ${ }^{56}$

Hamalik mengemukakan bahwa pemakaian media pembelajaran dalam proses pembelajaran dapat membangkitkan keinginan dan minat yang baru, membangkitkan motivasi dan rangsangan kegiatan belajar, dan bahwa membawa pengaruh-pengaruh psikologis terhadap peserta didik. Penggunaan media pembelajaran pada orientasi pembelajaran akan sangat membantu keaktifan proses pembelajaran dan menyampaian pesan dan isi pelajaran pada saat itu. Selain membangkitkan motivasi dan minat peserta didik, media pembelajaran juga dapat membantu peserta didik mengingkatkan pemahaman, menyajikan data dengan menarik dan terpercaya, memudahkan penafsiran data, dan memadatkan informasi. ${ }^{57}$

Media pembelajaran dapat mempertinggi proses belajar peserta didik dalam pembelajaran yang pada gilirannya diharapkan dapat mempertinggi hasil belajar yang dicapainya. Ada beberapa alasan,

\footnotetext{
${ }^{56}$ Arief S. Sadiman, et al., eds., Media Pendidikan (Pengertian, Pengembangan dan Pemanfaatannya) (Cet. 5; Jakarta: PT RajaGrafindo Persada, 2002), hlm. 6-7.

${ }^{57}$ Azhar Arsyad, Media Pembelajaran, hlm. 1516.
}

mengapa media pembelajaran dapat mempertinggi proses belajar peserta didik. $^{58}$ Alasan pertama berkenaan dengan manfaat media pembelajaran dalam proses belajar peserta didik antara lain:

1. Pembelajaran akan lebih menarik perhatian peserta didik sehingga dapat menumbuhkan motivasi belajar;

2. Bahan pembelajaran akan lebih jelas maknanya sehingga dapat lebih dipahami oleh para peserta didik, dan memungkinkan peserta didik menguasai tujuan pembelajaran lebih baik;

3. Metode mengajara akan lebih bervariasi, tidak semata-mata komunokasi verbal melalui penuturan kata-kata oleh guru, sihingga peserta didik tidak bosan dan guru tidak kehadapatn tenaga, apalagi bila guru mengajar untuk setiap jam pelajaran;

4. Peserta didik lebih banyak melakukan kegiatan belajar, sebab tidak hanya mendengarkan uraian guru, tetapi juga akvitas lain seperti mengamati, melakukan mendemonstrasikan dan lain-lain.

Contoh sederhana, pendidik akan mengajarkan masalah kepadatan penduduk sebuah kota. Ia menggunakan berbagai media pembelajaran antara lain gambar atau foto suatu kota yang padat penduduknya dengan segala permasalahannya. Gambar dan atau foto tersebut akan lebih menarik bagi peserta didik dibandingkan dengan cerita

\footnotetext{
${ }^{58}$ Nana Sudjana dan Ahmad Rivai, Media Pembelajaran, hlm. 2.
} 
pendidik tentang grafik pertumbuhan jumlah penduduk kota tersebut dari tahun ke tahun, sehingga jelas betapa cepatnya pertumbuhan penduduk kota tersebut.

Grafik tersebut dapat memperjelas pemahaman peserta didik terhadap pertumbuhan penduduk dari tahun ke tahun. Para peserta didik dapat melakukan analisis data penduduk, sebab-sebab pertumbuhan penduduk, melakukan proyeksi jumlah penduduk tahun berikutnya, dan aspek lain dari grafik tersebut. Ia juga dapat membuat grafik pendiuduk dan membuat intrepretasinya. Ini berarti kegiatan belajar peserta didik lebih banyak dan lebih mendalam.

Sementara itu pendidik lebih mudah mengatur dan memberi petunjuk kepada peserta didik apa yang harus dilakukannya dari media yang digunakannya, sehingga tugasnya tidak semata-mata menuturkan bahan melalui kata-kata. Penggunaan gambar dan foto serta grafik dalam contoh di atas adalah salah satu cara pembelajaran dengan media pembelajaran.

Alasan kedua mengapa penggunaan media dapat mempertinggi proses dan hasil pembelajaran adalah berkenaan dengan taraf berpikir peserta didik. Taraf berfikir manusia mengikuti taraf perkembangan dimulai dari berfikir kongkret menuju ke berfikir abstrak, dimulai dari berfikir sederhana menuju ke berfikir kompleks. Penggunaan media pembelajaran erat kaitannya dengan tahapan berfikir tersebut sebab melalui media pembelajaran hal-hal yang abstrak dapat dikongkritkan, dan hal-hal yang kompleks dapat disederhanakan.

Sebagai contoh penggunaan peta atau globe dalam pelajaran Ilmu Bumi, pada dasarnya merupakan penyederhanaan dan pengkongkretan dari konsep geografis, sehingga dapat dipelajari peserta didik dalam wujud yang jelas dan nyata. Demikian pula penggunaan diagram yang melukiskan hubungan dan alur-alur terjadinya bel listrik atau bunyi radio merupakam gambaran dan penyederhanaan konsep berfikir abstrak dalam wujud yang mudah dipelajari oleh peserta didik.

\section{Pengembangan Kosakata Bahasa Arab}

Penguasaan suatu bahasa sebenarnya tumbuh dan berkembang melalui tahap-tahap yang nampak jelas pada setiap individu. Masing-masing siswa mempunyai tingkat penguasaan yang berbeda-beda, maka dari itu guru hendaknya selalu memahami tingkat penguasaan siswa terhadap Kosakata Bahasa Arab dengan upaya pengembangan Kosakata Bahasa Arab.

Menurut H.G. Tarigan (1989) dengan mengutip dari buku "Techniques Of Teaching Vocabulary" oleh Prof. Edgar Dale dan kawan-kawannya Yoseph O'Rourke dan Henry A.Bamman (1971 : 51), bahwa dalam upaya pengembangan kata, diperlukan 17 kategori teknik pengembangan kata. Disini penulis hanya mengemukakan 10 teknik pengembangan kosakata, yaitu:

1. Ujian sebagai pembelajaran

2. Petunjuk konteks

3. Sinonim, Antonim dan Homonim 
4. Asal-usul kata

5. Akar kata

6. Ucapan dan Ejaan

7. Semantik

8. Majas

9. Sastra dan Pengembangan kosakata

10. Penggunaan kamus ${ }^{59}$

Untuk lebih jelasnya dapat dilihat pada uraian berikut ini:

1) Ujian sebagai pembelajaran

Pada dasarnya ada 4 cara untuk menguji kosakata, yaitu dengan:

1. Identifikasi yaitu siswa memberi responsi secara lisan ataupun tertulis dengan mengidentifikasi sebuah kata sesuai dengan batasan atau penggunaannya.

2. Pilihan berganda yaitu siswa memilih makna yang tepat bagi kata yang teruji dari tiga atau empat batasan, misalnya.
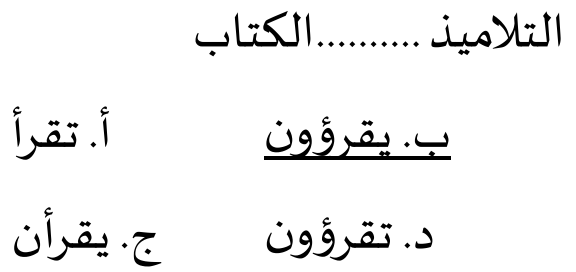

1. Menjodohkan yaitu kata-kata yang teruji disajikan dalam satu lajur dan batasan-batasan yang akan dijodohkan, disajikan secara sembarangan pada lajur lain, misalnya:

a) Rumah بيت

59 Tarigan, HLM. G. 1986. Pengajaran Kosakata. Bandung: Angkasa, hlm. 23
b) Payung

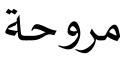
c) Kipas angin

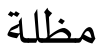

2) Petunjuk konteks

Dalam pembelajarankosakata, teknik penggunaan petunjuk konteks ini terasa amat bermanfaat. Dengan menggunakan petunjukpetunjuk konteks, maka pembaca kerapkali dapat menduga, mengirangira, membayangkan makna suatu kata asing atau kata baru tanpa membuka kamus. Dalam petunjuk konteks ini banyak cara yang bisa diambil sebagai teknik khusus untuk mengajar kosakata, diantaranya adalah dengan "mengajarkan penggunaan petunjuk konteks" yang dipergunakan dengan makna-makna akar kata atau afiks. Dalam hal ini siswa dapat mengembangkan "kata dasar" yang terdapat dalam kurung menjadi kata yang lebih tepat dan sesuai dengan konteks kalimat. Contohnya:

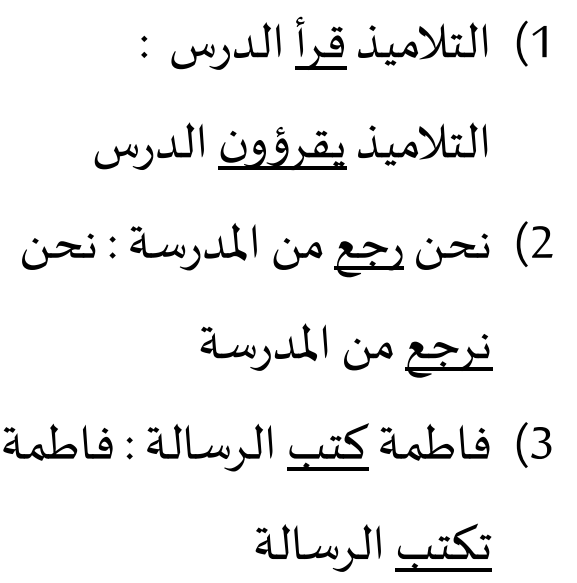

3) Sinonim, antonim dan homonim 
1. Sinonim

Menelaah sinonim merupakan suatu pendekatan yang sangat baik dan juga menghemat waktu bagi telaah

kosakata.

Memperbandingkan sinonimsinonim membantu siswa melihat hubungan antara kata-kata yang bersamaan makna. Selain itu juga menolong para siswa menggeneralisasikan serta mengklasifikasikan kata-kata dan konsep-konsep. ${ }^{60}$

Demikian juga dengan telaah sinonim Kosakata Bahasa Arab bahasa Arab, semakin banyak Kosakata Bahasa Arab yang dimiliki siswa semakin mahir pula ia dalam berbahasa Arab.

Contoh:

- Rumah : بيت - منزل - دار

- Singa : أسس - ليث - نمر

2. Antonim

Cara efektif lain untuk meningkatkan keterampilan kosakata siswa adalah dengan melalui telaah antonim. Antonim diartikan sebagai lawan kata, seperti:

- Besar-kecil

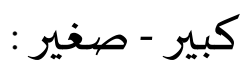

- Panas-dingin ار - مارد

- Jauh-dekat : بعيد - مريب

- Siang-malam :

Dalam menyampaikan pembelajaran antonim ini, suatu

60 Ibid., hlm. 79 kata baru hendaknya diajarkan serentak atau secara bersamaan dengan lawan katanya, seperi kata harus diajarkan serentak dengan (نساء), (غني) dengan (فقير) dan seterusnya yang merupakan lawan kata.

\section{Homonim}

Pengetahuan mengenai homonim dapat memperkaya serta mengembangkan kosakata para siswa dan juga pengetahuan mengenai praktek penggunaan kamus. Homonim diartikan kata yang sama lafal dan tulisannya, tetapi berbeda maknanya karena berasal dari sumber yang berlainan. ${ }^{61}$ Contoh homonim bahasa Arab:

Baik, cantik $^{62}$

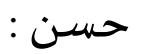

\section{Al-Bithaqatusy Al-Syakliyah}

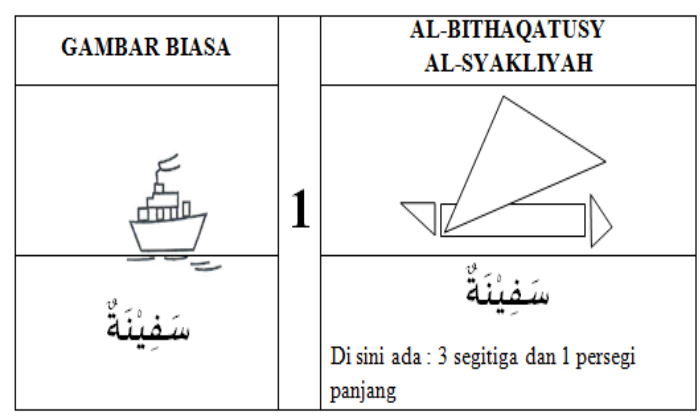

61 Tim Penyusun Kamus Pusat Pembinaan dan Pengembangan Bahasa, Kamus Besar Bahasa Indonesia, (Jakarta: Balai Pustaka, 1996), hlm. 357

${ }^{62}$ A.Warson Munawir, Kamus AlMunawwir Arab-Indonesia, (Yogyakarta: PP. Al -Munawwir Krapyak, 1984), hlm. 310 


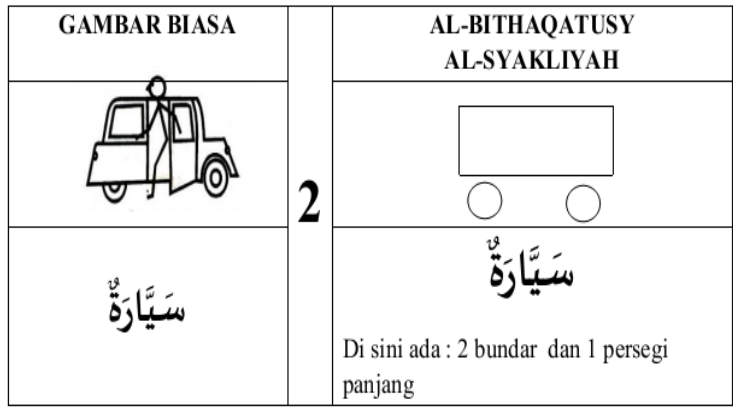

Gambaran singkat tentang

Al-Bithaqatusy Al-Syakliyah. ${ }^{63}$

\section{a) Penyajian Hasil Analisis Data}

Pada bagian ini akan diuraikan hasil penelitian yang diperoleh eksperimen. Berdasarkan hasil tersebut, maka data dapat diolah dengan menggunakan analisis statistik inferensial dengan teknik t-test, yang dimaksudkan untuk menguji kebenaran hipotesis alternatif dan hipotesisi nol.

Hipotesis alternatif yang diajukan dalam penelitian ini adalah ada perbedaan hasil belajar antara siswa yang diberikan treatmen dengan menggunakan media al-bithaqatusy alasykliyah dalam mengajarkan kosakata dengan siswa yang diajar kosakata tanpa menggunakan media albithaqatusy al-asykliyah. Maka hipotesis nolnya adalah tidak ada pebedaan hasil belajar anatara siswa yang diajarkan kosakata dengan menggunakan media al-bithaqatusy alasykliyah dengan siswa yang diajar kosakata tanpa menggunakan albithaqatusy al-asykliyah.

Data yang telah diperoleh, kemudian disusun dan dianalisis,

63 Perlu pembaca ketahui pada tulisan singkat ini kami hanya memperlihatkan dua saja. Sebenarnya masih banyak yang lainnya. kemudian digunakan untuk menganalisis diterima tidaknya hipotesis yang diajukan. Adapun pembahasan dalam penelitian ini, disajikan sebagai berikut:

Keadaaan kedua kelompok diberikan perlakuan, dapat dilihat pada lampiran analisis data dengan rata-rata untuk kelompok eksperimen yaitu 6,950 sedangkan untuk kelompok kontrol yaitu 6,925 .

Untuk menjawab pertanyaan penelitian, yaitu yang mnakah lebih tinggi hasil belajar yang dicapai antara kelompok eksperimen dan kelompok kontrol, maka kelompok eksperimen diberikan trearmen berupa penggunaan media "al-bithaqatusy al-asykliyah dalam belajar kosa kata setelah masingmasing kelompok dibveri pretes yang sama.

Setelah kelompok eksperimen diberi treatmen, maka kelompok eksperimen dan kelompok kontrol diberi posttes yang sama untuk melihat kecenderungan perbedaan dan membandingkan hasil belajar yang dicapai oleh masing-masing kelompok. Dari hasil pengujian tersebut diperoleh nilai rata-rata 9,075 untuk kelompok eksperimen, dan 8,325 untuk kelompok kontrol.

Dengan memperhatikan nilai ratarata yang diperoleh oleh masing-masing kelompok, ternyata dapat dibuktikan bahwa ada perbedaaan hasil belajar yang dicapai oleh siswa yang diajarkan kosakata dengan menggunakan media 'al-bithaqatusy al-asykliyah dengan siswa yang diajarkan hanya melalui 
penjelasan verbal. Namun, perbedaaan tersebut belum tentu signifikan. Untuk membuktikan signifikan tidaknya perbedaan yang terjadi antara kelompok eksperimen dan kelompok kontrol, maka perbedaan tersebut diuji dengan menggunkan statistik inferensial yaitu uji t. Dari hasil analisis sebagaimana yang tercantum pada lampiran, terdapat perbedaan antara nilai median pada kelompok eksperimen dan kelompok kontrol. Dimana perbedaaan tersebut lebih besar dari tingkat probabilitas yang diharapkan $(\mathrm{p}=0,031)$. Dengan demikian, dapat disimpulkan bahwa terdapat perbedaaan yang signifikan antara kelompok kontrol dan kelompok eksperimen.

Dengan demikian, Hi yang menyatakan "ada perbedaaan anatara hasil tes antara kelompok yang diberikan treatmen (kelompok eksperimen dengan kelompok yang tidak mendapatkan treatmen (kelompok kontrol), diterima. Konsekwensinya Ho yang menyatakan tidak ada perbedaan hasil tes antara kelompok eksperimen yaitu kelompok yang diberikan treatmen dengan kelompok kontrol yaitu kelompok yang yang tidak diberi perlakuan", ditolak.

Hasil pengujian tersebut dapat memberikan kesimpulan bahwa ada perbedaaan yang siginfikan antara nilai yang diperoleh dari hasil tes antara kelompok siswa yang tidak diberikan treatmen.

\section{b) Pembahasan Hasil Penelitian}

Kedua kelompok penelitian yang berasal dari latar belakang yang sama, hal ini terbukti dari hasil analisis tentang homogenitas sampel yang dilihat dari distribusi kedua kelompok yaitu kelompok eksperimen dan kelompok kontrol. Sehingga dari dasar itu, pada akhir penelitian terlihat adanya perbedaan hasil tes yang diberikan antara kelompok eksperimen dan kelompok kontrol.

Hasil penelitian membuktikan bahwa treatmen yang diberikan yaitu penggunaan 'Al-bithaqatusy alasykliyah' dalam pembelajaran koskata bahasa Arab dapat membantu meningkatkan minat siswa SD dalam mempelajari bahasa Arab.

\section{KESIMPULAN DAN SARAN}

\section{1) Kesimpulan}

Berdasarkan hasil penelitian dapat disimpulkan bahwa ada perbedaan yang signifikan antara siswa yang diberikan treatmen yang berupa penggunaan 'Albithaqatusy al-asykliyah' dalam pembelajaran kosakata bahasa Arab di SD dengan siswa yang hanya diajar dengan penjelasan verbal.

Dengan demikian penggunaan 'Albithaqatusy al-asykliyah' dalam pembelajaran kosakata bahasa Arab di SD memberikan pengaruh dalam menumbuhkan minat siswa untuk belajar dan menyukai mata pelajaran bahasa Arab sejak dini.

\section{2) Saran-saran}

Berdasarkan hasil pembahasan dan kesimpulan, maka dapat disarankan halhal sebagai berikut:

a. Disarankan kepada para tenaga edukasi, khususnya yang mengajarkan bahasa arab di SD 
agar menggunakan media "Albithaqatusy al-asykliyah" dalam proses belajar mengajar di samping memberikan penjelasan verbal.

b. Diharapkan kepada semua pihak terkait, yaitu departemen pendidikan nasional dan praktisi pendidikan untuk senantiasa memperhatikan kondisi pembelajaran bahasa Arab di SD yang masih memerlukan pembenahan di segala sektor yang terkait di dalamnya terutama sarana dan prasarana yang dibutuhkan untuk mempermudah berlangsungnya proses belajar mengajar.

\section{DAFTAR PUSTAKA}

Al-Qur'anul karim.

A.Warson Munawir. 1984. Kamus AlMunawwir Arab-Indonesia. Yogyakarta: PP.Al -Munawwir, Krapyak.

Arsyad, Azhar. 2010. Media Pembelajaran. Jakarta: PT RajaGrafindo Persada.

Dahlan, J. 1992. Metode Belajar Mengajar Bahasa Arab. Surabaya: Al-Ikhlas.

Banawi, Imam. 1987. Tata Bahasa Arab. Surabaya: Al-Ikhlas

Donoghue Midred, R. 1971. The Child and The English Languange Arts. California. WM.C. Brown Company.
E. Sadtono. 1987. Antologi Pembelajaran Bahasa Asing. Jakarta: Departemen Pendidikan dan Kebudayaan.

Gay, L.R. 1981. Educational.Reserch. USA: Bell dan Howell Company

Munarti. 1996. Pengaruh penggunaan media kartu kata dalam membuat kalimat pada murid SDN 38 pangkajenne Kabupaten Pangkep. Skripsi. Ujung pandang. IKIP Ujung Pandang.

Modi, Nurhaedah. Dkk. 2001. "Shape Cards" Sebagai Media Pembelajaran Bahasa Inggris (Kosakata) Di Sekolah Dasar. Departemen Pendidikan Nasional.

Sadiman, Arief S. Dkk. 2010. Media Pendidikan (Pengertian, Pengembangan dan Pemanfaatannya). Cet. 5; Jakarta: PT RajaGrafindo Persada.

Sudjana, Nana dan Ahmad Rivai. 2010. Media Pembelajaran. Bandung: Sinar Baru Algensindo.

Tarigan, H. G. 1986. Pembelajaran Kosakata. Bandung: Angkasa.

Tarigan, H. G. 1986. Berbicara Sebagai Keterampilan Berbahasa. Bandung: Angkasa

Team, Penyusun. 1975. Pedoman PembelajaranBahasa Arab Pada Perguruan Tinggi Agama (IAIN). Jakarta: Depag RI 
Tim Penyusun Kamus Pusat Pembinaan dan Pengembangan Bahasa. 1996. Kamus Besar Bahasa Indonesia. Jakarta: Balai Pustaka

Sadiman, Arief, Dkk. 1984. Media Pendidikan. Jakarta. PT. Intan Pariwara.

Soepomo. 1987. Media Pembelajaran Bahasa. Jakarta. PT. Intan Pariwara.

Yudhono, Ratih. Media Pembelajaran, http://mynameisobos.blogspot. com/2013/10/makalah-mediapembelajaran.html (23 Oktober 2013). (20 Maret 2015). 


\title{
ANALISIS KEMAMPUAN PENGUCAPAN KOSA KATA BAHASA ARAB SISWA KELAS VIII MADRASAH TSANAWIYAH GUPPI RANNALOE GOWA
}

\author{
Kasmawati \\ Mahasiswa Prodi Pendidikan Bahasa Arab Fakultas Agama Islam \\ Universitas Muhammadiyah Makassar \\ Mahlani \\ Dosen Prodi Pendidikan Bahasa Arab Fakultas Agama Islam \\ Universitas Muhammadiyah Makassar
}

\begin{abstract}
Arabic Language is one of foreign languages which the spreads has been found in several regions and countries. There is no doubt that Arabic language is absolutely necessary in learning and to go deep into the Knowledge about Islam. This is due to the fact that the books which become the source of Islam religion especially the broader and more complete in general still written in Arabic. The difficulties encountered in learning Arabic are influenced by the lack of knowledge of Arabic in the society. This study aims to find out the ability in pronunciation of Arabic vocabulary at the second grade students in Madrasah Tsanawiyah Guppi Rannaloe Gowa and the obstacles which faced by students in the pronunciation of Arabic vocabulary. This research was conducted at Madrasah Tsanawiyah Guppi Rannaloe Gowa, in particular on second grade class. The method used is qualitative. The methods are used in collecting data by researchers in this study, that is: a) Guidelines for observation, direct observation made with phenomenal systematics are investigated by observing the object of study, b) Interview Guidelines, Relate to data is collected on human attitudes and desires, this technique is well suited for obtaining accurate data. c) oral tests, to see how far Arabic vocabulary is pronounced in answering questions verbally and The results of this study shows that the pronunciation ability in Arabic vocabulary by the second grade students in Madrasah Tsanawiyah Guppi Rannaloe Gowa is still below the average due to the lack of knowledge of Arabic language among the students themselves, this is because most of them come from the Primary school which did not know about Arabic language and do study about that.
\end{abstract}

\section{Keywords: Language, Arabic Language, Vocabulary}

\begin{abstract}
Abstrak
Bahasa Arab merupakan salah satu bahasa Asing yang penyebarannya sudah banyak ditemukan di beberapa daerah dan negara.. Sudah tidak diragukan lagi bahwa bahasa Arab mutlak diperlukan dalam mempelajari dan mendalami ilmu pengetahuan Islam. Hal ini disebabkan buku-buku yang menjadi sumber agama Islam terutama yang lebih luas dan lengkap pada umumnya masih ditulis dalam bahasa Arab. Kesulitan yang dihadapi dalam mempelajari bahasa Arab dipengaruhi oleh minimnya pengetahuan bahasa Arab di kalangan masyarakat. Penelitian ini bertujuan untuk mengetahui bagaimana kemampuan pengucapan kosakata bahasa Arab pada sisiwa kelas VIII Madrasah Tsanawiyah Guppi
\end{abstract}


Rannaloe Gowa serta apa saja yang menjadi kendala yang dihadapi siswa dalam pengucapan kosakata bahasa Arab. Penelitian ini dilakukan di Madrasah Tsanawiyah Guppi Rannaloe Gowa,khususnya kelas VIII. Adapun metode yang digunakan bersifat kualitatif. Adapun metode pengumpulan data yang peneliti lakukan dalam penelitian ini, yaitu : a) Pedoman observasi, pengamatan langsung yang dilakukan dengan sistematika fenomenal yang diselediki dengan cara mengamati objek yang diteliti. b) Pedoman wawancara, Berhubungan dengan data yang dikumpulkan menyangkut sikap dan keinginan manusia, maka teknik ini cocok sekali untuk memperoleh data yang akurat. c) tes lisan, untuk melihat seberapa jauh kemampuan pengucapan kosakata bahasa Arab dalam menjawab pertanyaan yang diberikan secara lisan dan. Adapun hasil penelitian ini yaitu Kemampuan pengucapan Bahasa Arab siswa kelas VIII Madrasah Tsanawiyah Guppi Rannaloe Gowa masih di bawah rata-rata dikarenakan minimnya pengetahuan bahasa Arab di kalangan siswa itu sendiri., hal ini disebabkan oleh karena kebanyakan dari mereka berasal dari SD yang belum mengenal bahasa Arab sama sekali dan belum pernah mempelajarinya.

\section{Kata kunci : Bahasa, Bahasa Arab, Kosa kata}

\section{PENDAHULUAN}

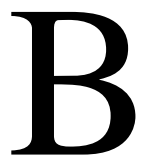
ahasa adalah alat komunikasi diantara manusia dalam menyampaikan maksudnya (Imam Asy Syibahaweih, hal: 8). suatu kaum akan menyampaikan maksud atau tujuan mereka kepada kaum yang lain dengan melalui bahasa. Maka dilihat dari kedudukannya, bahasa adalah sesuatu yang harus dipelajari dan dipraktekan dalam berinteraksi dengan orang lain.

Belajar Bahasa Arab (asing) berbeda dengan belajar bahasa ibu, oleh karena itu prinsip dasar pengajarannya harus berbeda, baik menyangkut metode (model pengajaran), materi maupun proses pelaksanaan pengajarannya. Bidang keterampilan pada penguasaan Bahasa Arab meliputi kemampuan menyimak (listening competence/ mahārah al Istima'), kemampuan berbicara (speaking competence/ mahārah al- takallum), kemampuan membaca (reading competence/ mahārah alqira'ah), dan kemampuan menulis (writing competence/ mahārah alkitābah).

Setiap anak manusia pada dasarnya mempunyai kemampuan untuk menguasai setiap bahasa, walaupun dalam kadar dan dorongan yang berbeda. Adapun diantara perbedaanperbedaan tersebut adalah tujuantujuan pengajaran yang ingin dicapai, kemampuan dasar yang dimiliki, motivasi yang ada di dalam diri dan minat serta ketekunannya mempelajari bahasa asing akan lebih sulit difahami daripada bahasa Ibu (Bahasa Sendiri) karena selain kosa kata yang jarang digunakan, struktur kata dan kalimatpun memerlukan waktu khusus untuk dipelajari. Oleh sebab itu, pengajaran Bahasa Asing dalam lembaga formal dan informal memerlukan metode pengajaran yang 
tepat sesuai dengan tujuan umum pengajaran bahasa itu sendiri.

Bahasa Arab merupakan salah satu bahasa Asing (Luar bahasa pribumi) yang penyebarannya sudah banyak ditemukan di beberapa daerah dan negara. Proses penyebaran bahasa Arab diberbagai Negara adalah pengaruh dari perkembangan Agama Islam yang mana sumber ajaran Agama Islam (al Quran dan As Sunah) menggunakan bahasa Arab.

Sudah tidak diragukan lagi bahwa bahasa Arab mutlak diperlukan dalam mempelajari dan mendalami ilmu pengetahuan Islam. Hal ini disebabkan buku-buku yang menjadi sumber agama Islam terutama yang lebih luas dan lengkap pada umumnya masih ditulis dalam bahasa Arab. Kitab suci umat Islam Al-Qur'an AlKarim dan Hadis Nabawi keduanya ditulis dalam bahasa Arab. Begitu juga dengan kitab-kitab yang ditulis oleh para ulama Islam tentang berbagai cabang ilmu pengetahuan agama Islam masih banyak yang ditulis dalam bahasa Arab.

Untuk itu, tidak mengherankan apabila umat Islam di Indonesia mencurahkan perhatian yang besar pada bahasa Arab. Hal tersebut didasarkan pada kenyataan bahwa bahasa Arab adalah bahasa agama dan bahasa persatuan umat Islam penjuru dunia.

Di Indonesia bahasa Arab dipelajari di sekolah-sekolah agama Islam sejak di tingkat dasar atau Ibtidaiyah sampai ke Perguruan Tinggi,
Pada Madrasah Tsanawiyah Guppi Rannaloe Gowa khususnya. Tujuan khususnya pengajaran bahasa Arab di Madrasah Tsanawiyah Guppi Rannaloe Gowa adalah agar para siswa mampu memahami bahasa, baik melalui pendengaran maupun tulisan (resptif) dan mampu mengutarakan pikiran dan perasaannya, baik secara lisan maupun secara tulisan. Dan tujuan umumnya adalah untuk memahami bahasa AlQuran sebagai bahasa wahyu ilahi dan memahami bahasa komunikasi kedua di dunia setelah bahasa inggris.

Penguasaan bahasa dalam pengucapan kosakata atau muhadatsah di Madrasah Tsanawiyah Guppi Rannaloe Gowa khususnya bahasa Arab, merupakan masalah pokok atau sentral yang harus ditangani secara intensif agar siswa mampu mempelajari literatur-literatur yang diwajibkan serta buku-buku ilmu pengetahuan lainnya. Bahasa Arab yang seharusnya telah dapat digunakan oleh siswa ternyata masih merupakan kesulitan utama yang harus mereka atasi.

Kesulitan yang dihadapi oleh siswa dalam mempelajari bahasa Arab dipengaruhi oleh minimnya pengetahuan bahasa Arab di kalangan siswa itu sendiri, hal ini disebabkan oleh karena kebanyakan dari mereka berasal dari SD yang belum mengenal bahasa Arab sama sekali dan belum pernah mempelajarinya. Di samping itu, ada juga yang berasal Madrasah Ibtidaiyyah, namun tidak semua dari mereka mampu mengucapkan kosakata 
(mufradat) bahasa Arab secara baik dan benar.

Penelitian ini bertujuan untuk mengetahui bagaimana kemampuan pengucapan kosakata bahasa Arab pada sisiwa kelas VIII Madrasah Tsanawiyah Guppi Rannaloe Gowa serta apa saja yang menjadi kendala yang dihadapi siswa dalam pengucapan kosakata bahasa Arab.

\section{Rumusan Masalah}

Berdasarkan latar belakang masalah di atas, penelitian ini dapat dirumuskan sebagai berikut :

1. Bagaimanakah kemampuan pengucapan kosa kata bahasa Arab siswa kelas VIII Madrasah Tsanawiyah Guppi Rannaloe Gowa?

2. Bagaimana upaya yang dilakukan oleh guru dalam membantu siswa pada pengucapan kosa kata bahasa Arab siswa kelas VIII Madrasah Tsanawiyah Guppi Rannaloe Gowa?

\section{METODE PENELITIAN}

Lokasi penelitian dilakukan di Madrasah Tsanawiyah Guppi Rannaloe Gowa,khususnya kelas VIII. Jenis penelitian ini adalah kualitatif, namun untuk mendapatkan data yang maksimal dan optimal atau tercakupnya data, peneliti juga melakukan penelitian perpustakaan (Library research) untuk melengkapi data-data yang didapatkan di lapangan.

Populasi dalam penelitian ini adalah siswa kelas VIII Madrasah Tsanawiyah Guppi Rannaloe Gowa. berdasarkan data yang diperoleh dari laporan rekapitulasi registrasi dan heregistrasi siswa semester ganjil tahun akademik 2015, jumlah siswa kelas VIII Madrasah Tsanawiyah Guppi Rannaloe Gowa berjumlah 28 Orang.

Pengambilan sampel penelitian dilakukan dengan metode Random Sampling, yaitu memilih- milih individu dari kelompok tersebut (Kerlinger, 1995 : 192). Dari jumlah subjek tersebut tidak semuanya dijadikan sebagai subjek penelitian, tetapi penulis menetapkan $30 \%$ dari jumlah subjek. Sehingga subjek penelitian berjumlah 8 orang.

Untuk memperoleh data yang otentik, peneliti menggunakan bentuk dan metode yang sesuai dengan bentuk dan jenis data yang diperlukan. Adapun metode pengumpulan data yang peneliti lakukan dalam penelitian ini, yaitu :

1. Pedoman observasi

Observasi yaitu pengamatan langsung yang dilakukan dengan sistematika fenomenal yang diselediki dengan cara mengamati objek yang diteliti.

2. Pedoman wawancara

Berhubungan dengan data yang dikumpulkan menyangkut sikap dan keinginan manusia, maka teknik ini cocok sekali untuk memperoleh data yang akurat.

3. Tes Lisan

Instrumen tes lisan dalam penelitian ini adalah untuk melihat seberapa jauh kemampuan pengucapan kosakata bahasa Arab pada siswa kelas VIII Madrasah Tsanawiyah Guppi Rannaloe Gowa dalam 
menjawab pertanyaan yang diberikan secara lisan dan sekaligus untuk memperoleh data tentang kemampuan pengucapan kosakata bahasa Arab.

Adapun tehnik pengumpulan data merupakan langkah yang paling strategis dalam penelitian, karena tujuan utama dari peneliian adalah mendapatkan data. Tehnik pengumpulan data yang dilakukan dalam penelitian ini adalah melalui observasi, wawancara dan tes lisan.

Model analisis data yang dipergunakan dalam penelitian ini adalah model analisa analisa data mengalir, yang berarti bahwa peneliti harus melakukan analisa sepanjang penelitian dilakukan, selama peneliti melakukan penelitian terhadap masalah yang diteliti, selama itulah peneliti tetap melakukan analisa data.

Pada tahap pertama, data yang diperoleh dari observasi, wawancara, dan tes lisan serta literatur diedit dengan tujuan untuk meneliti ketepatan, kelengkapan dan kebenaran data. Kemudian, data tersebut disusun berdasarkan kategorisasi yang sesuai dengan masalah dan kebutuhan penelitian. Selanjutnya dibuat kesimpulan sementara. Pada tahap berikutnya dilakukan analisa data dengan tujuan memperoleh berbagai kesimpulan.

Pada tahap kesimpulan awal dan kesimpulan akhir analisa data disesuaikan dengan jenis data yang diperoleh dan jenis masalah yang akan dikaji. Kesimpulan-kesimpulan yang ada perlu diverivikasi lebih lanjut, dari analisa data terakhir inilah ditarik kesimpulan atas hasil penelitian yang dilakukan dilapangan.

\section{KERANGKA TEORI}

\section{A. Kemampuan Berbahasa}

Salah satu aspek penting dalam perilaku adalah kemampuan berkomunikasi dengan orang lain. Apabila seseorang berpikir tentang komunikasi secara umum, maka aspek komunikasi yang pertama kali muncul adalah bahasa. Lebih lanjut, Mustaqim menyatakan bahwa bahasa merupakan alat komunikasi yang akurat bagi kehidupan manusia, sebagai alat komunikasi bahasa digunakan untuk mengkomunikasikan berbagai hal baik yang dirasakan, dipikirkan, dialami maupun yang diangankan oleh individu. Agar berbagai hal yang dikomunikasikan itu dapat diterima secara tepat oleh orang lain, maka bahasa yang digunakan haruslah tepat, jelas dan tidak menimbulkan makna ganda, untuk itu pemakai bahasa selalu dituntut menguasai kaidah-kaidah pemakaian bahasa yang harus mampu menggunakan bahasa itu dalam praktek pemakaian.

Menurut Bloom Lahey (dalam small, 1990 : 26), menyatakan bahwa kemampuan berbahasa dapat dilihat dari tiga dimensi, yaitu dimensi semantik, dimensi sintaksis dan dimensi pragmatika. Dimensi semantik menggambarkan pengetahuan tentang objek atau peristiwa serta hubungan antara objek dan peristiwa tersebut. Dimensi sintaksis berkaitan tentang penyusunan unit-unit bahasa untuk mencari kesesuaian suara dan 
maknanya. Dimensi pragmatika menunjuk pada kemampuan menggunakan bahasa.

\section{B. Bahasa Arab}

Bahasa Arab adalah salah satu bahasa Semit, yaitu bahasa yang dipakai oleh berbagai bangsa keturunan Sam putra Nabi Nuh, kemudian bahasa ini dipakai oleh bangsa Arab kuno yang menempati kepulauan dan sebelah Barat Daya Asia. Bahasa Arab ini kemudian berkembang pesat pada masa awal Islam ketika Al-Qur'an dan Hadis Nabi diturunkan dalam Bahasa Arab yang fasih.

Belajar Bahasa Arab (asing) berbeda dengan belajar bahasa ibu, oleh karena itu prinsip dasar pengajarannya harus berbeda, baik menyangkut metode (model pengajaran), materi maupun proses pelaksanaan pengajarannya. Bidang keterampilan pada penguasaan Bahasa Arab meliputi kemampuan menyimak (listening competence/ mahārah al - Istima'), kemampuan berbicara (speaking competence/ mahārah al-takallum), kemampuan membaca (reading competence/ mahārah al-qira'ah), dan kemampuan menulis (writing competence/ mahārah al kitābah).

Kajian mengenai Bahasa Arab pasti akan selalu dihubungkan dengan kajian agama dan Al-Qur'an. Ini karena dalam kenyataannya Al-Qur'an diturunkan oleh Allah dalam Bahasa Arab. Istilah bahasa Arab seringkali dipergunakan sebagai bahasa AlQur'an, ini memberikan dasar penilaian bahwa Bahasa Arab adalah bahasa agama, orang yang berbicara tentang Islam tentu berbicara tentang Al-Qur'an dan Al-Qur'an itu berbahasa Arab.

Akan tetapi ada beberapa hal yang menunjukkan pentingnya Bahasa Arab di luar motif agama, yaitu :

1. Bahasa Arab kaya akan kosakata dan struktur bahasa, sehingga cocok untuk mengekspresikan pikiran dan emosi serta sebagai alat untuk mengajarkan bermacammacam ilmu pengetahuan.

2. Bahasa Arab mempunyai kepustakaan besar di semua bidang ilmu pengetahuan, orang sangat mengatakan bahwa filsafat dan matematika Yunani sampai ke Barat melalui terjemahan dan tafsiran orang-orang Arab.

3. Bahasa Arab adalah bahasa di mana semua ilmu pengetahuan modern dan kesustraan modern dapat dikemukakan baik dalam bahasa asli maupun dalam bahasa terjemahan.

4. Bahasa Arab adalah bahasa dari kelompok terbesar dunia ketiga, untuk mempersatukan dunia ketiga, bahasa ini patut diperhatikan di Indonesia.

5. Bahasa Indonesia mempunyai banyak kata yang diserap dari Bahasa Arab, jadi Bahasa Arab juga diperlukan dalam studi Bahasa Indonesia.

\section{C. pengertian Upaya Guru}

Pengertian upaya guru adalah usaha yang harus dilakukan oleh guru agarsiswa itu menjadi pribadi yang disiplin. Sebelum mengetahui tentang 
upaya guru dalam menumbuhkan kedisiplinan siswa. Guru harus mengetahiu pribadi siswa, dimana siswa sebagai peserta didik merupakan salah satu input yang ikut menentukan keberhasilan proses pendidikan. Boleh dikatakan hampir semua kegiatan di sekolah pada akhirnya ditujukan untuk membantu siswa mengembangkan potensi dirinya.

Boleh dikatakan hamper semua kegiatan di sekolah pada akhirnya ditujukan untuk mengembangkan potensi dirinya. Upaya itu akan optimal jika siswa sendiri secara aktif berupaya mengembangkan diri sesuai programprogram yang dikembangkan sekolah Oleh karena itu, sangat penting untuk menciptakan kondisi agar siswa dapat mengembangkan diri secara optimal.

Berkenaan dengan manajemen kesiswaan, ada beberapa prinsip dasar yang harus mendapat perhatian berikut ini:

Siswa harus diperlakukan sebagai objek, sehingga harus didorong untuk berperan serta dalam setiap perencanaan dan pengambilan keputusan yang terkait dengan kegiatan mereka.

Keadaan dan kondisi siswa sangat beragam, ditinjau dari kondisi fisik, kemampuan intelektual, sosial ekonomi, minat, dan sebagainya. Oleh karena itu, diperlukan wahana kegiatan yang beragam sehingga setiap siswa memiliki wahana untuk berkembang secara optimal.

Pada dasarnya siswa hanya akan termotivasi belajar, jika mereka menyenangi apa yang diajarkan.
Pengembangan potensi síwa tidak hanya menyangkut ranah kognitif, tetapi juga ranah afektif dan psikomotorik.

\section{HASIL DAN PEMBAHASAN Sejarah berdirinya Madrasah Tsanawiyah Guppi Rannaloe Kecamatan Bungaya Kabupaten Gowa}

Untuk mengetahui secara jelas mengenai sejarah berdirinya atau tinjauan historisnya mengenai Madrasah Tsanawiyah Guppi Rannaloe serta bagaimana tinjauan masyarakat dan pemerintah setempat terhadap berdirinya yayasan atau lembaga ini pada awalnya dapat dikemukakan halhal sebagai berikut:

Madrasah Tsanawiyah Guppi Rannaloe Gowa merupakan salah satu unit dari "yayasan Rannaloe" pemerintahan Kabupaten Gowa sebagai manifestasi dan rasa tanggungjawab akan kewajiban untuk mencerdaskan kehidupan bangsa pada umumnya dan kelanjutan pembangunan Islam pada khususnya.

Salah satu misi dari yayasan “ Madrasah Tsanawiyah Rannaloe Gowa" adalah lebih menekankan pada sumber daya manusia (SDM) dibidang pendidikan, dakwah, pembinaan dan pembudayaan umat Islam dalam hal aqidah dan akhlaq karimah dengan upaya pembinaan dan pemberdayaan kualitas kemampuan Islam dan keterampilan melalui pembinaan dan pelatihan.

Madrasah Tsanawiyah Rannaloe Gowa ini telah terdaftar pada 
Kementerian Agama Republik Indonesia dan mengikuti Kurikulum Tingkat Tsanawiyah. Sehubungan dengan hal tersebut di atas $\mathrm{H}$. Syahruddin, S.Ag menjelaskan sebagai berikut:

Ide timbulnya keberadaan Madrasah Tsanawiyah Guppi Rannaloe Gowa dilatar belakangi oleh situasi dan kondisi masyarakat setempat yang menganggap bahwa betapa pentingnya arti pendidikan pada tingkat Tsanawiyah untuk tiap tahunnya semakin berkembang dan bertambah jumlahnya.

Dengan melihat kondisi yang demikian sehingga para tokoh pendidikan, tokoh masyarakat dan pemerintah yang terkait merasa terbebani perlunya pengadaan Sekolah Agama di daerah tersebut, maka MTs GUPPI Rannaloe resmi didirikan pada tanggal 15 Juli 1996. Dengan Surat Keputusan Nomor 12 diberikan oleh Departemen Agama Provinsi Sulawesi Selatan. MTs GUPPI Rannaloe bertujuan untuk meningkatkan kualitas umat yaitu masyarakat yang bertaqwa kepada Allah SWT, beraqidah Islamiyah, berakhlaq karimah, berilmu pengetahuan, terampil, serta sehat jasmani maupun rohani. Untuk memantapkan usaha yang lebih menjamin terjadinya keterpaduan dari seluruh komponen didalam masyarakat untuk bersama-sama secara gotong royong didalam membina dan mengelolah MTs GUPPI Rannaloe. Dengan demikian MTs GUPPI Rannaloe telah menetapkan suatu struktur organisasi pengurus yang disebut badan pembinaan. Oleh karena itu, dengan adanya MTs GUPPI Rannaloe disambut baik oleh masyarakat setempat dan realisasi dari sambutan tersebut nampak keinginan untuk melibatkan diri dari menyekolahkan anaknya sekaligus masyarakat terlibat dalam pengembangan dan pengurus lembaga pendidikan ini.

\section{Keadaan Guru Dan Siswa}

a) Keadaan guru

Guru merupakan ujung tombak keberhasilan sebuah lembaga pendidikan, guru sebagai pendidik kedua setelah keluarga yang diberikan tanggungjawab moral untuk mendidik dan membimbing sekaligus memberikan pengetahuan kepada siswa. Demikian pula guru yang ada di MTs GUPPI Rannaloe dengan melihat guru yang ada di MTs tersebut kemungkinan akan terlaksana proses belajar mengajar dengan baik sesuai dengan pendidikan yang diharapkan.

Untuk mengetahui lebih jauh mengenai keadaan guru di MTs GUPPI Rannaloe Kecamatan Bungaya Kabupaten Gowa dapat dilihat pada table I. 


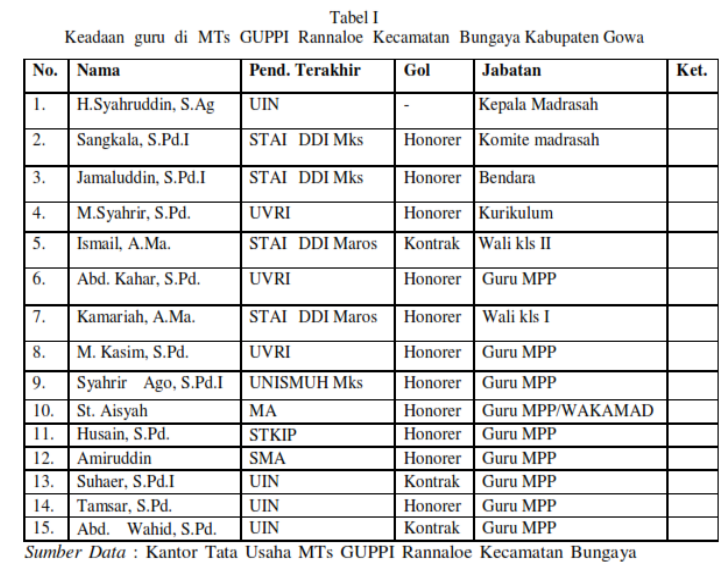
Kabupaten Gowa

Dari tabel I dilihat bahwa mengenai keadaan guru yang ada di MTs GUPPI Rannaloe rata-rata sudah menempuh pendidikan tinggi, hal ini memungkinkan bahwa kualitas dan kuantitas para guru yang ada di MTs Guppi Rannaloe mengalami kemajuan dalam bidang pendidikan. Tanggung jawab seorang guru bukan hanya mengajar akan tetapi bagaimana seorang guru mampu mendidik dan membimbing siswanya kearah yang lebih baik oleh karena itu diperlukan pengetahuan serta wawasan yang luas sehingga betul-betul menjadi guru yang profesional.

\section{b) Keadaan siswa}

Siswa merupakan salah satu bagian yang tidak dapat dipisahkan dengan sekolah, sebab tanpa adanya warga belajar dalam hal ini siswa maka sekolah tersebut tidak dapat terlaksana dalam proses belajar mengajar. Demikian juga di Madrasah Tsanawiyah Rannaloe Gowa yang sangat memegang peranan penting dalam memajukan dan mengembangkan Madrasah tersebut. Untuk mengetahui lebih lanjut tentang keadaan Madrasah
Tsanawiyah Rannaloe Gowa akan diuraikan dalam bentuk tabel II.

Tabel II

Keadaan siswa MTs GUPPI Rannaloe Kecamatan Bungaya Kabupaten Gowa

\begin{tabular}{|c|c|c|c|c|}
\hline \multirow{2}{*}{ No } & \multirow{2}{*}{ Kelas } & \multicolumn{2}{|c|}{ Jenis Kelamin } & \multirow{2}{*}{ Jumlah } \\
\hline & & LK & PR & \\
\hline 1 & VII & 13 & 17 & 30 \\
\hline 2 & VIII & 11 & 17 & 28 \\
\hline 3 & IX & 17 & 10 & 27 \\
\hline & JUMLAH & 41 & 44 & 85 \\
\hline
\end{tabular}
Gowa

Berdasarkan tabel II dapat diketahui bahwa jumlah siswa yang ada di Madrasah Tsanawiyah Rannaloe Gowa cukup banyak, hal ini memungkinkan sekolah tersebut bisalebih maju dan berkembang. Kehadiran MTs GUPPI Rannaloe membawa pengaruh yang sangat besar ditengah-tengah masyarakat yang mana MTs tersebut telah mendidik generasi pelanjut sebagai sosok insan yang mulia, yang berciri keagamaan sehingga banyak siswa yang memilih melanjutkan pendidikan di sekolah tersebut.

\section{Keadaan Sarana Dan Prasarana}

a) Keadaan Sarana

Sarana merupakan salah satu faktor yang sangat penting dalam lembaga pendidikan karena sebagai tempat untuk mengadakan proses belajar mengajar, dengan adanya sarana yang dimilki maka tujuan pencapaian pendidikan dapat terlaksana dengan baik. Untuk mengetahui keadaan sarana yang dimiliki MTs GUPPI 
Rannlaoe Kabupaten Gowa dapat digambarkan dalam table III.

Tabel III

Keadaan Sarana Mts GUPPI Rannaloe Kabupaten Gowa

\begin{tabular}{|l|l|l|l|l|l|}
\hline \multirow{2}{*}{ No } & \multirow{2}{*}{ Ruang } & \multirow{2}{*}{ Jumlah } & \multicolumn{2}{|l|}{ Keadaan } & \multirow{2}{*}{ Ket } \\
\cline { 4 - 5 } & & & Baik & Rusak & \\
\hline 1 & Ruang belajar & 3 lokal & Baik & - & \\
2 & Ruang kantor & 1 lokal & Baik & - & \\
3 & Ruang perpustakaan & 1 lokal & Baik & - & \\
4 & Mesjid & 1 buah & Baik & - & \\
5 & Kamar mandi/WC & 1 buah & Baik & - & \\
6 & Ruang komputer & 1 buah & Baik & - & \\
7 & Rumah pimpinan & 1 lokal & Baik & - & \\
& & & & & \\
\hline
\end{tabular}

Sumber data: Kantor Tata Usaha MTs GUPPI Rannaloe

Kecamatan Bungaya Kabupaten Gowa

Berdasarkan tabel III, dapat dilihat mengenai sarana yang dimiliki MTs GUPPI Rannaloe Kabupaten Gowa. Dengan sarana tersebut memungkinkan terjadinya proses belajar mengajar dengan baik serta kelengkapan sarana yang dimiliki maka siswa yang berada di sekitar sekolah terdorong hatinya untuk sekolah.

\section{b) Keadaan Prasarana}

Selain sarana yang dimiliki MTs GUPPI Rannaloe juga prasarana sebagai penunjang atau pelengkap dari sarana tersebut. Prasarana bertujuan untuk melengkapi hal-hal yang terkait dengan sarana. Untuk mengetahui keadaan prasarana yang dimiliki oleh MTs GUPPI Rannaloe dapat dilihat dari tabel IV.

\section{Berdasarkan tabel IV dapat \\ Keadaan Prasarana Mts GUPPI Rannaloe \\ Kecamatan Bungaya Kabupaten Gowa}

\begin{tabular}{|l|l|l|l|l|l|}
\hline No & Ruang & Jumlah & \multicolumn{2}{|l|}{ Keadaan } & \multirow{2}{*}{ Ket } \\
\cline { 4 - 5 } & & & Baik & Rusak & \\
\hline 1 & Meja kepala sekolah & 1 buah & Baik & - & \\
2 & Kursi kepala sekolah & 1 buah & Baik & - & \\
3 & Meja guru & 15 buah & Baik & - & \\
4 & Kursi guru & 15 buah & Baik & - & \\
5 & Meja belajar & 108 buah & Baik & - & \\
6 & Kursi belajar & 216 buah & Baik & - & \\
7 & Lemari kepala sekolah & 1 buah & Baik & - & \\
8 & Lemari guru & 3 buah & Baik & & \\
\hline
\end{tabular}

Kecamatan Bungaya Kabupaten Gowa diketahui mengenai keadaan prasarana yang dimiliki oleh MTs GUPPI Rannaloe. Sarana dan prasarana adalah dua hal yang tidak dapat dipisahkan karena mempunyai fungsi dan tujuan yang sama yaitu saling melengkapi yang satu engan yang lainnya, kelengkapan tersebut sangat mempengaruhi proses belajar mengajar yang merupakan bagian dari kebutuhan yang paling mendasar.

\section{Hasil Penilaian Tes Lisan \\ Pengucapan Kosa Kata Bahasa Arab Siswa Kelas VIII Madrasah Tsanawiyah Guppi Rannaloe Gowa}

\begin{tabular}{|c|c|c|c|}
\hline No. & Nama & Nilai & Ket \\
\hline 1 & Siti Masitah & 6 & \\
\hline 2 & Jurmiati & 6 & \\
\hline 3 & Hasnawati & 7 & \\
\hline 4 & Nur Hijrah & 8 & \\
\hline 5 & Husniah & 7 & \\
\hline 6 & Nur Ihwani & 5 & \\
\hline 7 & Mustiqomah & 5 & \\
\hline 8 & Nur Azizah & 6 & \\
\hline 9 & Siti Mu'asyarah & 7 & \\
\hline 10 & Siti Fatimah Nur Insani & 4 & \\
\hline 11 & Siti Aminah & 5 & \\
\hline 12 & Nurkhalisah & 6 & \\
\hline 13 & Marham & 6 & \\
\hline 14 & Nur Hanisa & 6 & \\
\hline 15 & Aldi Sahjum & 6 & \\
\hline 16 & Hayyul Hasnul & 7 & \\
\hline 17 & Isdar Alam & 6 & \\
\hline 18 & Muhammad Nurdin & 6 & \\
\hline 19 & Muhammad Firman & 6 & \\
\hline 20 & Amirullah & 8 & \\
\hline 21 & Muhammad Ismar & 7 & \\
\hline 22 & Amirullah HS & 8 & \\
\hline 23 & Ahmad Nasir & 7 & \\
\hline 24 & Muhamad Aswar & 5 & \\
\hline 25 & Ibrahim Sahnur & 6 & \\
\hline 26 & Khaerunnisa & 6 & \\
\hline 27 & Husnaini & 6 & \\
\hline 28 & Nur Ismah & 6 & \\
\hline
\end{tabular}

Dari hasil penelitian tabel di atas dapat disimpulkan bahwa kemampuan pengucapan kosa kata Bahasa Arab 
siswa kelas VIII Madrasah Tsanawiyah Guppi Rannaloe Gowa masih kurang dan belum lancar disebabkan oleh minimnya pengetahuan siswa terhadapa mata pelajaran bahasa arab dan penguasaan kosa kata bahasa arab itu sendiri.

\section{Upaya Yang Dilakukan Oleh Guru} Dalam Membantu Siswa Pada Pengucapan Kosa Kata Bahasa Arab Siswa Kelas VIII Madrasah Tsanawiyah Guppi Rannaloe Gowa

Dalam upaya yang ditempuh oleh guru untuk membantu siswa dalam penguasaan pengucapan kosa kata bahasa Arab antara lain memberikan tugas kepada siswa setiap hari untuk menghafalkan kosa kata bahasa arab minimal 10, mengarahkan siswa untuk mengucapakan kosa kata dengan berulang-ulang hingga mereka mampu mengucapkannya dengan baik dan benar, dan memberikan permainan-permainan edukasi dalam pembelajaran bahasa arab sehingga siswa terlatih untuk mengucapkan kosa kata bahasa arab.

\section{PENUTUP}

Kemampuan pengucapan Bahasa Arab siswa kelas VIII Madrasah Tsanawiyah Guppi Rannaloe Gowa masih di bawah rata-rata dikarenakan minimnya pengetahuan bahasa Arab di kalangan siswa itu sendiri, hal ini disebabkan oleh karena kebanyakan dari mereka berasal dari SD yang belum mengenal bahasa Arab sama sekali dan belum pernah mempelajarinya. Di samping itu, ada juga yang berasal Madrasah Ibtidaiyyah, namun tidak semua dari mereka mampu mengucapkan kosakata (mufradat) bahasa Arab secara baik dan benar. Adapun upaya yang dilakukan oleh guru dalam membantu pengucapan Bahasa Arab siswa kelas VIII Madrasah Tsanawiyah Guppi Rannaloe Gowa yakni memberikan minimal 10 kasa kata untuk di hafal, dan juga mengarahkan siswa mengucapkan kosa kata tersebut secara berulang-ulang higga mampu mengucapkannya dengan baik dan benar, dan juga melatih siswa mengucapkan kosa kata Bahasa Arab dengan permanan-permainan yang edukatif.

\section{DAFTAR PUSTAKA}

Alwi, Hasan, dkk. 2000. Tata Bahasa Baku Bahasa Indonesia. Jakarta : Balai Pustaka

Anggota IKAPI. 2008. Pedoman Umum Ejaan Bahasa Indonesia yang Disempurnakan/ Disalin dari Pusat Pembinaan dan Pengembangan Bahasa Departemen Pendidikan dan Kebudayaan Republik Indonesia. Bandung : CV Pustaka Setia

Gorys Keraf. 1994. Komposisi. Jakarta : Ikrar Mandiriabadi

Hadari Nawawi. 1993. Metode Penelitian Bidang Sosial. 
Yogyakarta : Gadjah Mada

University Press

Muhammad Rajab. 2008. Pentingnya Pembelajaran Bahasa Arab. Malang

Nailul Falah. 2002. Kemampuan Berbahasa Arab Mahasiswa IAIN Sunan Kalijaga Jogjakarta Ditinjau dari Sikap terhadap bahasa Arab dan Motivasi Belajar Mahasiswa.

Pei, Mario. 1971. Kisah dari Pada Bahasa. Terjemahan oleh Nugroho Notosusanto. Jakarta : Bhara bata

Proyek Peningkatan Prasarana dan Sarana Perguruan Tinggi Agama/ IAIN Jakrta. 1990. "Evaluasi Hasil Penelitian IAIN". Jakarta

Sardiman. 2007. Interaksi dan Motivasi Belajar mengajar. Jakarta : Rajawali Pers

Susanto. 2001. Program SPSS Versi 10,10. Jakarta : Gramedia

Hasbullah. 2006. Otonomi Pendidikan, Jakarta: PT Raja Grafindo. 
